Portland State University

PDXScholar

\title{
Spatial and morphological change of Eliot Glacier, Mount Hood, Oregon
}

Keith Michael Jackson

Portland State University

Follow this and additional works at: https://pdxscholar.library.pdx.edu/open_access_etds

Part of the Geography Commons

Let us know how access to this document benefits you.

\section{Recommended Citation}

Jackson, Keith Michael, "Spatial and morphological change of Eliot Glacier, Mount Hood, Oregon" (2007). Dissertations and Theses. Paper 4126.

https://doi.org/10.15760/etd.6010

This Thesis is brought to you for free and open access. It has been accepted for inclusion in Dissertations and Theses by an authorized administrator of PDXScholar. Please contact us if we can make this document more accessible: pdxscholar@pdx.edu. 


\section{THESIS APPROVAL}

The abstract and thesis of Keith Michael Jackson for the Master of Science in

Geography were presented February 9, 2007, and accepted by the thesis committee and the department.

COMMITTEE APPROVALS:

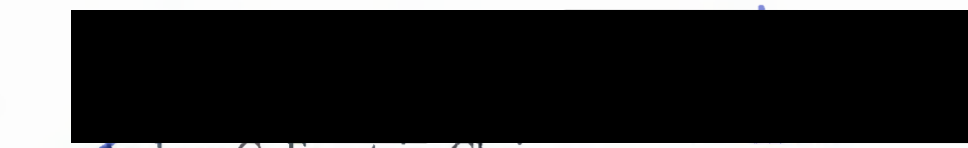

Andrew G. Fountain, Chair

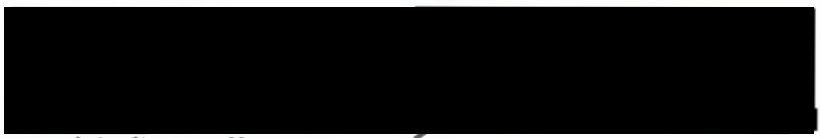

Keith S. Hadley

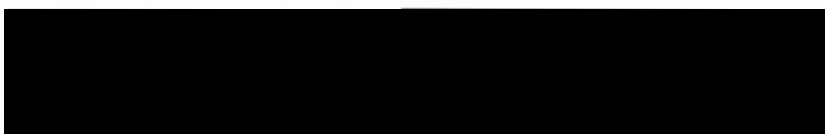

Martin D. Lafrenz

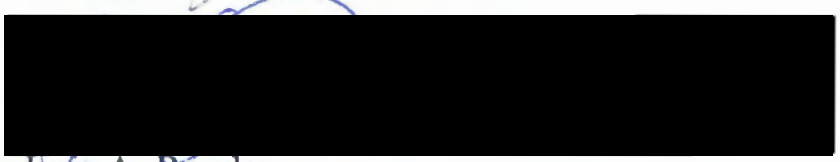

Lufs A. Ruedas

Representative of the Office of Graduate Studies

DEPARTMENT APPROVAL:

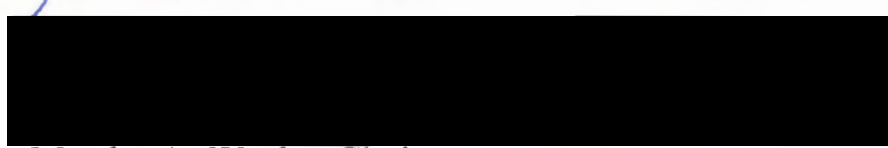

Martha A. Works, Chair

Department of Geography 


\begin{abstract}
An abstract of the thesis of Keith Michael Jackson for the Master of Science in Geography presented February 9, 2007.
\end{abstract}

Title: Spatial and Morphological Change of Eliot Glacier, Mount Hood, Oregon.

Eliot Glacier is a small $\left(1.6 \mathrm{~km}^{2}\right)$, relatively well-studied glacier on Mount Hood, Oregon. Since 1901, glacier area decreased from $2.03 \pm 0.16 \mathrm{~km}^{2}$ to $1.64 \pm$ $0.05 \mathrm{~km}^{2}$ by 2004 , a loss of $19 \%$, and the terminus retreated about $600 \mathrm{~m}$. Mount Hood's glaciers as a whole have lost $34 \%$ of their area. During the first part of the $20^{\text {th }}$ century the glacier thinned and retreated, then thickened and advanced between the 1940 s and 1960 s because of cooler temperatures and increased winter precipitation and has since accelerated its retreat, averaging about $1.0 \mathrm{~m} \mathrm{a}^{-1}$ thinning and a $20 \mathrm{~m} \mathrm{a}^{-1}$ retreat rate by 2004 . Surface velocities at a transverse profile reflect ice thickness over time, reaching a low of $1.4 \mathrm{~m} \mathrm{a}^{-1}$ in 1949 before increasing to $6.9 \pm 1.7 \mathrm{~m} \mathrm{a}^{-1}$ from the $1960 \mathrm{~s}$ to the $1980 \mathrm{~s}$. Velocities have since slowed to about $2.3 \mathrm{~m} \mathrm{a}^{-1}$, about the 1940 speed.

While the glacier response reflects the behavior of other glaciers on Mount Hood and the Pacific Northwest, its magnitude of retreat is much less. I hypothesize that the rock debris covering the ablation zone reduces Eliot Glacier's sensitivity to global warming and slows its retreat rate compared to other glaciers on Mount Hood. A continuity model of debris thickness shows the rate of debris thickening down 
glacier is roughly constant at about $5 \mathrm{~mm} \mathrm{a}^{-1}$ and is a result of the compensating effects of strain thickening and debris melt out from the ice. 
SPATIAL AND MORPHOLOGICAL CHANGE OF ELIOT GLACIER, MOUNT HOOD, OREGON

by

KEITH MICHAEL JACKSON

A thesis submitted in partial fulfillment of the requirements for the degree of

\author{
MASTER OF SCIENCE \\ in \\ GEOGRAPHY
}

Portland State University

2007 


\section{ACKNOWLEDGMENTS}

I would like to initially thank my advisor, Andrew G. Fountain, for his guidance and advice. I am grateful to him for sharing his vast knowledge of glaciology and Earth science, and for his encouragement and sense of humor. Additionally, conversations with committee members Keith S. Hadley and Martin D. Lafrenz were invaluable in encouraging me to examine the geomorphology of Mount Hood with wider eyes. I would also like to thank them and Luis A. Ruedas for their insightful comments that helped improve this thesis.

Many people assisted me with fieldwork, and I especially thank Rhonda Robb for her efforts. Additionally, I want to thank Hassan Basagic, Mike Boeder, Heath Brackett, Gretchen Gebhardt, Matt Hoffman, Shaun Marcott, and Thomas Nylen. Without your assistance, none of this would have been possible, and I am grateful to you all. I thank Rickard Pettersson for taking the time out of his busy schedule to come to Oregon and lead our GPR efforts. Conversations with Robert Schlichting helped formulate ideas and methods that benefited this thesis greatly, and I thank him for that. The Department of Geology donated survey equipment, of which I am immensely grateful. In addition to fieldwork assistance, Peter Sniffen provided valuable insight into an early draft of this thesis, and I am very appreciative of this. Finally, I thank Oliver for being at my side and making this project much more enjoyable than it otherwise would have been. Whether hopping from boulder to boulder on the glacier, or lying beside me on the couch waiting for me to put aside the computer, he was always there to put a smile on my face. 
This project was supported by two grants from the Geological Society of America, and by grants from the Mazamas Research Committee and Sigma Xi. Additionally, use of the historic Cloud Cap Inn was invaluable, and I thank Bill Pattison and the Crag Rats for their efforts and encouragement. 
ACKNOWLEDGMENTS.

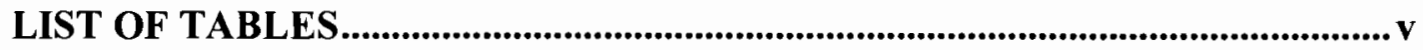

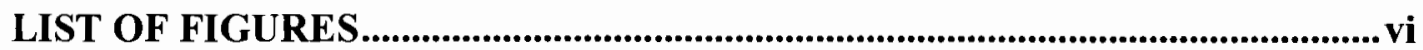

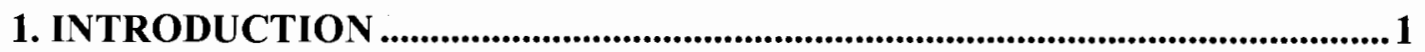

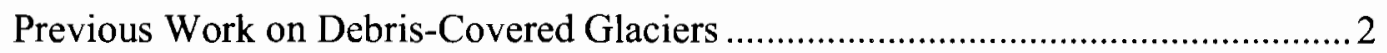

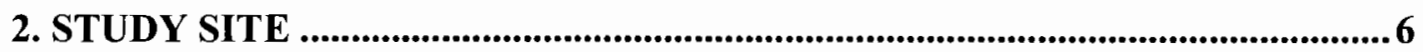

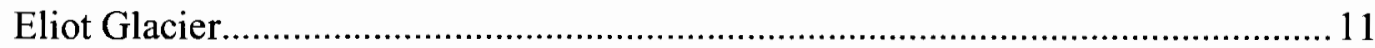

Previous Studies on Eliot Glacier...................................................................... 14

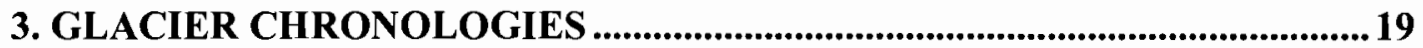

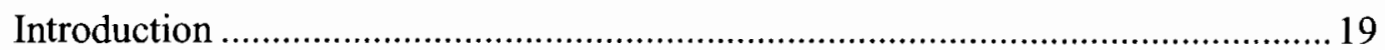

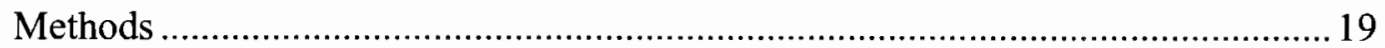

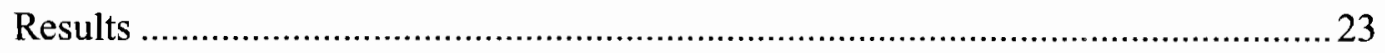

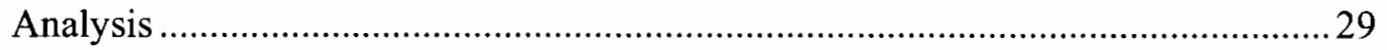

4. ABLATION AND DEBRIS THICKNESS .............................................................

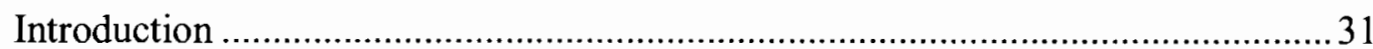

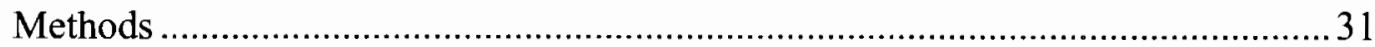

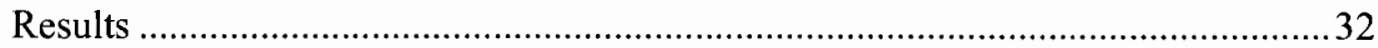

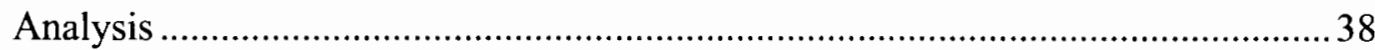

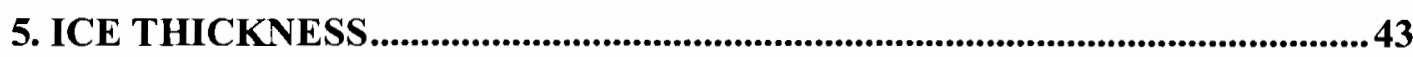

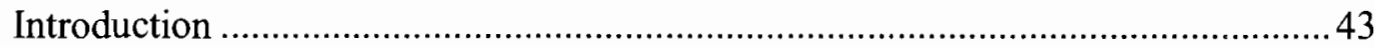

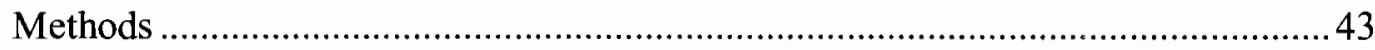

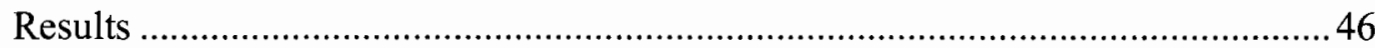

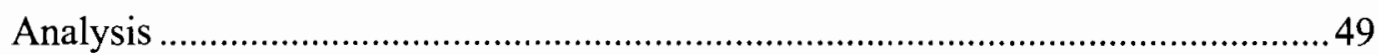

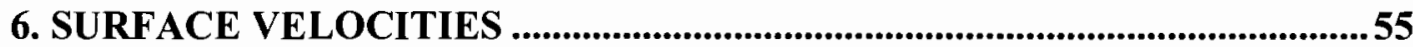

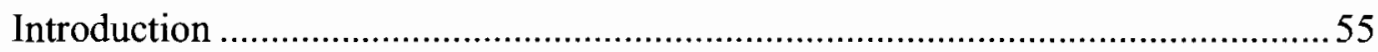

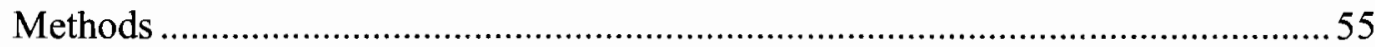

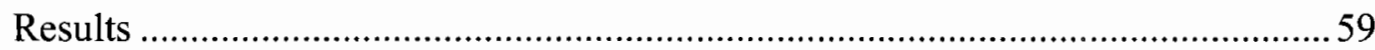

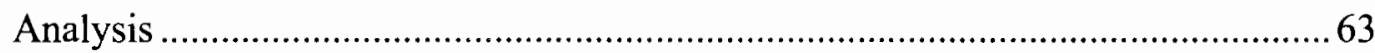

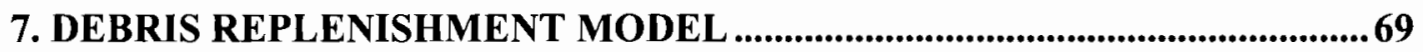

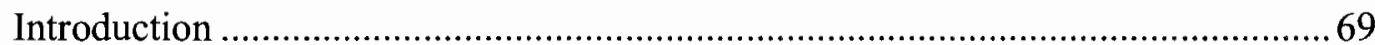

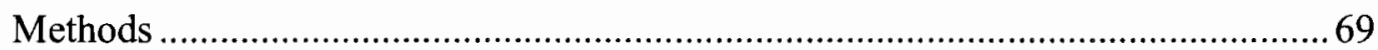

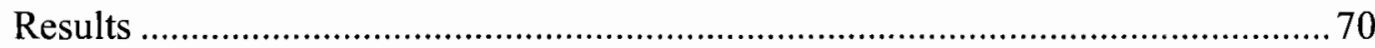

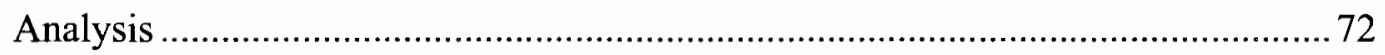

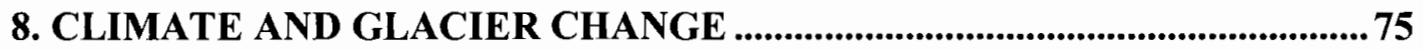


iv

Introduction and Methods...................................................................... 75

Results and Analysis.................................................................... 75

9. DISCUSSION AND CONCLUSIONS.................................................................. 83

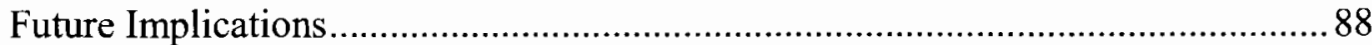

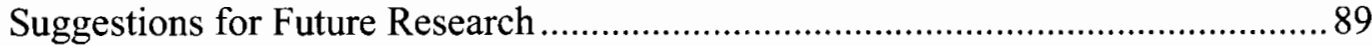

10. REFERENCES CITED.......................................................................................91

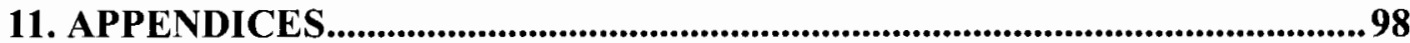

Appendix A. Glacier areas with root mean square errors (RMSE) for georeferenced aerial photographs and associated areal errors. Source key: USFS-United States Forest Service; USGS-United States Geological Survey; OGS-Oregon Geospatial Data Clearinghouse.

Appendix B. Four H.F. Reid photographs (courtesy Mazamas, Portland, Oregon) used to estimate glacier surface elevation in 1901. All photographs were taken on July 23, 1901 .

Appendix C. Compilation of debris cover thickness data. Coordinates are UTM

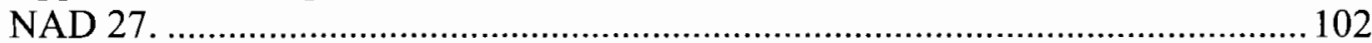

Appendix D. Compilation of survey data for elevation profiles........................ 104 Appendix E. Compilation of GPR data presented in Figure 23........................ 106 Appendix F. Compilation of data for velocity surveys. Easting and northing values

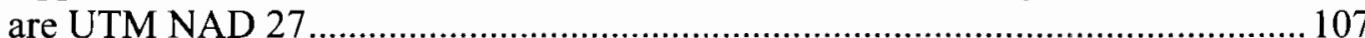




\section{LIST OF TABLES}

Table 1. Previous studies on Eliot Glacier. 16

Table 2. Data sources for glacier chronologies on Mount Hood. COL-Color Aerial Photograph; B\&W-Black \& White Aerial Photograph; DOQ-Digital Orthophotograph Quadrangle; OBL-Oblique Aerial Photograph; TOPO-Topographic Map; GRDTerrestrial Ground Photograph; USFS-United States Forest Service; USGS-United States Geological Survey; OGS-Oregon Geospatial Data Clearinghouse.

Table 3. Data sources for Collier Glacier chronology. Key: B\&W-Black \& White Aerial Photograph; DOQ-Digital Orthophotograph Quadrangle; TOPO-Topographic Map; GRD-Terrestrial Ground Photograph; POLY-Polygon digitized in publication; USFS-United States Forest Service; USGS-United States Geological Survey; OGSOregon Geospatial Data Clearinghouse

Table 4. Areas and terminus retreats for seven Mount Hood glaciers in this thesis and Collier Glacier, North Sister, Oregon. Collier Glacier values are 1910 and 1994 rather than 1907 and 2004. Eliot Glacier value is 1901 rather than 1907

Table 5. Mount Hood's glaciers and the effect of aspect on glacier retreat. 30

Table 6. Annual and summer (6-week period = Aug 13 - Sept 24, 2004) ablation values with corresponding debris thicknesses. Annual values are extrapolated from measurements over a 350-day period. A washout occurred around stake 6 during a rainstorm and reduced the debris cover from 51.5 to $40 \mathrm{~cm}$ between August 21 - 24, 2004.

Table 7. Ablation as a function of temperature and debris regression results.

$\mathrm{A}=$ ablation, $\mathrm{T}=$ temperature, $\mathrm{D}=$ debris thickness.

Table 8. Elevation profile reconstruction data 45

Table 9. Survey control points. Coordinates are UTM NAD 27.

Table 10. Errors for individual locations during survey on 07.28.2005.

Table 11. Displacement and velocity data for individual locations. ANNUAL $=350-$ day study period. SUMMER=6-week study period.

Table 12. Results of components in debris flux equation 


\section{LIST OF FIGURES}

Figure 1. Map of Oregon Cascades. White areas indicate late seasonal snowpack (NASA MODIS image, 04.26.2004).

Figure 2. Monthly precipitation and temperature averaged over Mount Hood. Data are mean monthly values averaged over 1900-2004 period. (From Daly et al., 1997). 9

Figure 3. Map of Eliot Glacier within the Hood River Watershed. 10

Figure 4. Land Use in the Hood River Watershed (Oregon Geospatial Data Clearinghouse, 2006). 10

Figure 5. Mount Hood's glaciers.

Figure 6. (a) Major debris sources of Eliot Glacier. (b) Photograph of the northeast side of Mount Hood, showing Eliot Glacier (photo Robert Schlichting, 2001). Yellow line indicates terminus in 2001 .

Figure 7. Locations of A and B profiles as well as selected terminus positions. Mazamas discontinued measuring the A-Profile after 1968.

Figure 8. Collier Glacier, 1994. Glacier outline indicated in yellow, and two ice/snow bodies not included in analysis marked with (1) and (2). Base image is 1994 DOQ..23

Figure 9. Glacier area over time on Mt. Hood and Collier Glacier (a) and same values normalized (b). Note: Collier Glacier errors are unknown (McDonald, 1995). 26

Figure 10. Map of glacier change since early 20th century on (a) Mt. Hood and (b) retreat of Collier Glacier over similar timespan.

Figure 11. July 23, 1901 photograph (taken by Reid) on left (Mazamas reference \# p17), July 22, 2005 photograph on right. The area to the west of the headwall (a), the large cliff-face of Cooper Spur (b), and two large bedrock humps have been exposed just down-glacier of the current ELA (c).

Figure 12. September 15, 1935 photograph (Gilardi) on left (Mazamas reference \# p16), July 22, 2005 photograph on right. Terminus position traced on 1935 photo and superimposed on 2005 image to illustrate magnitude of thinning and retreat since 1935. Current terminus labeled in light blue on right image.

Figure 13. Measuring a stake for ablation (timer photo by author) 
Figure 14. Longitudinal profile of debris thickness (terminus is approximately the farthest downglacier point). The trendline is a 2 nd order polynomial. $t=$ Debris thickness, $\mathrm{d}=$ Distance downglacier.

Figure 15. Debris thicknesses of Eliot Glacier. The measurement sites are a combination of my measurements and those of Granshaw and others in 2001. Map was created in ArcGIS/Spatial Analyst software using an inverse distance weighting scheme.

Figure 16. Summer and annual ablation levels-summer ablation accounts for an average of $41 \%$ of annual ablation. The six-week summer study period was August 13 - September 24, 2004.

Figure 17. (a) Summer ablation rates with increasing debris thickness. The major outlier in the center is stake 6, where the washout occurred. (b) Annual ablation rates and increasing debris thickness. The trendlines are exponential lines, a=ablation, $\mathrm{t}=$ debris thickness.

Figure 18. (a) Summer ablation rates and distance downglacier, (b) annual ablation rates and distance downglacier from stake 12. The trendlines are exponential lines, $\mathrm{a}=$ ablation, $\mathrm{t}=$ debris thickness.

Figure 19. (a) Stake 12, ablation as a function of degree days, (b) Stake 12, cumulative ablation as a function of cumulative degree days; (c) Stake 7, ablation as a function of degree days, (d) Stake 7, cumulative ablation as a function of cumulative degree days.

Figure 20. Ablation rates from this study, Lundstrom (1992) at Eliot Glacier, and Kayastha et al. (2000) at the Khumbu Glacier, Nepal, in relation to debris thickness. 42

Figure 21. Locations of A and B-profiles

Figure 22. Elevation profiles originally surveyed by Mazamas. Error bars represent 1 $m$ error in both directions (up and down) and are nearly encompassed by the size of the dots

Figure 23. Inverse distance weighting extrapolation of ice depths. Lateral margins are assumed to be zero ice thickness.

Figure 24. Longitudinal profile along the glacier's centerline of flow interpolated from the GPR with stakes labeled along the glacier surface. Vertical exaggeration is about 2:1.

Figure 25. B-profile with glacier base from inverse-distance weighted (IDW) map (Figure 23). The elevation of the glacier bottom was estimated by collecting depths along IDW graphic at $20 \mathrm{~m}$ intervals along the profile. 
Figure 26. 1956 oblique aerial photograph of Eliot Glacier showing the kinematic wave that resulted from the decrease in temperatures and increase in accumulation season precipitation in the early 1940s (H. Ackroyd photo, courtesy Mazamas).

Figure 27. Ice thickness with time. 1901 thickness is estimated from four H.F. Reid photographs. From: Mazamas surveys and this study (2005).

Figure 28. GPR image based on six profile lines. Numbers refer to profiles shown in (Figure 29).

Figure 29. Six GPR profiles with nearest cardinal directions labeled. Yellow arrows indicate bottom of the glacier. Red arrows indicate possible internal reflection "layers" on profiles 2,3 , and 4 .

Figure 30. Map showing control points, survey points, and location of the total station theodolite.

Figure 31. Ground survey vectors multiplied by 5 and photogrammetric vectors divided by 3 to give 5 -year displacements.

Figure 32. Displacements at locations above active terminus during summer study period. Error bars represent survey uncertainties for total each displacement value. .63

Figure 33. Vertical displacements along centerline of flow. Positive displacement indicates emergence and negative displacement indicates submergence.

Figure 34. Annual (a) and summer (b) velocities, plotted against distance down-glacier along the central flowline. Errors for both surveys are encompassed by the size of the dots.

Figure 35. Annual speeds for ground and photogrammetric surveys. No photogrammetric measurements were made in the upper $300 \mathrm{~m}$ of the glacier. Error bars on the annual ground survey are encompassed by the size of the dots.

Figure 36. Surface speeds at the B-profile over time. Respective studies represent the following time spans: 1941-42 (Matthes and Phillips, 1943); 1946-52 (Mason, 1954); 1954-64 (Dodge, 1964); 1984-89 (Lundstrom, 1992); 1989-2004 (This thesis, photogrammetry); 2004-05 (This thesis, ground survey). Errors on studies prior to 1992 are unknown.

Figure 37. Debris replenishment values for each segment with the vertical strain and debris melt-out terms. Note: vertical errors are $20 \mathrm{~mm}$ for each segment.

Figure 38. Field measurements of debris cover (solid line/circle) plotted with model results. Original model results are the triangle/dashed line whereas adjusted model results (increase of $2 \mathrm{~m} \mathrm{a}^{-1}$ ) are the square/dashed line. 
Figure 39. (a) Five-year running average temperatures and (b) five-year running average precipitation values from 1900-2004. Summer season is defined as May 1 September 30 and winter season is defined as October 1 - April 30. Source: Oregon Climate Service.

Figure 40. (a) Eliot Glacier's area (dashed) over time compared to mean temperatures on Mount Hood; (b) Eliot Glacier's area (dashed) compared to winter precipitation. . 78

Figure 41. Ice thickness at the B-Profile (dashed line) compared to (a) temperature and

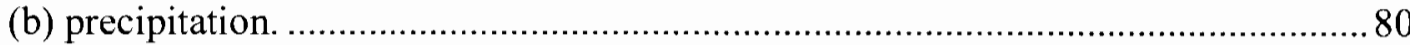

Figure 42. Ice thickness and surface velocity over time compared to 5-year running average temperature 


\section{INTRODUCTION}

Glaciers around the world have been indicators of recent climate change. Most of the glaciers around the world have followed a retreat/advance/retreat pattern since the "Little Ice Age," (LIA) a global cool period from about 700 years B.P. to 150 years B.P (Haeberli et al., 1998). The glaciers of the contiguous United States retreated until 1950 (Meier and Post, 1962) before advancing and retreating again at varying times between the 1970s and early 1990s (Dyurgerov and Meier, 1997). Glaciers on Mount Rainier retreated until the late 1950s, advanced through the early 1980s, and retreated again through the mid-1990s (Nylen, 2004). Between 1910 and 1994, the total glacier area loss on Mount Rainier was 18.5\% (Nylen, 2004), while Granshaw and Fountain (2006) measured areal loss in the North Cascades at 7\% between 1958 and 1998. Seven glaciers in the Sierra Nevada have lost an average of $50 \%$ during the last century (Basagic and Fountain, 2005) and glaciers in Glacier National Park lost an astounding 65\% from 1850 to 1979 (Hall and Fagre, 2003). The glaciers of the European Alps and Caucasus have lost about a third of their area (Meier et al., 2003).

Climate warming can directly affect glaciers through increased melt and decreased snowfall. Melting leads to higher stream flows, which alter local hydrology and regional water resources (Fountain and Tangborn, 1985; Fleming and Clarke, 2003). As glaciers shrink and disappear, late summer stream and reservoir levels will decline (Service, 2004). Understanding the role glaciers play in summer water regimes and the response of glaciers to climatic warming is an important component 
of alpine hydrology and ecology (Hall and Fagre, 2003). Additionally, mountain glaciers and small ice caps are responsible for one-third to one-half of sea-level rise since 1900 (Meier, 1984).

\section{Previous Work on Debris-Covered Glaciers}

Much of the research concerning alpine glaciers has focused on "clean" glaciers largely devoid of rock debris (Konrad and Humphrey, 2000). Consequently, little is known about the mass balance processes and effects of climate change on debris-covered glaciers. This lack of research is of concern because of the related hazards presented by debris-covered glaciers during the current period of global warming. Debris-covered glaciers are relatively common on the stratovolcanoes of the western United States, in the Rocky Mountains, the Hindu Kush-Himalaya region of central Asia, and the Andes of South America. Debris-covered glaciers also pose significant flood hazards in the Himalayas because their rapid recession creates unstable ice dam lakes (Fushimi et al., 1985; Reynolds, 1999; Richardson, 1968; Richardson and Reynolds, 2000).

Debris-covered glaciers may be a transitional phase between "clean" glaciers and "rock" glaciers (Nakawo et al., 2000). It should be noted that I use the term "rock glacier" to refer to glaciers that are ice-cored and have a surface debris layer that covers more than $90 \%$ of the glacier's surface (Konrad et al., 1999; Potter, 1972). This is in contrast to the periglacial rock glaciers that have been described in other works and are comprised of a rock/interstitial ice matrix of permafrost origins (Humlum, 1999). The knowledge gained from debris-covered glaciers like Eliot and 
their spatial and morphological changes may be applied to better understand other glaciers that are mantled in rock debris.

While the literature on debris-covered glaciers is small compared to "clean" glaciers, several studies are noteworthy. Konrad et al. (1999) measured flow velocities on Galena Creek Rock Glacier in the Absaroka Mountains of Wyoming that average 0 to $1 \mathrm{~m} \mathrm{a}^{-1}$. Additionally, rock glacier velocities have been measured to be $0.2 \mathrm{~m} \mathrm{a}^{-1}$ in Colorado (Outcalt and Benedict, 1965) and 0 to $0.72 \mathrm{~m} \mathrm{a}^{-1}$ in southeastern Yukon, Canada (Sloan and Dyke, 1998). The mass balance of the Galena Creek Rock Glacier is influenced by the spatial variation of debris thickness. In general, as surface debris thickens in the down-glacier direction the net ablation rate decreases downglacier. This contrasts with a typical "clean" valley glacier, where ablation increases downvalley. Pelto (2000) determined that annual ablation was reduced $25-30 \%$ for small debris-covered glaciers in the North Cascades of Washington.

Iwata et al. (2000) examined the relation between ice flow, ablation, and debris supply by comparing topographic maps made of lower Khumbu Glacier, flowing southwest from Mount Everest, in 1978 and 1995. They discovered that areas of high local relief and thin debris cover on the otherwise debris-covered ablation zone experienced increased ablation rates and thinning, mostly as a result of localized streams and ponds exposing ice. Kadota et al. (2000) determined that Khumbu Glacier was thinning at about $0.6 \mathrm{~m} \mathrm{a}^{-1}$ and that surface velocities were decreasing as a result. 
Research on the spatial fluctuations of debris-covered glaciers is lacking, as the boundaries of debris-covered and rock glaciers can be difficult to define. Two debris-covered glaciers in Washington that have been examined are the Mazama Glacier on Mount Baker, and the Carbon Glacier on Mount Rainier. Beyond the active terminus of the Mazama Glacier, remnant stagnant is found and may be from the LIA (Pelto, 2000). The Mazama Glacier has retreated the least from its LIA extent of all the glaciers on Mount Baker, which is attributable to its debris-covered terminus. The Carbon Glacier on Mount Rainier retreated almost half as much as the other glaciers on Mount Rainier (Nylen, 2004) and was the last glacier to begin receding following a mountain-wide glacial advance into the 1980s. It is likely that the spatial and morphological change patterns on Eliot Glacier will reflect those of the debriscovered glaciers on other Cascade stratovolcanoes.

I hypothesize that the glaciers of Mount Hood exhibit similar variations in area and response to climate variation but that the debris-covered Eliot (and Coe) Glacier exhibits less shrinkage as a result of the insulating effects of the debris and higher accumulation areas. This thesis is a case study of a debris-covered glacier and its response to climatic warming in comparison to other glaciers on Mount Hood and elsewhere. Specifically, 1 document the spatial change of Eliot Glacier since 1901 and place these results into the context of Mount Hood's six other glaciers as well as Collier Glacier on North Sister, Oregon. I also examine three interrelated morphological issues of debris-covered glaciers: (1) the changing surface topography (ice and debris) as a result of net ice loss; (2) the response in glacier flow speed to 
changes in morphology; and (3) estimate the rate of debris flux to the glacier surface. This thesis is structured to initially present the spatial change of Mount Hood's glaciers over the $20^{\text {th }}$ century, and then narrow in to Eliot Glacier's response to climate. Debris thickness, ablation rates, ice thickness, and surface velocities are examined, before presenting a model of debris thickness change over time. I then compare the climate record at Mount Hood to Eliot and the six other glaciers and finish with a discussion and conclusions chapter. 


\section{STUDY SITE}

Mount Hood is the northernmost volcanic peak in the Oregon Cascade Range and the highest point in the state at $3425 \mathrm{~m}$ (Figure 1). It dates to the middle and late Quaternary period $(\sim 730,000$ yr B.P.) when the volcano first formed (Sherrod and Smith, 1990). Almost $70 \%$ of the mountain is comprised of andesite flows, while the upper portion contains more dacite domes and pyroclastics (Wise, 1968). The most recent eruptive period (the Old Maid period) occurred ca. 200 years ago (Crandell, 1980), while the glaciers of the mountain were likely near their LIA extents.

Additional eruptive periods occurred between 1,500-1,800 years ago and 12,00015,000 years ago (Crandell, 1980).

During the Pleistocene $(\sim 1.8$ million years $\mathrm{BP} \sim 10,000$ years $\mathrm{BP})$ the Oregon Cascades may have been covered by glaciers creating a small ice cap (Porter et al., 1983). Scott (1977) inferred maximum glacial extents at Mount Jefferson to have occurred 20-25,000 years ago, comparable to those found on Mt. Rainier, Washington. Licciardi et al. (2004) identified two glacial advances in the Wallowas, one at approximately 21,000 years ago and the other at 17,000 years ago. Compared with other glacial maximums from the western United States, the Wallowas illustrate the influence of the Laurentide Ice Sheet on the regional climate. Precise dating of Pleistocene glacial advances on Mount Hood is currently lacking, but they most likely reflect the glacial history of the other glaciated areas of the Pacific Northwest. 


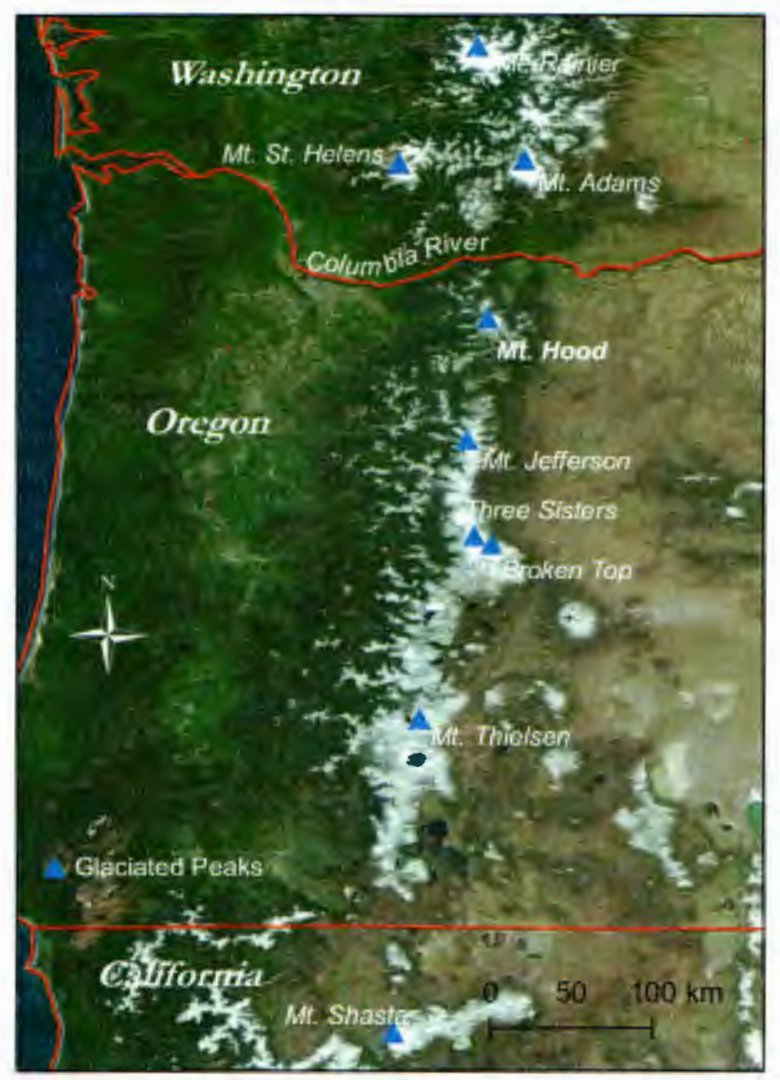

Figure 1. Map of Oregon Cascades. White areas indicate late seasonal snowpack (NASA MODIS image, 04.26.2004).

Holocene $(\sim 10,000$ years ago to the present) glacial fluctuations are better understood in Oregon. Lillquist (1989) identified LIA moraines on Mount Hood and possibly moraines dating to approximately $4,500-5,000$ years ago. LIA moraines have also been identified on Mount Jefferson (Scott, 1977), the Three Sisters (Marcott, 2005), Broken Top (Dethier, 1980; Marcott, 2005), and Mount Thielsen (Lafrenz, 2001). Other moraine sets downslope from the LIA moraines on the Three Sisters and Broken Top place glacial advances/stands at about 2,000 - 3,000 and 4,500 - 6,500 years ago. Another moraine set downslope of these pre-dates 7,700 years ago (Marcott, 2005). Kiver (1974) identified LIA moraines in the Wallowas as well as a 
morainal advance/stand at approximately 2,000 years ago (Prospect Lake). The moraines from the LIA and earlier dates indicate larger glaciers than presently exist. The Cascades are a major orographic barrier to the moist eastward-flowing Pacific air and create a maritime climate in western Oregon and a rain shadow to the east resulting in an arid climate in eastern Oregon (Dart and Johnson, 1981). Gridded surface meteorological data, acquired from the PRISM dataset (Oregon Climate Service, Corvallis, OR, Daly et al., 1997) show that the majority of the precipitation (over $80 \%$ ) that falls on Mount Hood occurs between October and April under much cooler temperatures (Figure 2). The average annual temperature since 1900 has been $2.0^{\circ} \mathrm{C}$ with the warmest year occurring in $1934\left(4.3^{\circ} \mathrm{C}\right)$ and the coolest year in 1903 $\left(-0.4^{\circ} \mathrm{C}\right)$. The average annual precipitation has been $134.1 \mathrm{~cm}$ with the driest year occurring in $1930(79.0 \mathrm{~cm})$ and the wettest year in $1996(217.4 \mathrm{~cm})$. Snow telemetry (SNOTEL) sites around Mount Hood (April 1, 2006 data) show a linear relationship between elevation and snow depth $\left(R^{2}=0.81\right)$ of $5 \mathrm{~cm}$ snow depth per $100 \mathrm{~m}$ elevation. Applying this relationship between snow depth and elevation on Mount Hood, during the 2005-2006 winter season, Eliot Glacier received approximately $25 \mathrm{~m}$ of snow near its terminus and as much as $51 \mathrm{~m}$ near the summit of the mountain. However, this is likely an overestimate because of wind redistribution of snow. 


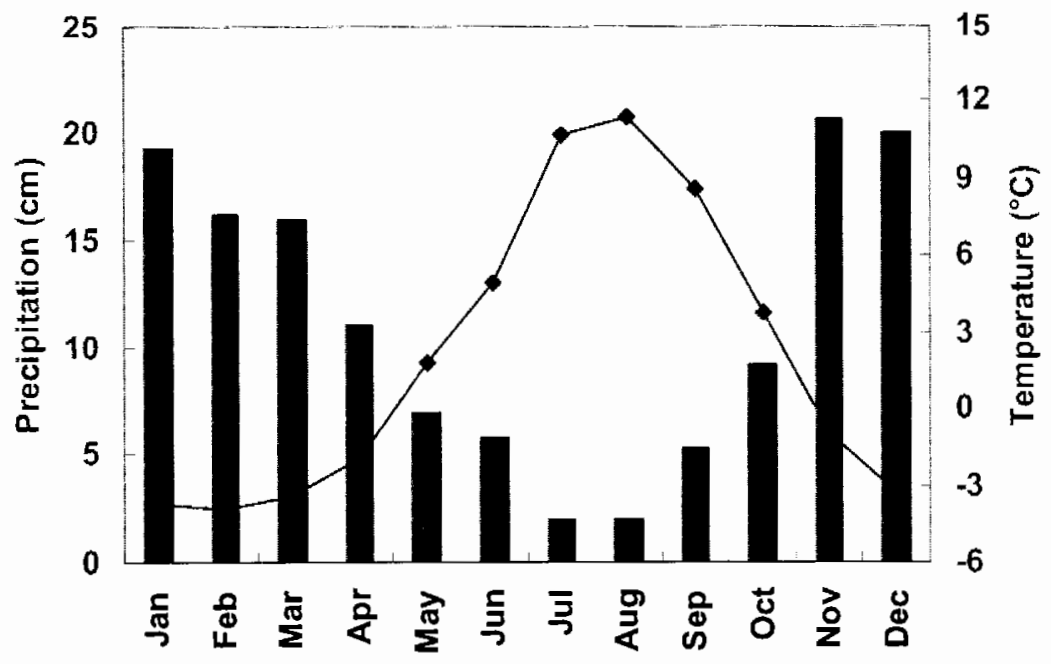

Figure 2. Monthly precipitation and temperature averaged over Mount Hood. Data are mean monthly values averaged over 1900-2004 period. (From Daly et al., 1997).

Eliot Glacier is drained by Eliot Creek, a tributary to the Middle Fork of the Hood River (Figure 3). Thirteen percent of the land use within the Hood River watershed is devoted to agriculture, second to forestry (Figure 4) and many commercial orchards depend in part on glacial meltwater for irrigation during summer months (Lundstrom, 1992). A majority of the water produced by Eliot Creek is diverted to a settling pond and then piped to the agricultural areas of the Hood River Valley. These agricultural businesses are directly dependent upon the water produced by the glaciers within the Hood River watershed (Milstein, 2006). 


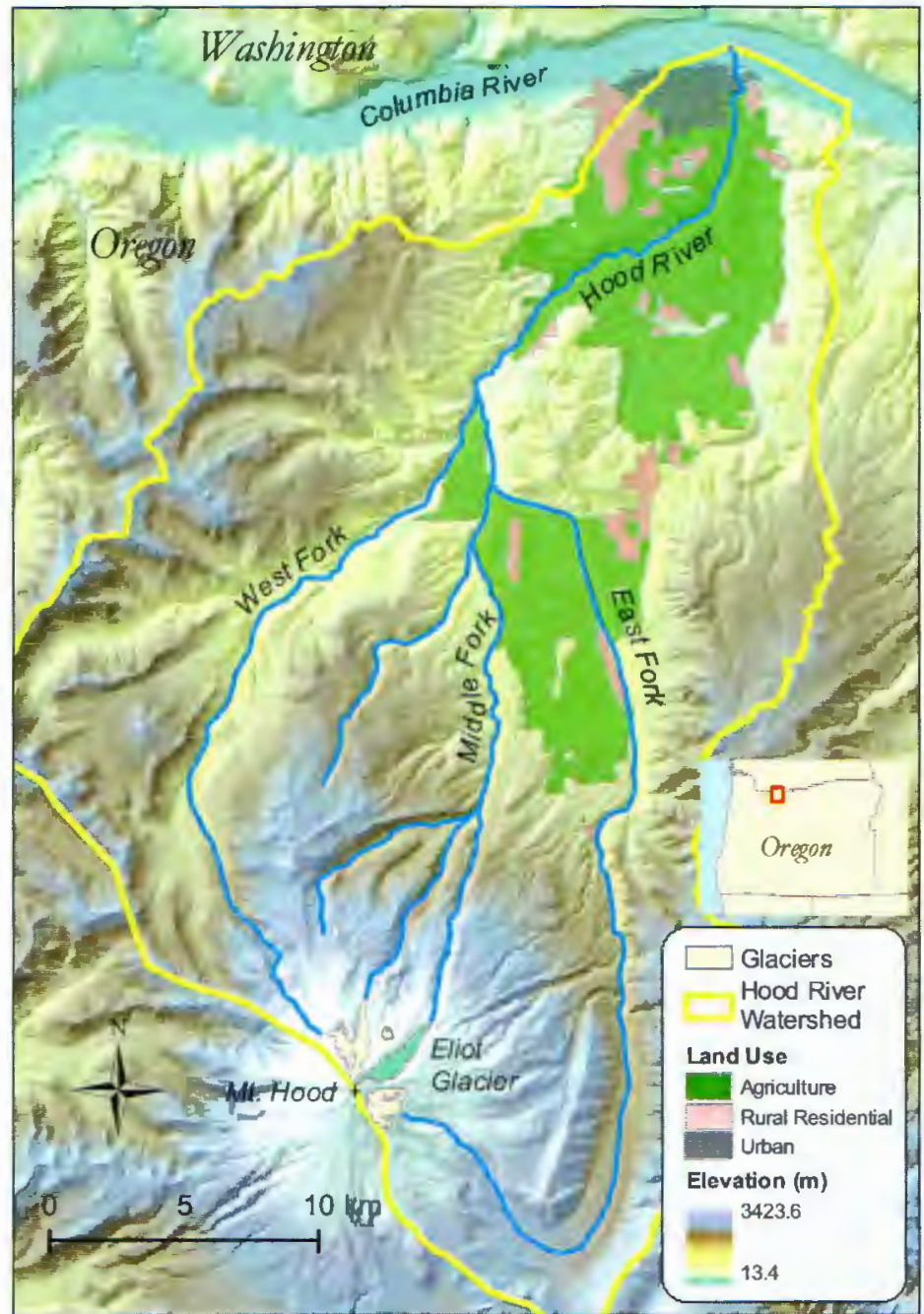

Figure 3. Map of Eliot Glacier within the Hood River Watershed.

\section{Land Use in the Hood River Watershed}

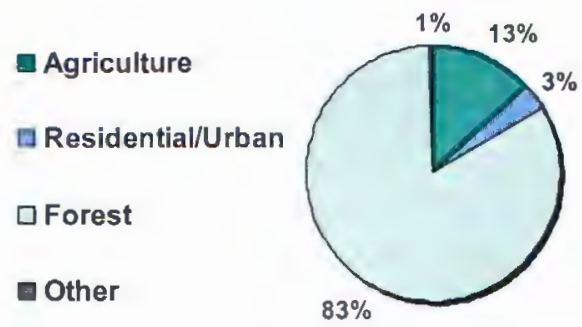

Figure 4. Land Use in the Hood River Watershed (Oregon Geospatial Data Clearinghouse, 2006) 


\section{Eliot Glacier}

Eliot Glacier is about $1.6 \mathrm{~km}^{2}$ in area, $3.6 \mathrm{~km}$ long and $800 \mathrm{~m}$ wide at its widest location (Figure 5). It spans an elevation range from $1920 \mathrm{~m}$ at the terminus to just over $3300 \mathrm{~m}$ near the summit of Mount Hood with a mean elevation of about 2365 m. Slope values range from $0^{\circ}$ to $69^{\circ}$, with a mean value of $21^{\circ}$. Aspects are predominantly north and east with a mean of $42.3^{\circ}$. The current equilibrium line altitude (ELA) is approximately $2400 \mathrm{~m}$. Eliot Glacier descends from a steep headwall of mechanically weak geothermally-altered rock, prone to occasional rock avalanches (Lundstrom, 1992). The adjacent ridge southeast of Eliot Glacier (Cooper Spur) is composed of block and ash flows and provides a debris source to the eastern portion of the glacier (Crandell, 1980) (Figure 6). The rock debris from these two areas is deposited on the accumulation zone of the glacier and becomes incorporated into the ice by subsequent snowfalls. The debris is transported englacially to the ablation zone where it emerges from the ice onto the surface about $850 \mathrm{~m}$ downglacier from the ELA (Figure 6) (Small, 1987). As a result, the lower portion of Eliot Glacier, about $27 \%$ of the total area, is covered with debris. The debris thickens with decreasing elevation with zero debris at $2120 \mathrm{~m}$ and over $1.5 \mathrm{~m}$ thick debris at the terminus (Lundstrom ,1992; Schlichting, unpublished). Eliot Glacier appears to be a midpoint on the spectrum between an entirely rock debris-covered glacier and a "clean" glacier. Debris cover acts as either and enhancer or inhibitor of melt on glaciers. Thin layers of debris $(<2 \mathrm{~cm})$ enhance melting, as a result of increased solar 
absorption compared to "clean" ice (Lundstrom 1992, Ostrem 1959, Kayastha et al. 2000). Thick layers of debris $(>2 \mathrm{~cm}$ ) insulate the ice and reduce melting (Lundstrom 1992, Nakawo and Young 1982).

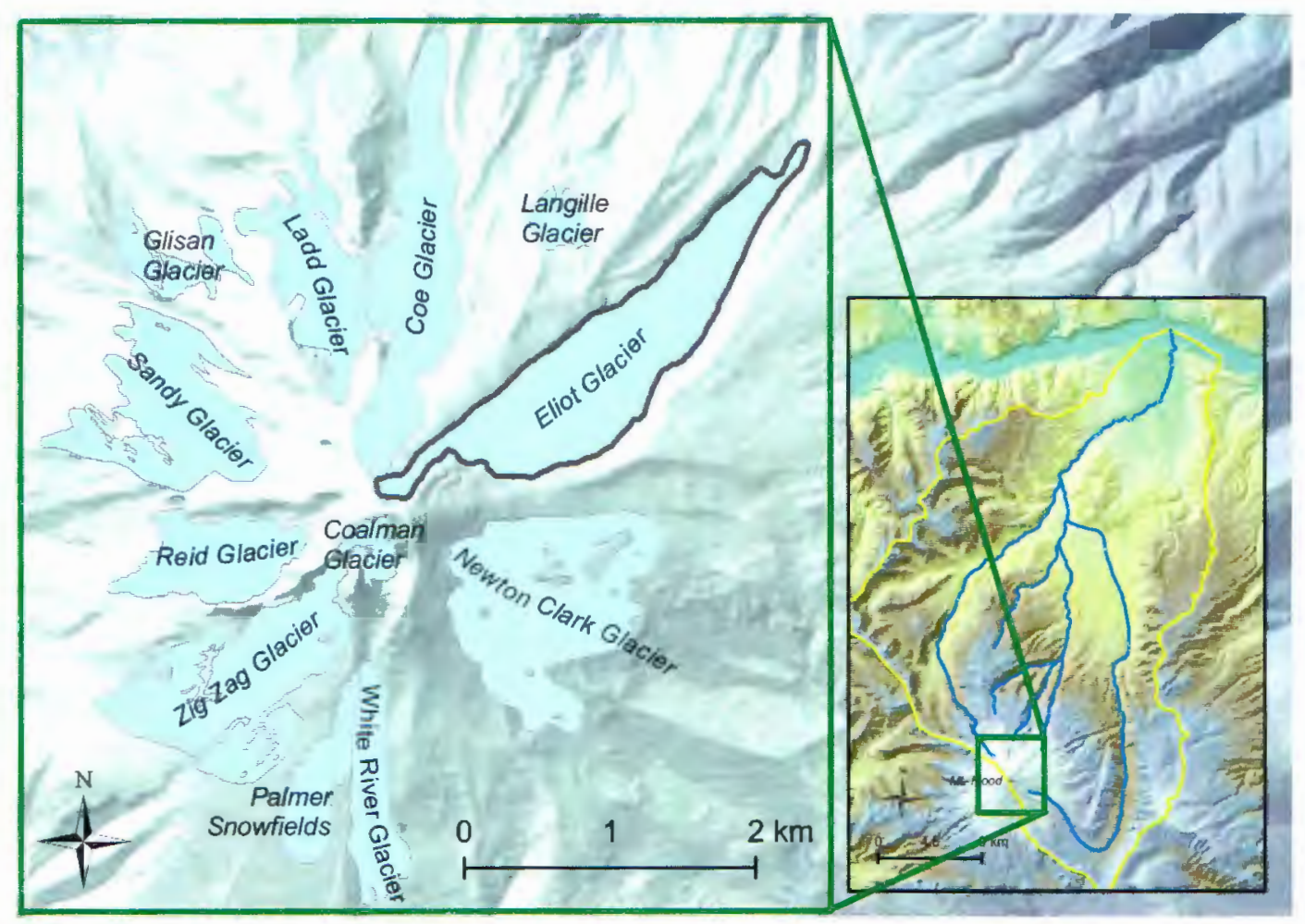

Figure 5. Mount Hood's glaciers. 

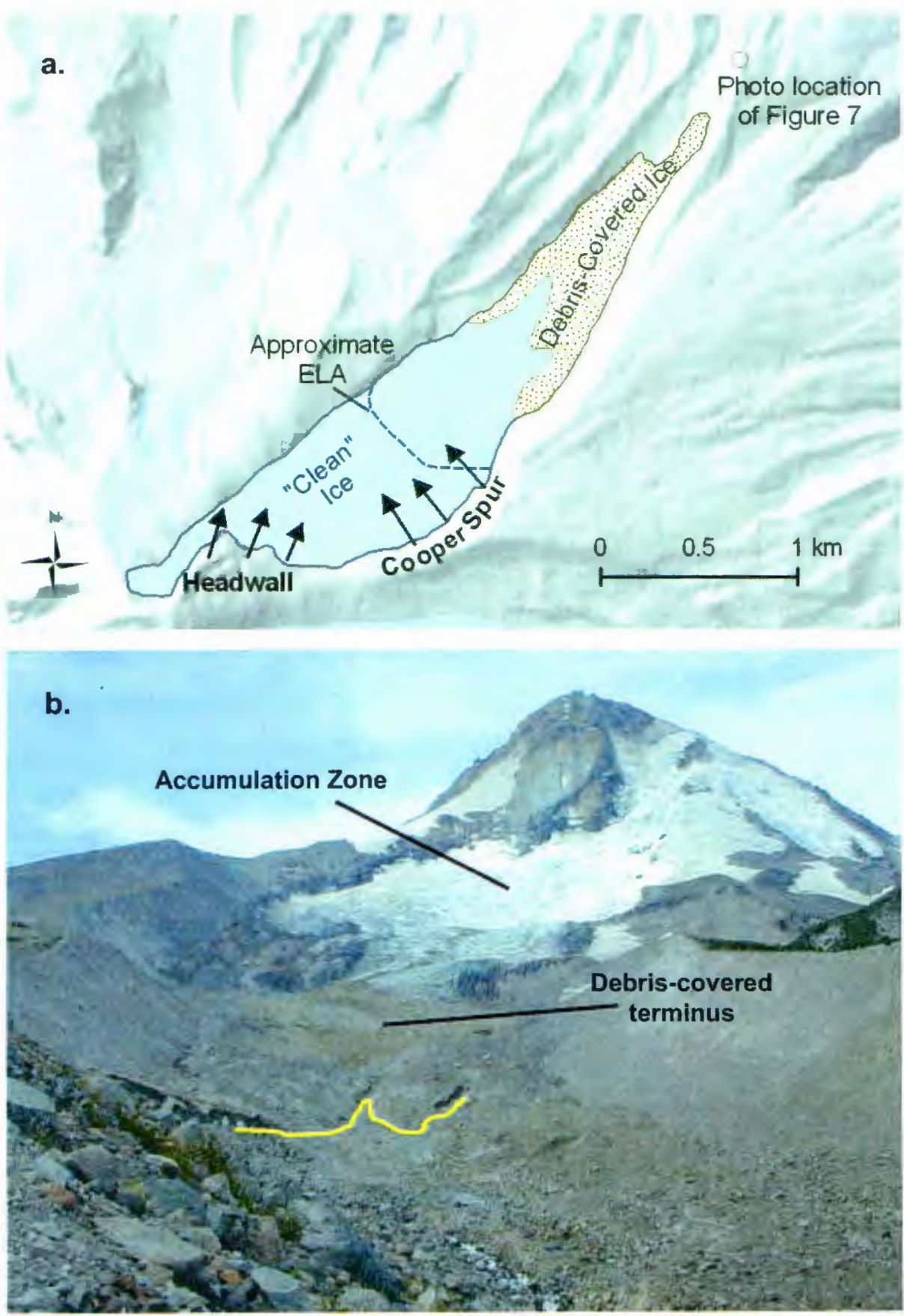

Figure 6. (a) Major debris sources of Eliot Glacier. (b) Photograph of the northeast side of Mount Hood, showing Eliot Glacier (photo Robert Schlichting, 2001). Yellow line indicates terminus in 2001. 
I chose Eliot Glacier because of its accessibility (30-minute walk from the Cloud Cap Saddle Campground trailhead, Forest Service Trail \#600) and its history of previous studies that provide more than a 100 year record of spatial and morphological change. The extensive record of study conducted by the Mazamas organization and then Lundstrom (1992) allows for a detailed examination of the morphological changes over the last century. My study area is the debris-covered portion of the glacier that can be examined in relative safety (few crevasses and headwall rockfall).

\section{Previous Studies on Eliot Glacier}

The first "discovery" of glaciers on Mount Hood is a matter of debate, however. Coleman (1877) credits the "discovery" of glaciers in Oregon to LieutenantColonel Gordon Granger, who visited the glaciers of Mount Hood in 1840. However, Arnold Hague's descriptions of Mount Hood's glaciers were the first to be published (King, 1871). In 1867, the U.S. Congress passed legislation funding the War Department to survey all lands east of California along the 40th parallel and named Clarence King the geologist in charge. King sent Hague north from San Francisco in August, 1870. Hague examined the glaciers on the south side of the mountain while climbing to the summit in early September. King (1871) is credited with the first "discovery" of glaciers in the American West, during his climb of Shastina (a parasitic volcanic cone on the western flank of Mount Shasta) on September 11, 1870. However, Hague "discovered" the glaciers of Mount Hood at some point between September 4, 1870 and September 18, 1870 (Babson, 1997), and may deserve credit for "discovering" glaciers in the western United States before King. 
Since the initial "discovery" of glaciers on Mount Hood, they have received much scientific attention (Table 1). Reid (1905) described several of the glaciers on Mount Hood, and the Mazamas Research Committee (mountaineering club) initiated studies on Eliot Glacier in 1925 (Marshall et al., 1925). Phillips $(1935 ; 1938)$ used the photographs by Reid in 1901 as a baseline for measuring terminus recession concluding the terminus had retreated $130 \mathrm{~m}$ between 1901 and 1938 . By 1946 the glacier retreated $50 \mathrm{~m}$ farther than 1938 (Lawrence, 1948). Conversely, the nearby White River Glacier, a "clean" glacier on the south side of the mountain, retreated 560 m between 1901 and 1946. Phillips (1938) attributed the large difference in recession to Eliot's debris cover and its "shady northeast slope." Between 1951 and 1958, the terminus retreated another $24 \mathrm{~m}$ (Handewith, 1959). Lillquist and Walker (2006) found that five of Mount Hood's glaciers experienced terminus retreat ranging from $62 \mathrm{~m}$ at Newton Clark Glacier to $1102 \mathrm{~m}$ at Ladd Glacier. 
Table 1. Previous studies on Eliot Glacier.

\begin{tabular}{|c|c|c|c|}
\hline YEAR & AUTHOR(S) & TITLE & STUDY \\
\hline 1905 & Reid & $\begin{array}{c}\text { The glaciers of Mt. Hood and Mt. } \\
\text { Adams }\end{array}$ & $\begin{array}{l}\text { General description and } \\
\text { velocities }\end{array}$ \\
\hline 1935 & Phillips & Recent changes in Hood's glaciers & Terminus fluctuations \\
\hline 1938 & Phillips & Our vanishing glaciers & Terminus fluctuations \\
\hline 1942 & Phillips & $\begin{array}{c}\text { Terminal speeds of some Cascade } \\
\text { Mountain glaciers }\end{array}$ & Velocities \\
\hline 1943 & $\begin{array}{l}\text { Matthes \& } \\
\text { Phillips }\end{array}$ & $\begin{array}{l}\text { Surface ablation and movement of } \\
\text { the ice on Eliot Glacier }\end{array}$ & $\begin{array}{l}\text { Topographic changes, } \\
\text { velocities, ablation rates }\end{array}$ \\
\hline 1948 & Lawrence & $\begin{array}{l}\text { Mt. Hood's latest eruption and } \\
\text { glacier advances }\end{array}$ & Terminus fluctuations \\
\hline 1954 & Mason & $\begin{array}{c}\text { Recent survey of Coe and Eliot } \\
\text { Glaciers }\end{array}$ & $\begin{array}{l}\text { Topographic changes, } \\
\text { velocities, ablation rates }\end{array}$ \\
\hline 1959 & Handewith & $\begin{array}{l}\text { Recent glacier variations on Mt. } \\
\text { Hood }\end{array}$ & $\begin{array}{l}\text { Terminus fluctuations, } \\
\text { topographic changes, } \\
\text { ablation rates }\end{array}$ \\
\hline 1964 & Dodge & $\begin{array}{l}\text { Recent measurements on the Eliot } \\
\text { Glacier }\end{array}$ & $\begin{array}{l}\text { Topographic changes, } \\
\text { velocities, ablation rates }\end{array}$ \\
\hline 1971 & Dodge & $\begin{array}{l}\text { The Eliot Glacier: new methods and } \\
\text { some interpretations }\end{array}$ & Ablation rates \\
\hline 1986 & $\begin{array}{l}\text { Dreidger \& } \\
\text { Kennard }\end{array}$ & $\begin{array}{l}\text { Ice volumes on Cascade Volcanoes- } \\
\text { Mount Rainier, Mout Hood, Three } \\
\text { Sisters, and Mount Shasta. }\end{array}$ & Ice thickness and volume \\
\hline 1987 & Dodge & Eliot Glacier: net mass balance & Ablation rates \\
\hline 1992 & Lundstrom & $\begin{array}{c}\text { The budget and effect of superglacial } \\
\text { debris on Eliot Glacier, Mount Hood, } \\
\text { Oregon }\end{array}$ & $\begin{array}{l}\text { Topographic changes, } \\
\text { velocities, ablation rates }\end{array}$ \\
\hline 1993 & $\begin{array}{l}\text { Lundstrom et } \\
\text { al. }\end{array}$ & $\begin{array}{l}\text { Photogrammetric analysis of } 1984- \\
1989 \text { surface altitude change of the } \\
\text { partially debris-covered Eliot } \\
\text { Glacier, Mt. Hood, Oregon, U.S.A. }\end{array}$ & Topographic changes \\
\hline 2006 & $\begin{array}{l}\text { Lillquist \& } \\
\text { Walker }\end{array}$ & $\begin{array}{l}\text { Historical Glacier and Climate } \\
\text { Fluctuations at Mount Hood, Oregon }\end{array}$ & $\begin{array}{c}\text { Terminus fluctuations and } \\
\text { climate }\end{array}$ \\
\hline
\end{tabular}

Since Handewith's study, all research conducted by the Mazamas (Dodge, $1964 ; 1971 ; 1987)$ and Lundstrom $(1992 ; 1993)$ focused on morphological characteristics and ignored terminus fluctuations. Two transverse elevation profiles were established in 1940 (Figure 7) to measure thinning rates (Matthes and Phillips, 
1943; Handewith, 1959; Dodge, 1964) illustrating a thinning of the glacier at the upper profile (B) until the 1960s. Surface velocities at the B-profile dropped until 1959, when they increased from $1.4 \mathrm{~m} \mathrm{a}^{-1}$ to $6.9 \mathrm{~m} \mathrm{a}^{-1}$ (Phillips, 1942; Matthes and Phillips, 1943; Mason, 1954; Dodge, 1964).

Lundstrom noted surface velocities at the B-profile of $\sim 6.9 \mathrm{~m} \mathrm{a}^{-1}$. Dreidger and Kennard (1986) made radar measurements of the depth of Eliot Glacier as part of a study on ice volume throughout the Cascades. However, their study focused predominantly on the clean ice region above the debris-covered terminus. Lundstrom (1992; 1993) examined the debris cover, noting that it increased in the down-glacier direction from $0 \mathrm{~m}$ to $\sim 1.7 \mathrm{~m}$ at the terminus. Ablation rates ranged from $0.1 \mathrm{~cm} \mathrm{dy}^{-1}$ under thick debris cover (over $60 \mathrm{~cm}$ ) to $7.7 \mathrm{~cm} \mathrm{dy}^{-1}$ on clean ice, and the glacier was thinning at the B-profile at a rate of $0.8 \mathrm{~m} \mathrm{a}^{-1}$ in the late $1980 \mathrm{~s}$. 


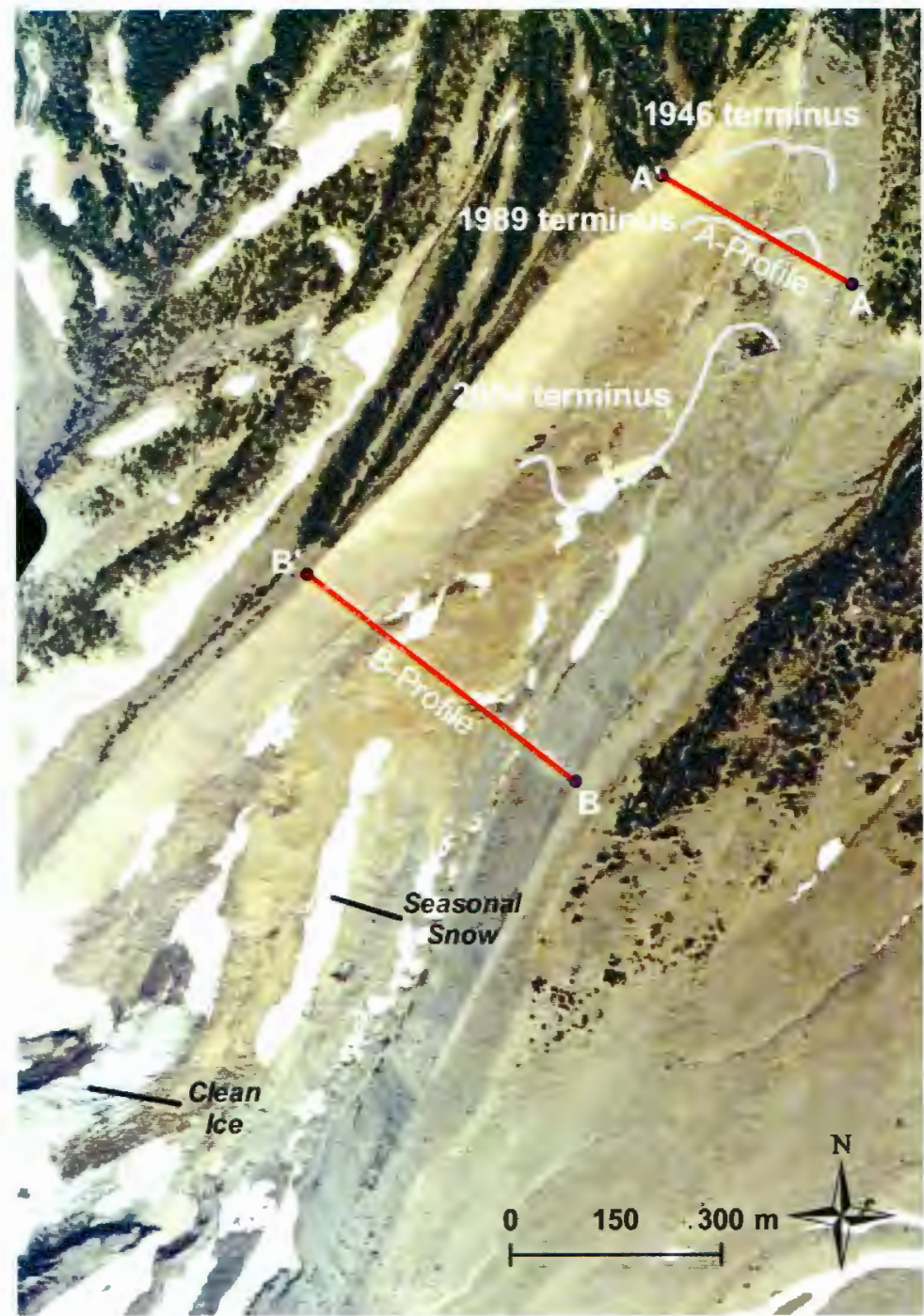

Figure 7. Locations of $\mathrm{A}$ and $\mathrm{B}$ profiles as well as selected terminus positions. Mazamas discontinued measuring the A-Profile after 1968. 


\section{GLACIER CHRONOLOGIES}

\section{Introduction}

Examining the spatial changes of Mount Hood and Collier Glacier provide a snapshot of glacier change in Oregon and offer a context for the changes of Eliot Glacier examined in the following chapters. I created a chronology of glacier extents on Mount Hood spanning 1901 through 2004. The glaciers examined include Eliot, Coe, Ladd, Sandy, Reid, White River, and Newton Clark. In addition, I include Collier Glacier (1910-1994), located on North Sister, $\sim 135 \mathrm{~km}$ south along the crest of the Oregon Cascades. The earliest source materials were black and white groundbased photographs (Reid, 1901) and the most recent were color aerial photographs acquired in 2004 (Table 2).

\section{Methods}

The majority of the glacial extents were created from aerial photographs acquired by the U.S. Forest Service, Mount Hood National Forest. The aerial photographs were georeferenced to the 2000 Mount Hood North and Mount Hood South digital orthophotograph quadrangles (DOQ). I georeferenced only the lower sections of the glaciers because the majority of the spatial change occurs near the terminus. This decreased the root mean square errors (RMSE) inherent with georeferencing in high relief areas such as the accumulation zone. Boulders and vegetation adjacent to the glaciers common to both photographs were fairly abundant and I used these as control points to adjust the scale of the unrectified photographs to 
that on the DOQ. I expect that boulder/vegetation movement is minimal on the crests compared to moraine slopes. I created a buffer around each perimeter (Nylen, 2004) to define the uncertainty associated with each glacier boundary. The magnitude of the buffer was based on the root mean square errors (RMSE) of the rectified aerial photographs (Appendix A). This should not affect the glacier delineations at the highest elevations (i.e., the accumulation zones) as the glaciers on Mount Hood are well-defined in incised basins.

Despite only rectifying the lower portions of the aerial photographs, entire glacier extents were delineated. I used unrectified aerial photographs of the summit area, which were not rectified because of high errors resulting from the large vertical relief, to delineate the upper reaches of the glaciers. I located common points on each and delineated the glacier extent on the DOQ from the unrectifed photograph. I used two adjacent computer monitors, one with the unregistered aerial photograph and the other with the 2000 DOQ for digitizing. This procedure was also implemented for the oblique photographs that could not be rectified. Terminus measurements were made to the point where a stream emits from the glacier, or, in the case of Eliot Glacier, halfway up the eastern arm of the terminus to account for its irregular shape. Newton Clark Glacier has a broad, wide terminus, excluding the possibility of accurate georeferencing because the amount of terrain required for a photograph was highly variable and RMSE values were too high. I estimate the areal extents to have a $15 \mathrm{~m}$ error for oblique aerial photographs and $20 \mathrm{~m}$ for ground photographs, based on visual observations of identifiable vegetation on lateral moraines and my digitizations. 
Table 2. Data sources for glacier chronologies on Mount Hood. COL-Color Aerial Photograph; B\&W-Black \& White Aerial Photograph; DOQ-Digital Orthophotograph Quadrangle; OBL-Oblique Aerial Photograph; TOPO-Topographic Map; GRDTerrestrial Ground Photograph; USFS-United States Forest Service; USGS-United States Geological Survey; OGS-Oregon Geospatial Data Clearinghouse.

\begin{tabular}{cccc} 
Data & Date & Scale/Resolution & Source \\
\hline COL & 23-Jul-04 & $1: 12,000$ & USFS \\
DOQ & 06-Aug-00 & $1 \mathrm{~m}$ & OGS \\
COL & 30-Jul-95 & $1: 12,000$ & USFS \\
COL & 03-Sep-89 & $1: 12,000$ & USFS \\
COL & 15-Aug-84 & $1: 12,000$ & USFS \\
COL & $15-J u l-79$ & $1: 12,000$ & USFS \\
COL & $10-$ Aug-72 & $1: 15,840$ & USFS \\
B\&W & $05-$ Sep-67 & $1: 15,840$ & USFS \\
B\&W & $16-$ Oct-59 & $1: 12,000$ & USFS \\
TOPO & 1956 & $1: 24,000$ & USGS \\
OBL & $02-$ Oct-56 & N/A & Mazamas \\
B\&W & $09-S e p-46$ & $1: 20,000$ & USFS \\
OBL & $25-S e p-35$ & N/A & Mazamas \\
TOPO & 1924 & $1: 125,000$ & USGS \\
TOPO & 1907 & $1: 125,000$ & USGS \\
GRD & 1901 & N/A & Mazamas \\
\hline
\end{tabular}

I also rephotographed a 1901 ground photograph taken by Harry Fielding Reid (Reid, 1901) and a 1935 ground photograph taken by A.J. Gilardi (Gilardi, 1935) to provide an intuitive, visual illustration of Eliot Glacier's spatial change. Identifying the exact locations for the rephotography proved difficult as vegetation has changed and even large boulders are missing since the original photographs were taken, thus none of them could be located precisely.

The historic maps and photographs for Collier Glacier cover the period 19101994 (Table 3). All but three glacier extents were created by Bob Pinotti (unpublished) from McDonald's (1995) thesis. I delineated the 1938, 1940-1942, and 1994 outlines. However, different investigators use different extents. On Collier Glacier, O'Connor et al. (2001) delineated ice fields to the west and south of the main 
trunk of Collier (1, 2 on Figure 8), whereas McDonald (1995) did not include these ice sections during the middle of the century, despite their presence through 1994. I delineated only the main trunk of Collier Glacier and ignored the tributaries to the west and south that did not seem to clearly contribute much ice flow to the glacier (Figure 8). Errors of McDonald (1995) are unknown.

Table 3. Data sources for Collier Glacier chronology. Key: B\&W-Black \& White Aerial Photograph; DOQ-Digital Orthophotograph Quadrangle; TOPO-Topographic Map; GRD-Terrestrial Ground Photograph; POLY-Polygon digitized in publication; USFS-United States Forest Service; USGS-United States Geological Survey; OGSOregon Geospatial Data Clearinghouse

\begin{tabular}{cccc} 
Data & Date & Scale/Resolution & Source \\
\hline DOQ & 1994 & $1 \mathrm{~m}$ & OGS \\
POLY & 1985 & N/A & Dreidger and \\
KEnnard, 1985 \\
B\&W & 09-Sep-82 & $1: 12,000$ & USFS \\
B\&W & $17-J u l-73$ & $1: 15,840$ & USFS \\
B\&W & $24-$ Aug-67 & $1: 12,000$ & USFS \\
TOPO & 1957 & $1: 24,000$ & USGS \\
GRD & 1949 & N/A & McDonald, 1995 \\
GRD & 1941 & N/A & McDonald, 1995 \\
GRD & 1938 & N/A & McDonald, 1995 \\
GRD & $1934-36$ & N/A & McDonald, 1995 \\
GRD & 1933 & N/A & McDonald, 1995 \\
GRD & 1910 & N/A & McDonald, 1995 \\
\hline
\end{tabular}




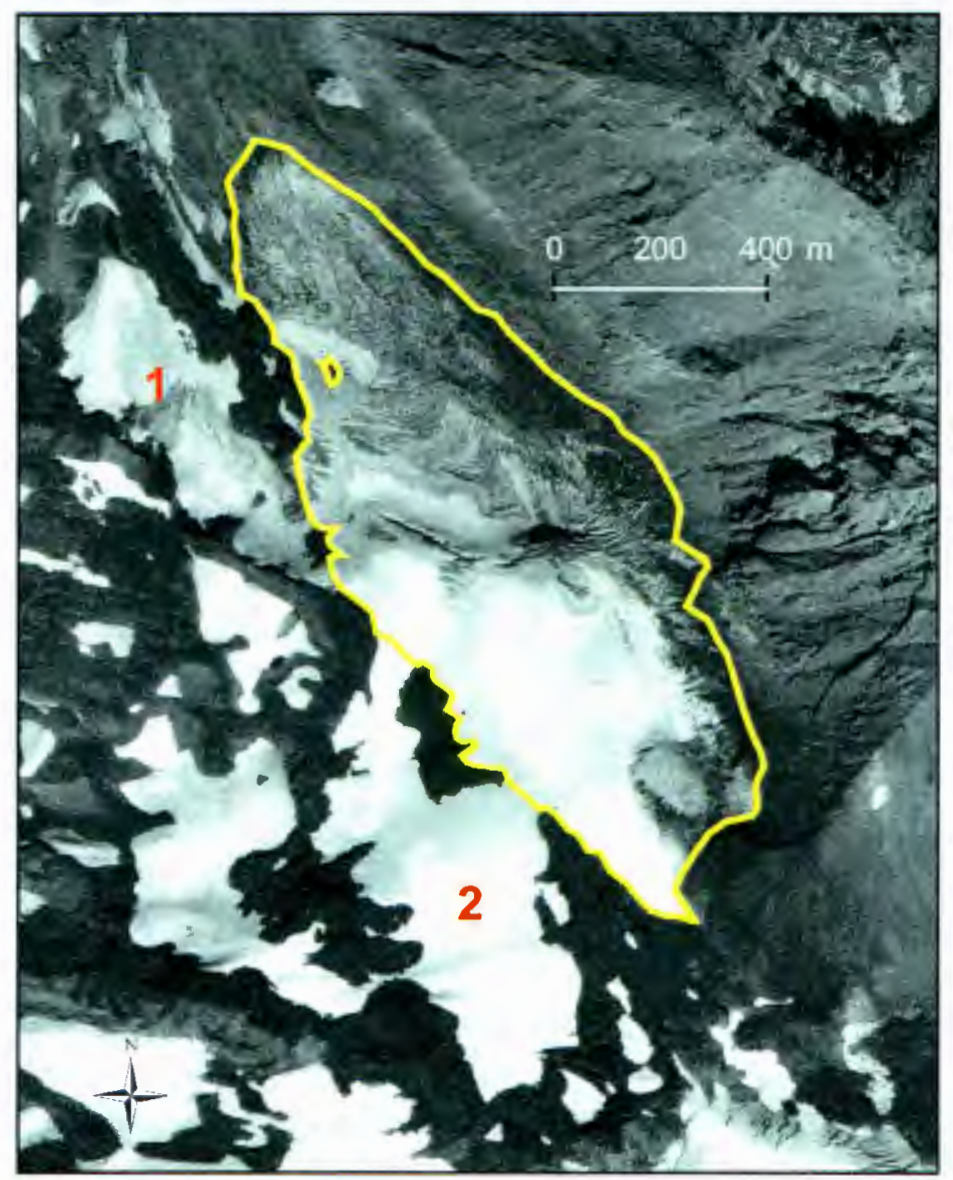

Figure 8. Collier Glacier, 1994. Glacier outline indicated in yellow, and two ice/snow bodies not included in analysis marked with (1) and (2). Base image is 1994 DOQ.

\section{Results}

On a whole, the seven Mount Hood glaciers lost approximately $34.3 \%$ of their glacier cover (Table 4). Glacier area decreased from $9.98 \pm 0.95 \mathrm{~km}^{2}$ in 1907 to 7.79 $\pm 0.33 \mathrm{~km}^{2}$ in 1946. By 1972 glacier area was close to 1946 at $7.77 \pm 0.42 \mathrm{~km}^{2}$, and decreased to $6.78 \pm 0.48 \mathrm{~km}^{2}$ in 2004 . The six glaciers examined retreated through the first half of the 1900s, advanced or at least slowed their retreat dramatically in the 1960s and 1970s, and retreated since then, although their magnitudes differed. Coe Glacier lost the least area (14.6\%), while White River Glacier lost the most (61\%) of 
its 1907 surface area. Eliot Glacier decreased in area from $2.03 \pm 0.16 \mathrm{~km}^{2}$ in 1901 to $1.64 \pm 0.05 \mathrm{~km}^{2}$ in 2004 , a loss of $19.3 \%$ of its 1901 area (Figure 9) and the terminus retreated about $600 \mathrm{~m}$. (Figure 10a). The Mazamas measured the 1901-1936 retreat to be about $360 \mathrm{ft}(\sim 110 \mathrm{~m})$ (Phillips, 1938), whereas reconstructions show a retreat of $120 \pm 25 \mathrm{~m}$. Eliot retreated to $1.81 \pm 0.13 \mathrm{~km}^{2}$ by 1956 and then began to advance until the early 1970 s when it began to retreat again. The most pronounced retreat of the past 103 years has occurred since 1995 with Eliot losing $0.14 \pm 0.05 \mathrm{~km}^{2}$ from 1995 to 2004.

Collier Glacier has experienced a somewhat different trend compared to the glaciers of Mount Hood. In 1910, Collier Glacier was $1.81 \mathrm{~km}^{2}$ and then retreated dramatically to $0.87 \mathrm{~km}^{2}$ by 1941 , a loss of $51.9 \%$ (Figure 9 ). It advanced slightly in 1949 and then retreated once again by 1974 . In 1994 Collier Glacier was $0.65 \mathrm{~km}^{2}$, a cumulative loss of $63.9 \%$ and a retreat of almost $1500 \mathrm{~m}$ since 1910 (Figure 10b). The DOQ of Collier Glacier in 2000 contains too much late season snowpack to discern the glacier outline. 
Table 4. Areas and terminus retreats for seven Mount Hood glaciers in this thesis and Collier Glacier, North Sister, Oregon. Collier Glacier values are 1910 and 1994 rather than 1907 and 2004. Eliot Glacier value is 1901 rather than 1907

\begin{tabular}{|c|c|c|c|c|c|}
\hline Glacier & $\begin{array}{c}1907 \text { Area } \\
\left(\mathrm{km}^{2}\right)\end{array}$ & $\begin{array}{c}2004 \text { Area } \\
\left(\mathrm{km}^{2}\right)\end{array}$ & Loss $\left(\mathrm{km}^{2}\right)$ & Loss (\%) & $\begin{array}{c}\text { Terminus } \\
\text { Retreat (m) } \\
\end{array}$ \\
\hline Coe & $1.41 \pm 0.13$ & $1.2 \pm 0.02$ & 0.21 & 15 & 390 \\
\hline Collier & 1.81 & 0.65 & 1.16 & 64 & 1520 \\
\hline Eliot & $2.03 \pm 0.16$ & $1.64 \pm 0.05$ & 0.39 & 19 & 680 \\
\hline Ladd & $1.07 \pm 0.10$ & $0.67 \pm 0.05$ & 0.40 & 37 & 1190 \\
\hline Newton Clark & $2.06 \pm 0.15$ & $1.40 \pm 0.14$ & 0.66 & 32 & 310 \\
\hline Reid & $0.79 \pm 0.13$ & $0.51 \pm 0.05$ & 0.28 & 36 & 490 \\
\hline Sandy & $1.61 \pm 0.17$ & $0.96 \pm 0.14$ & 0.65 & 40 & 690 \\
\hline White River & $1.04 \pm 0.11$ & $0.41 \pm 0.03$ & 0.63 & 61 & 510 \\
\hline Total & $11.82 \pm 0.95$ & $7.44 \pm 0.48$ & 4.38 & - & 5780 \\
\hline Average & $1.48 \pm 0.14$ & $0.93 \pm 0.07$ & 0.55 & 38 & 723 \\
\hline
\end{tabular}



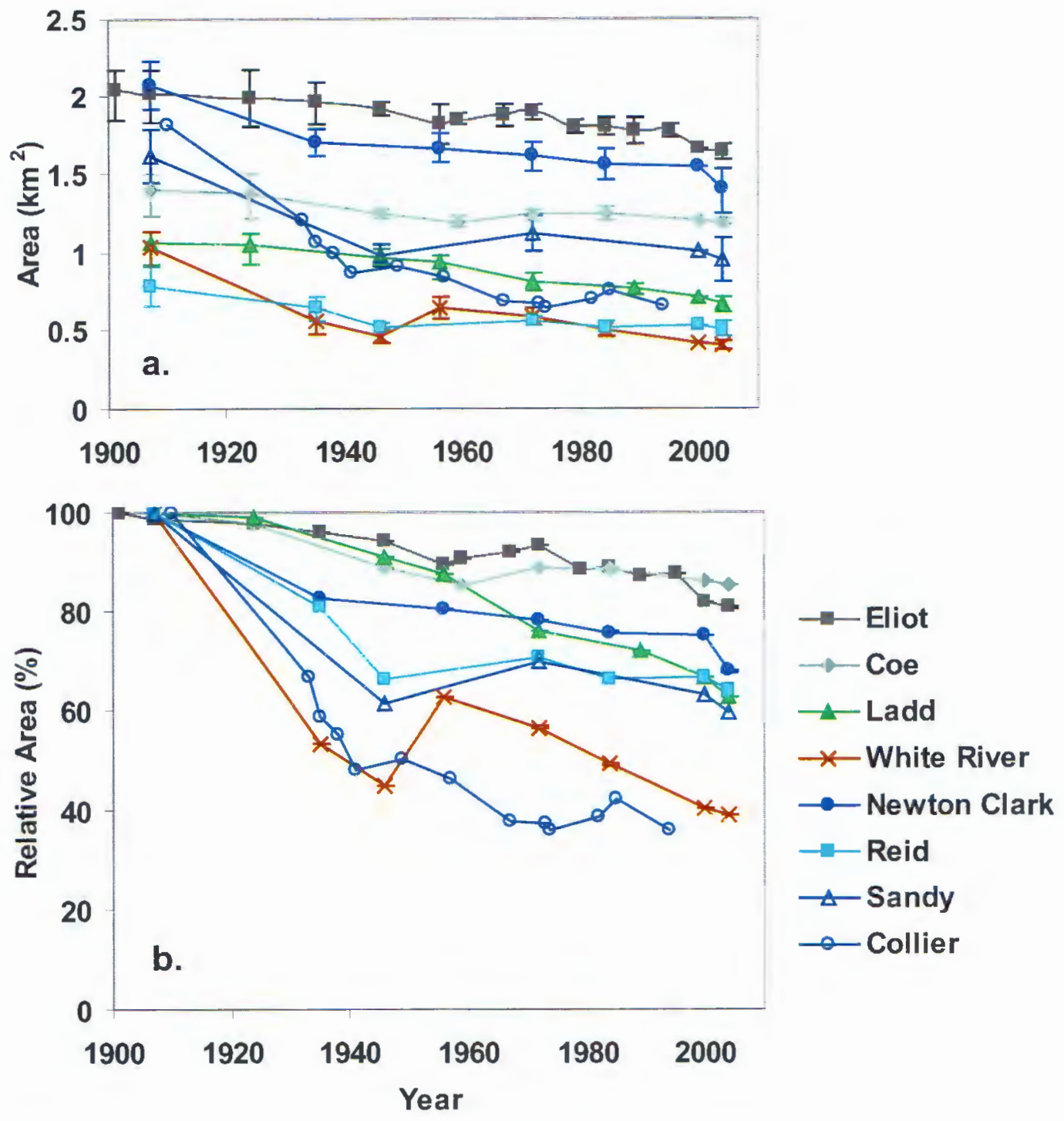

Figure 9. Glacier area over time on Mt. Hood and Collier Glacier (a) and same values normalized (b). Note: Collier Glacier errors are unknown (McDonald, 1995). 

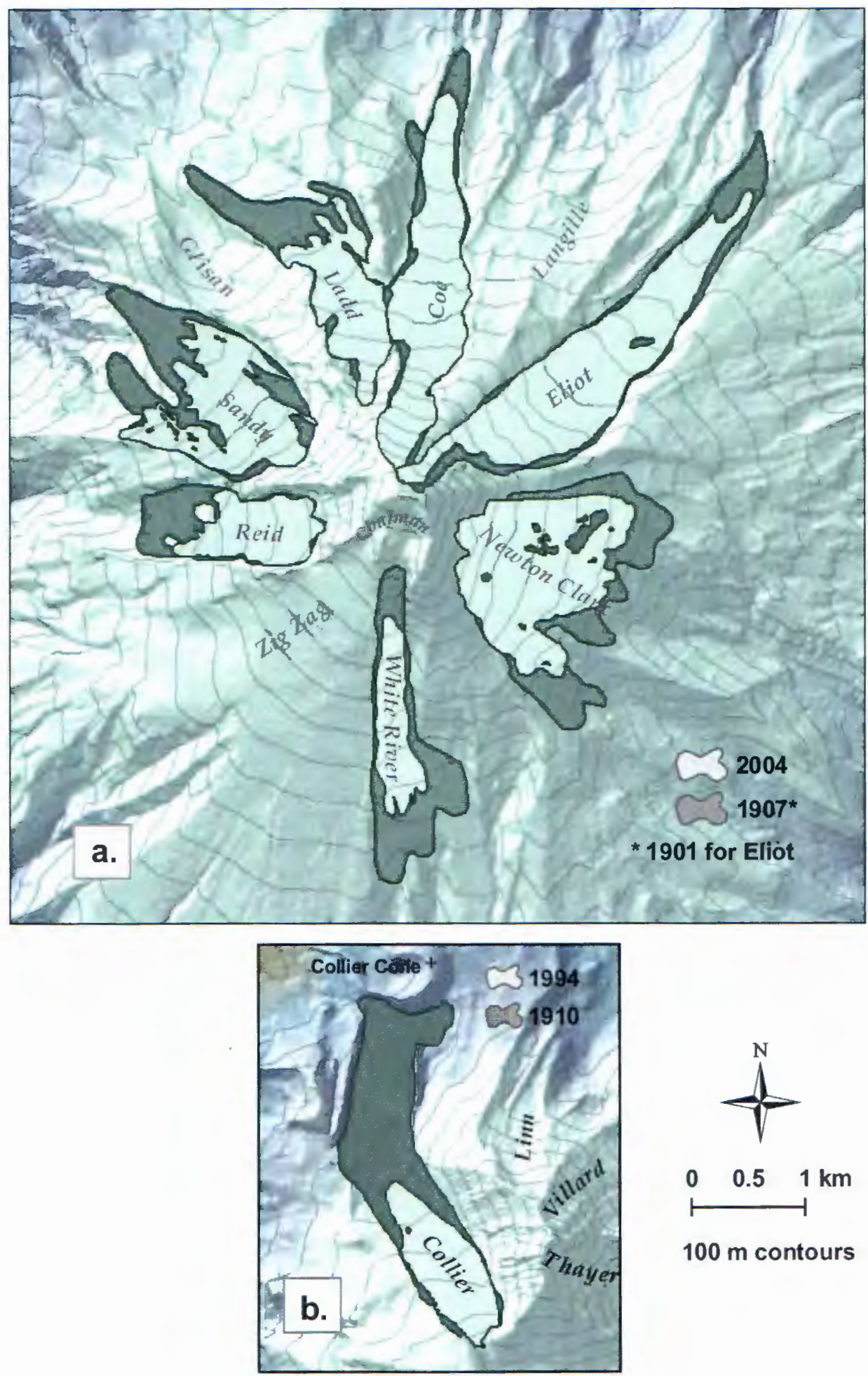

$100 \mathrm{~m}$ contours

Figure 10. Map of glacier change since early 20th century on (a) Mt. Hood and (b) retreat of Collier Glacier over similar timespan. 
A July 23, 1901 photograph was taken on the western lateral moraine and displays the "clean" area of the glacier. I rephotographed the scene on July 22, 2005 and the most obvious difference is the late-season snow, much less in 2005 . However, closer inspection reveals significant glacial thinning has occurred (Figure 11). From these photographs I estimate, very roughly, the thinning on the identified areas is 50 m. Additionally, flow directions at area (c) appear to have changed as ice flow is now limited to a down-glacier direction between the two constricting bedrock features.
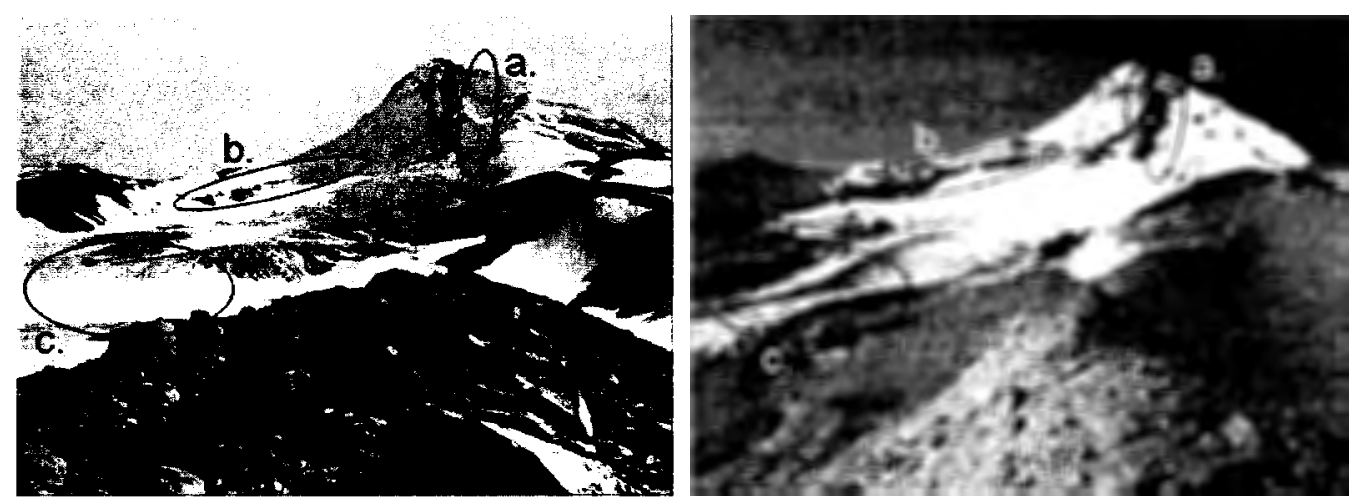

Figure 11. July 23, 1901 photograph (taken by Reid) on left (Mazamas reference \# p17), July 22, 2005 photograph on right. The area to the west of the headwall (a), the large cliff-face of Cooper Spur (b), and two large bedrock humps have been exposed just down-glacier of the current ELA (c).

Another pair of photographs, September 15, 1935 and July 22, 2005, shows extensive retreat and thinning (Figure 12). The large cliff-face of Cooper Spur, as seen in the 1901 repeat photograph, has become exposed, as well as the area west of the headwall, but more importantly the terminus has retreated and thinned from almost the height of the lateral moraines to its current location. 

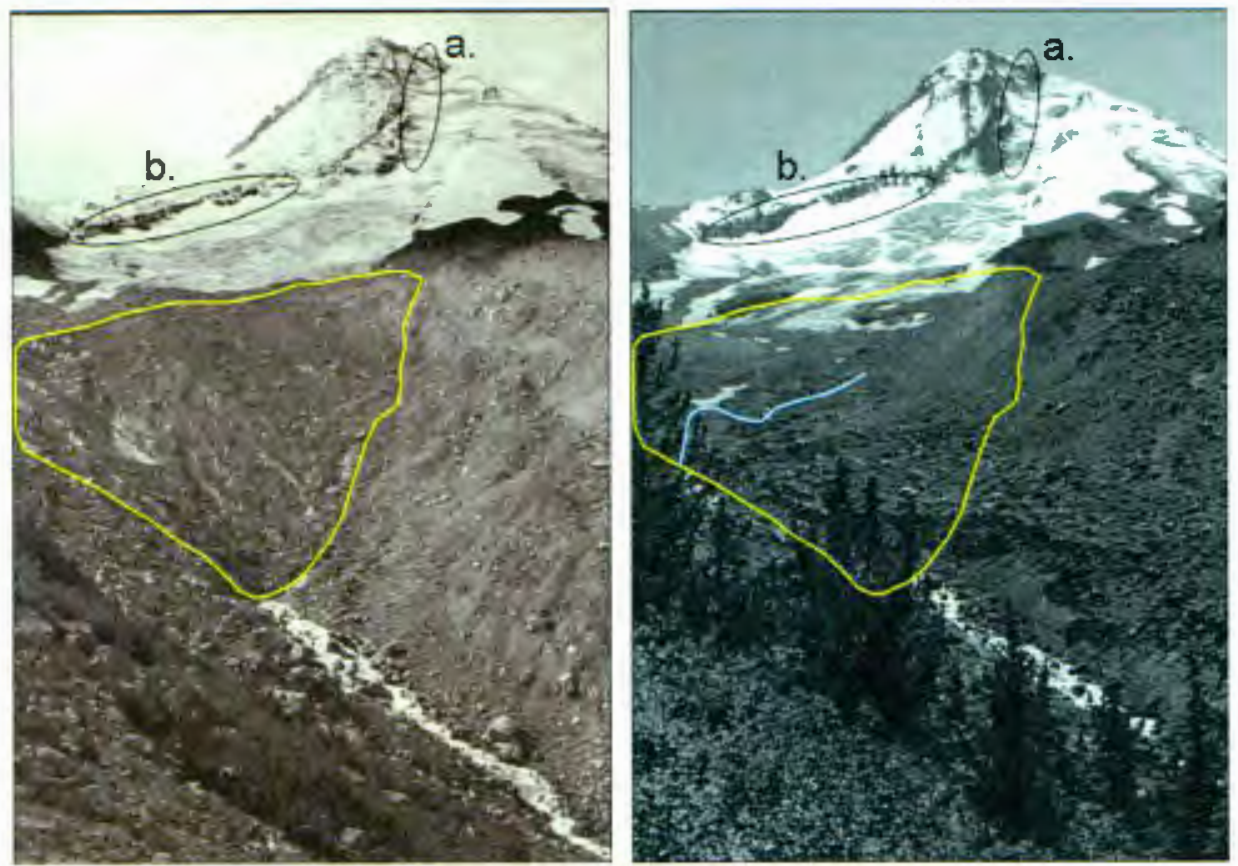

Figure 12. September 15, 1935 photograph (Gilardi) on left (Mazamas reference \# p16), July 22, 2005 photograph on right. Terminus position traced on 1935 photo and superimposed on 2005 image to illustrate magnitude of thinning and retreat since 1935. Current terminus labeled in light blue on right image.

\section{Analysis}

Aspect appears to play a large role in determining the magnitude of glacier retreat on Mount Hood. Glaciers with NW, N, or NE aspects lost an average of 28\% of their areas while glaciers from southerly aspects (including $\mathrm{E}$ and $\mathrm{W}$ ) lost an average of $43 \%$ (Table 5). Similar results have been seen on Mount Rainier where south-facing glaciers lost $26.5 \%$ of their area between 1913 and 1994 whereas northfacing glaciers lost 17.5\% (Nylen, 2004). Additionally, in the Austrian Alps, southfacing glaciers lost 36\% of their area between 1973 and 1992 while north aspect glaciers only lost 5.8\% (Paul, 2002). Aspect, however, is just an indirect cause of the difference in spatial glacier retreat patterns. In a constant climate scenario, south- 
facing glaciers would be smaller than north-facing glaciers resulting from more solar radiation. Smaller glaciers display areal change quicker and in higher magnitude than large glaciers, as demonstrated by Granshaw and Fountain (2006), Paul (2002), and Nylen (2004), and as such south-facing glaciers will retreat more than larger glaciers. Other Oregon Cascade stratovolcanoes such as Mount Thielsen (Lafrenz, 2001) and Three Fingered Jack (O'Connor et al., 2001) have small remaining glaciers that are confined to north or northeast aspects, which have persisted because of originally larger sizes than their south-facing counterparts as well as headwall shading.

Table 5. Mount Hood's glaciers and the effect of aspect on glacier retreat

\begin{tabular}{ccccc} 
Glacier & Aspect (ang.) & Aspect (dir.) & Loss $\mathbf{( k m}^{\mathbf{2}}$ ) & Loss (\%) \\
\hline Coe & 11 & N & 0.21 & 15 \\
Eliot & 42 & NE & 0.39 & 19 \\
Ladd & 349 & N & 0.40 & 37 \\
Newton Clark & 109 & E & 0.66 & 32 \\
Reid & 278 & W & 0.28 & 36 \\
Sandy & 314 & NW & 0.65 & 40 \\
White River & 152 & SE & 0.63 & 61 \\
\hline Average & - & - & $\mathbf{0 . 4 6}$ & $\mathbf{3 4}$ \\
\hline
\end{tabular}




\section{ABLATION AND DEBRIS THICKNESS}

\section{Introduction}

The spatial and temporal variation in ablation and debris thickness across the glacier is important for understanding the history of the glacier's mass balance processes and indirectly glacier dynamics. Debris cover exceeding a threshold value of $2 \mathrm{~cm}$ (Lundstrom, 1992) insulates the ice and inhibits melt, and for thicknesses less than $2 \mathrm{~cm}$, melt is accelerated. I measured ice ablation and debris thicknesses over the debris-covered area of the glacier and compared the ablation values to previous measurements (Matthes and Phillips, 1943; Mason, 1954; Dodge, 1964; 1971; 1987).

\section{Methods}

Fourteen PVC stakes were drilled into the ice to measure surface velocity and ice ablation. Only one location was free of debris. At the other 13 locations, I measured the debris thickness by digging down to the ice surface and measuring the depth. Each hole in the ice was drilled to between 2.0 and $3.5 \mathrm{~m}$ deep and two PVC pipes (each $\sim 1.8 \mathrm{~m}$ long) attached to each other with a zip tie were inserted in the hole, creating a stake. The debris was then replaced around the stake. Ablation was estimated from the changing distance (lengthening) measured from the top of the stake to a board around the stake on the debris or ice surface. The board provided an even surface averaging out the roughness of the debris cover (Figure 13). I made two measurements on opposite sides of the stake and averaged them. Depending on other tasks and weather, some stakes were measured on a near-daily basis while others were measured about once a week between August $13^{\text {th }}$ and September $24^{\text {th }}, 2004$. All 
stakes were measured the following season on July $28^{\text {th }}, 2005$ during a velocity survey yielding a total interval of 350 days. In addition to the debris thickness data collected at the stakes, I measured debris thicknesses at 17 additional locations. These additional locations were chosen to fill in gaps in a map of debris thicknesses that Granshaw and others made in 2001.

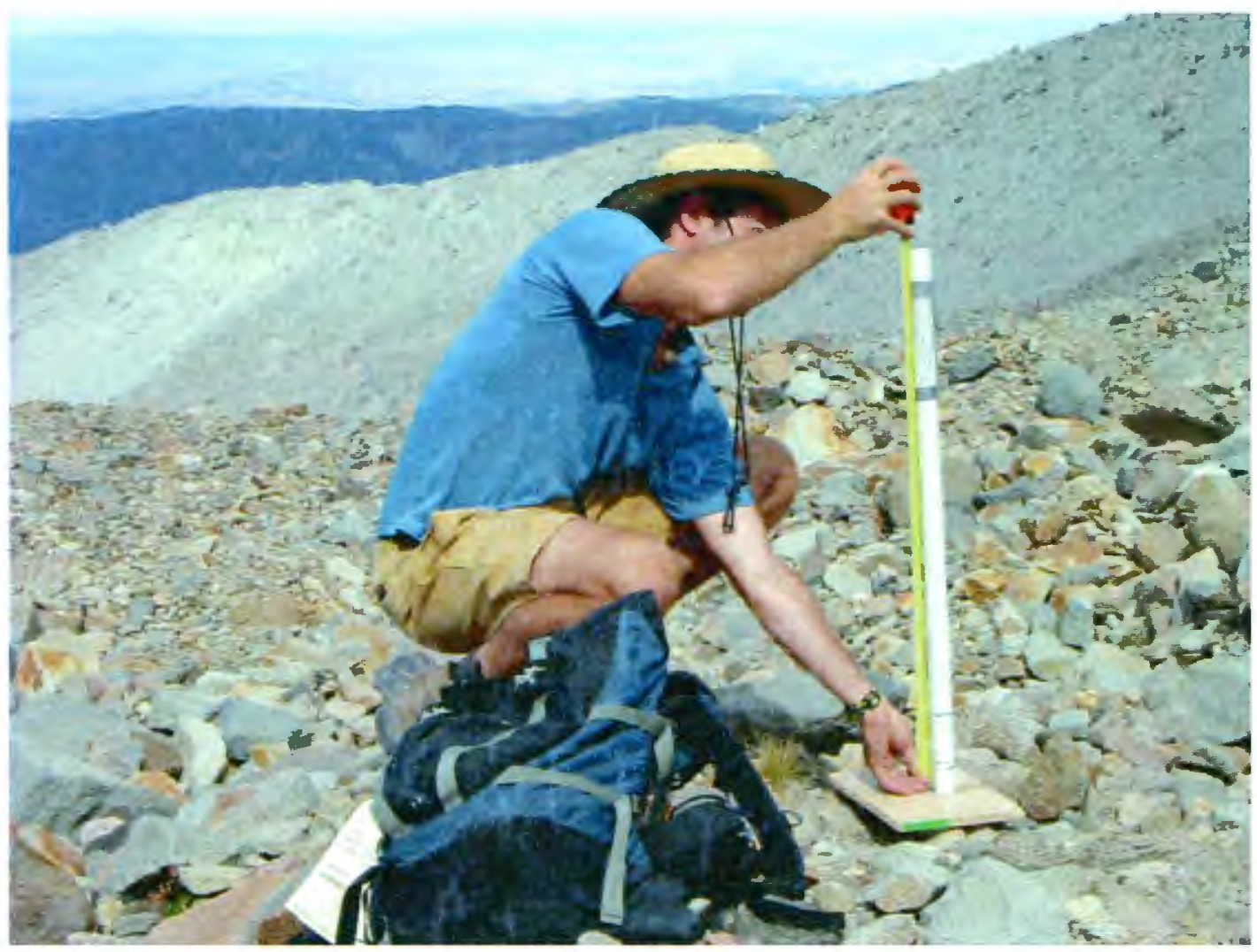

Figure 13. Measuring a stake for ablation (timer photo by author)

\section{Results}

In general, the debris cover thickens down-glacier from the uppermost stake, 12, and towards the sides of the glacier (Figure 14, Figure 15). Debris is thicker on the eastern side of the glacier which reflects the input of Cooper Spur (Figure 6) as compared to the small input from the western side. Thicker debris cover on the lateral 
margins is representative of mass wasting from the large lateral moraines. The englacial transport of debris through the glacier from the headwall results in higher debris concentrations near the terminus of the glacier than at higher elevations (Lundstrom, 1992).

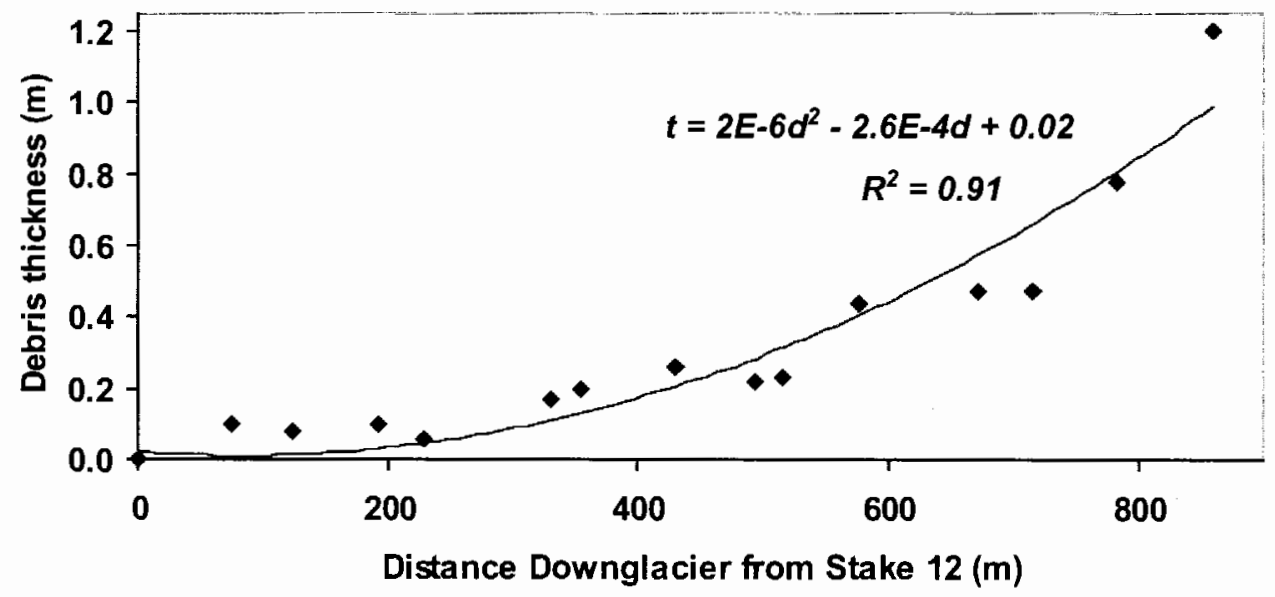

Figure 14. Longitudinal profile of debris thickness (terminus is approximately the farthest downglacier point). The trendline is a 2 nd order polynomial. $t=$ Debris thickness, $d=$ Distance downglacier. 


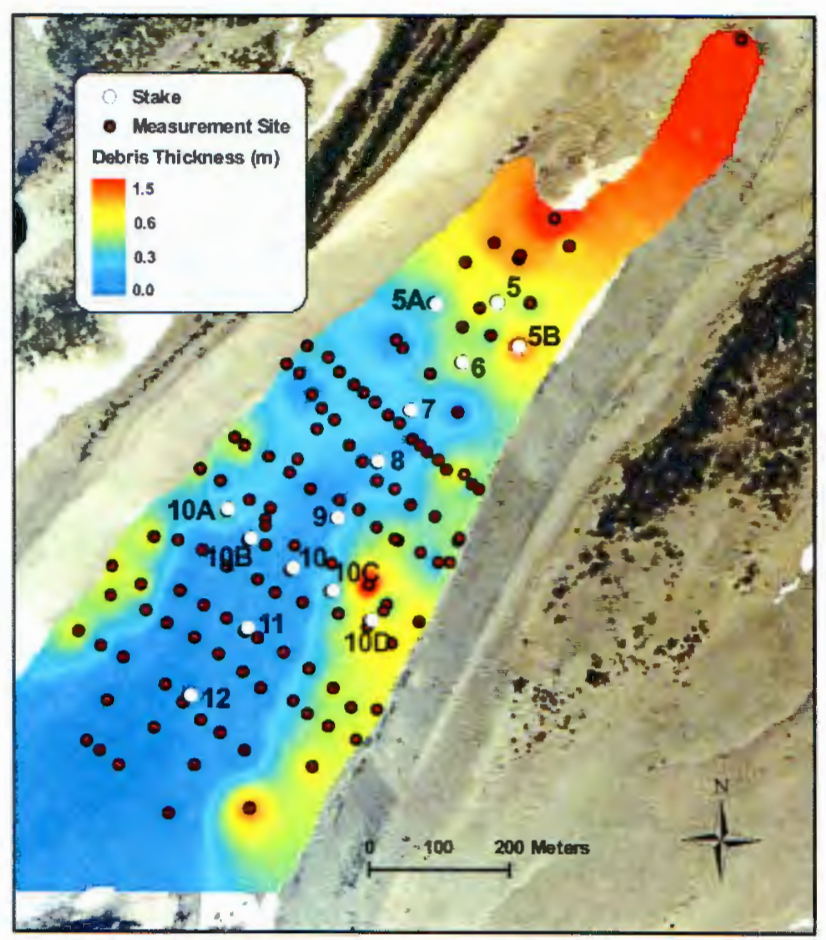

Figure 15. Debris thicknesses of Eliot Glacier. The measurement sites are a combination of my measurements and those of Granshaw and others in 2001. Map was created in ArcGIS/Spatial Analyst software using an inverse distance weighting scheme.

Ablation values range from nearly $3.81 \mathrm{~m} \mathrm{a}^{-1}$ to $0.31 \mathrm{~m} \mathrm{a}^{-1}$ (Table 6). Annual values are extrapolated from measurements over a 350-day period. Stake 12, located on clean ice when drilled, ablated $365 \mathrm{~cm}$ over the 350 -day period averaging $1.0 \mathrm{~cm}$ $\mathrm{dy}^{-1}$, and ablated $175 \mathrm{~cm}$ over the 6-week summer study period August 13-September 24,2004 (an average of $4.2 \mathrm{~cm} \mathrm{dy}^{-1}$ ) with peaks as high as $10 \mathrm{~cm} \mathrm{dy}^{-1}$. When surveyed for movement on July $28,2005, \sim 1 \mathrm{~cm}$ of debris covered the ice at the stake because it moved into the beginning of the debris-covered zone (about $7.5 \mathrm{~m}$ down-glacier from its original position). Summer ablation is responsible for between $31-59 \%$ of annual ablation (average $=41 \%$ ) (Figure 16). Ablation decreases with thicker debris cover (Figure 17) and with distance down-glacier as debris cover thickens (Figure 18). 
debris cover (Figure 17) and with distance down-glacier as debris cover thickens (Figure 18).

Table 6. Annual and summer (6-week period = Aug 13 - Sept 24, 2004) ablation values with corresponding debris thicknesses. Annual values are extrapolated from measurements over a 350-day period. A washout occurred around stake 6 during a rainstorm and reduced the debris cover from 51.5 to $40 \mathrm{~cm}$ between August 21 - 24, 2004.

\begin{tabular}{|c|c|c|c|c|c|c|}
\hline \multirow[b]{2}{*}{ STAKE } & \multirow{2}{*}{$\begin{array}{l}\text { Debris } \\
\text { thickness } \\
\text { (cm) }\end{array}$} & \multicolumn{2}{|c|}{ ANNUAL } & \multicolumn{2}{|c|}{6 WEEK SUMMER } & \multirow{2}{*}{$\begin{array}{l}\text { SUMMER PEAK } \\
\text { Avg Rate }\left(\mathrm{cm} \mathrm{dy}^{-1}\right)\end{array}$} \\
\hline & & $\begin{array}{l}\text { Total } \\
(\mathrm{cm})\end{array}$ & $\begin{array}{l}\text { Avg Rate } \\
\left(\mathrm{cm} \mathrm{dy}^{-1}\right)\end{array}$ & $\begin{array}{l}\text { Total } \\
(\mathrm{cm})\end{array}$ & $\begin{array}{l}\text { Avg Rate } \\
\left(\mathrm{cm} \mathrm{dy}^{-1}\right)\end{array}$ & \\
\hline 12 & 0 & 381 & 1.04 & 175 & 4.17 & 10 \\
\hline 11 & 6 & 347 & 0.95 & 108 & 2.57 & 3 \\
\hline 10 & 8 & 230 & 0.63 & 111 & 2.63 & 5 \\
\hline $10 \mathrm{~A}$ & 43 & 88 & 0.24 & 25 & 0.59 & 1 \\
\hline $10 \mathrm{~B}$ & 11 & 148 & 0.41 & 49 & 1.16 & 2 \\
\hline $10 \mathrm{C}$ & 27 & 102 & 0.28 & 33 & 0.78 & 2 \\
\hline $10 \mathrm{D}$ & 70 & 31 & 0.08 & 14 & 0.33 & 1 \\
\hline 9 & 17 & 146 & 0.40 & 47. & 1.11 & 2 \\
\hline 8 & 26 & 108 & 0.30 & 37 & 0.87 & 3 \\
\hline 7 & 23 & 132 & 0.36 & 42 & 1.00 & 2 \\
\hline 6 & 40 & 114 & 0.31 & 84 & 2.27 & 3 \\
\hline 5 & 47 & 47 & 0.13 & 23 & 0.55 & 1 \\
\hline $5 \mathrm{~A}$ & 32 & 112 & 0.31 & 37 & 0.88 & 2 \\
\hline $5 \mathrm{~B}$ & 90 & 45 & 0.12 & 27 & 0.63 & 3 \\
\hline
\end{tabular}




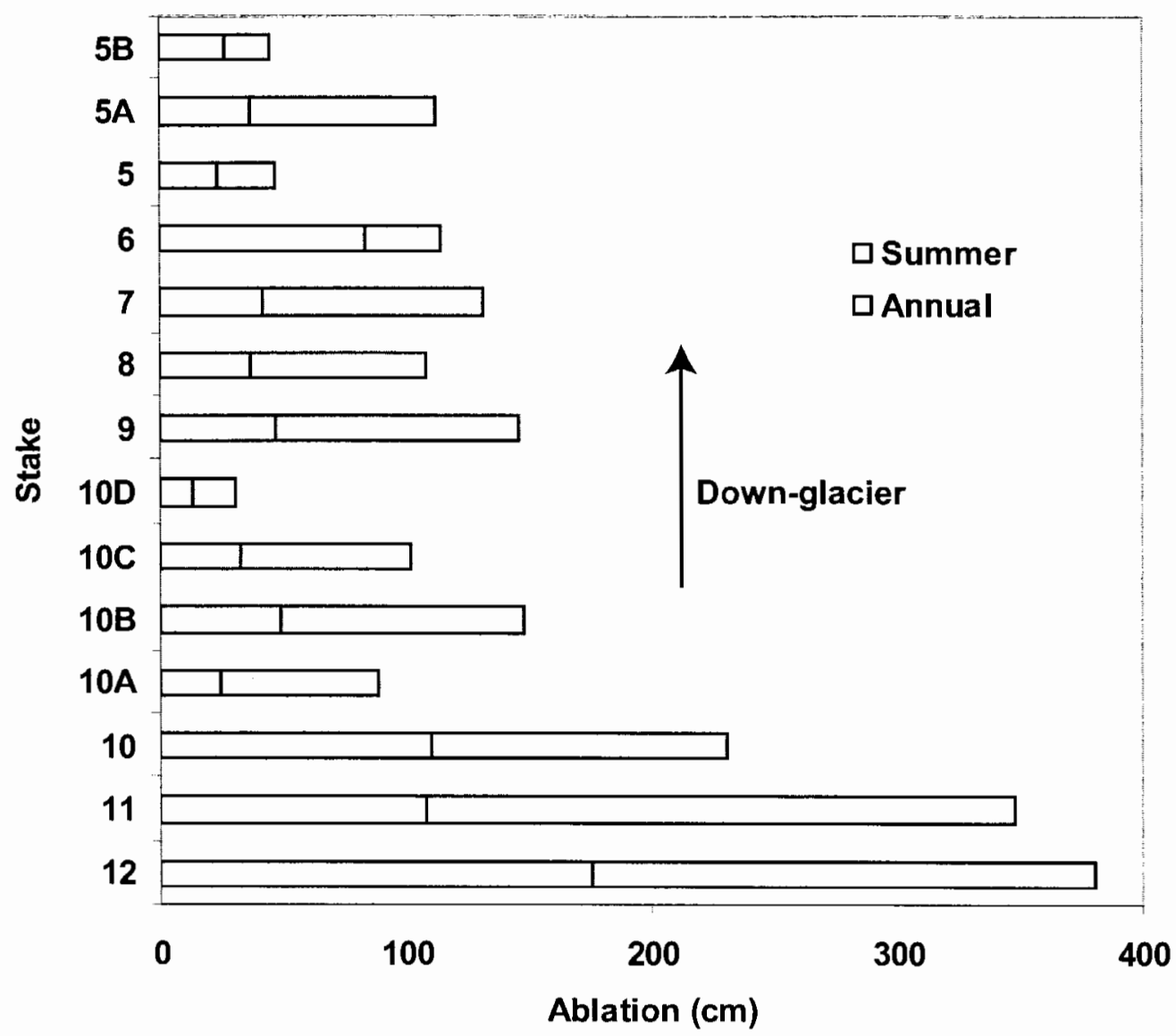

Figure 16. Summer and annual ablation levels-summer ablation accounts for an average of $41 \%$ of annual ablation. The six-week summer study period was August 13 - September 24, 2004. 


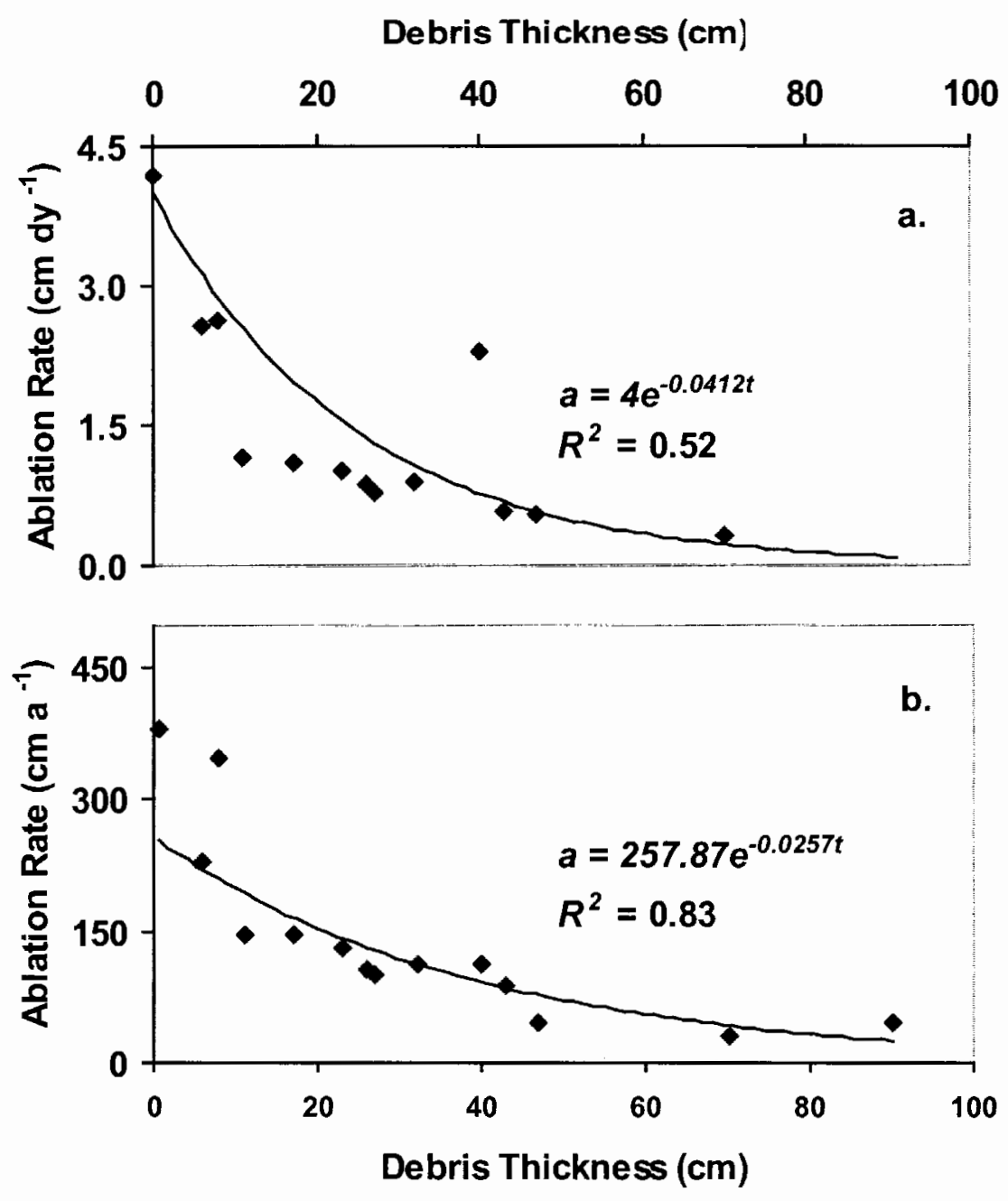

Figure 17. (a) Summer ablation rates with increasing debris thickness. The major outlier in the center is stake 6, where the washout occurred. (b) Annual ablation rates and increasing debris thickness. The trendlines are exponential lines, $\mathrm{a}=\mathrm{ab}$ abtion, $\mathrm{t}=$ debris thickness. 


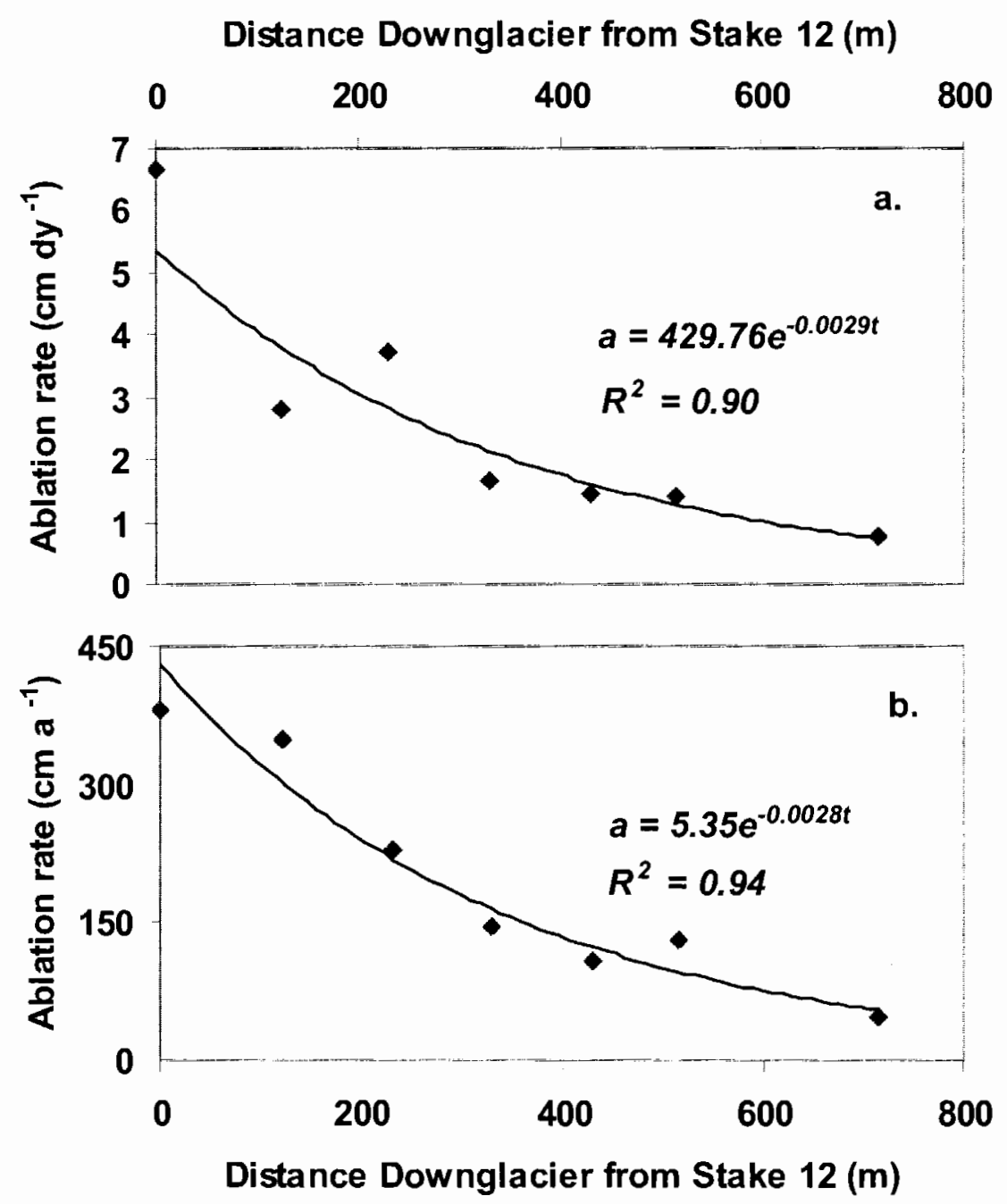

Figure 18. (a) Summer ablation rates and distance downglacier, (b) annual ablation rates and distance downglacier from stake 12 . The trendlines are exponential lines, $\mathrm{a}=$ ablation, $\mathrm{t}=$ debris thickness.

\section{Analysis}

Ice ablation is controlled by debris thickness and the energy balance between the debris-air interface. I compare ablation to debris thickness and air temperature, a proxy for the energy balance, to understand the change in ablation with distance 
down-glacier. Local air temperature was measured by Robert Schlichting at a meteorological station on the glacier during the summer of 2004 which recorded values on 20-minute intervals. The station was located close to stake 7 at an elevation of $2000 \mathrm{~m}$ and two temperature probes were used, one at $1 \mathrm{~m}$ above the debris surface and the other at $3 \mathrm{~m}$. The $1 \mathrm{~m}$ high probe had malfunctions between August $24^{\text {th }}$ and $29^{\text {th }}, 2004$, while the $3 \mathrm{~m}$ high probe malfunctioned on August $29^{\text {th }}$. As such, I used the $3 \mathrm{~m}$ probe until August $29^{\mathrm{th}}$, at which point I switched to the $1 \mathrm{~m}$ high probe data. I applied a dry adiabatic lapse rate of $0.98^{\circ} \mathrm{C} / 100 \mathrm{~m}$ to calculate temperatures at stake 12. This is likely an overestimate of the actual lapse rate because the air was not always in a dry state over the six week study period, but for my purposes is suitable because a consistent lapse rate on the glacier surface is the only necessary criteria for this analyis. I created two separate plots for each stake—one compares daily ablation and degree days and the other compares cumulative ablation with cumulative degree days. Degree days are a measure of the maximum temperature above $0^{\circ} \mathrm{C}$ on a given day. For example, if the temperature reaches $10^{\circ} \mathrm{C}$, that is 10 degree days. Both stakes 12 and 7 show linear relationships between ablation and degree days (Figure 19). The magnitude of ablation is approximately four times as large for stake 12 as stake 7, though. Stake 12's cumulative ablation ranges from 0 to over $170 \mathrm{~cm}$ as compared to stake 7's cumulative ablation range of 0 to $42 \mathrm{~cm}$. Stakes 7 and 12 have very similar degree day values yet different ablation values which demonstrate the effect of the debris layer on ablation rates. 

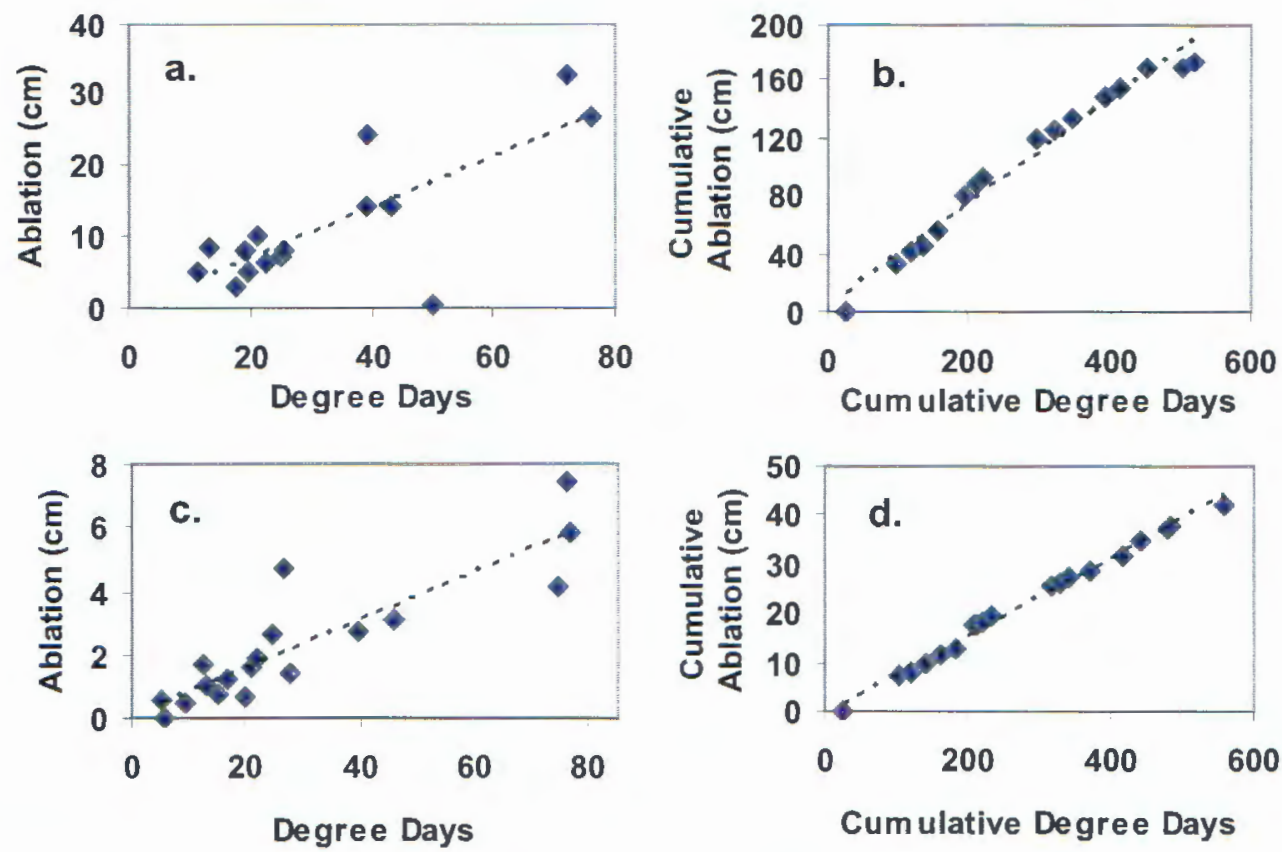

Figure 19. (a) Stake 12, ablation as a function of degree days, (b) Stake 12, cumulative ablation as a function of cumulative degree days; (c) Stake 7, ablation as a function of degree days, (d) Stake 7, cumulative ablation as a function of cumulative degree days.

A multiple linear regression analysis (with an a priori significance p-value $<$ $0.1)$ shows that debris cover has a significant effect on ablation (melt) while temperature does not (Table 7). Separately, the linear regressions between ablation and temperature or ablation and debris thickness, the p-value is lowest for ablation and debris thickness. These results are demonstrative of the larger effect of debris cover than temperature on ablation rates of lower Eliot Glacier. This is consistent with the insulation provided by a large range of debris thicknesses $(0$ to $90 \mathrm{~cm})$ compared to the small range of average summer temperatures $\left(12.0\right.$ to $\left.13.4^{\circ} \mathrm{C}\right)$ over a limited elevational range $(\sim 200 \mathrm{~m})$. 
Table 7. Ablation as a function of temperature and debris regression results. $\mathrm{A}=$ ablation, $\mathrm{T}=$ temperature, $\mathrm{D}=$ debris thickness.

\begin{tabular}{|c|c|c|c|c|c|c|}
\hline \multicolumn{3}{|c|}{$\mathbf{A}=\alpha \mathbf{T}+\boldsymbol{\beta D}+\boldsymbol{\gamma}$} & \multicolumn{2}{|c|}{ Ablation $=\alpha \mathbf{\alpha}+\beta$} & \multicolumn{2}{|c|}{ Ablation $=\alpha \mathrm{D}+\beta$} \\
\hline$R^{2}$ & $\mathrm{p}$-value $(\mathrm{T})$ & p-value (D) & $R^{2}$ & p-value & $R^{2}$ & p-value \\
\hline 0.43 & 0.47 & 0.07 & 0.23 & 0.09 & 0.40 & 0.01 \\
\hline \multicolumn{3}{|c|}{$\mathrm{A}=-20.26 \mathrm{~T}-0.97 \mathrm{D}+346.65$} & \multicolumn{2}{|c|}{$A=-49.12 T+682.76$} & \multicolumn{2}{|c|}{$A=-1.16 \mathrm{~T}+95.08$} \\
\hline
\end{tabular}

Annual ablation rates appear to have changed at the B-Profile since measurement began in 1940. Rates in the early-1940s were about $1.95 \mathrm{~m} \mathrm{a}^{-1}$ (Matthes and Phillips, 1943), dropping to about $1.08 \mathrm{~m} \mathrm{a}^{-1}$ between 1940 and 1956 (Mason, 1954; Handewith, 1959), and current ablation rate is about $1.23 \mathrm{~m} \mathrm{a}^{-1}$. Lundstrom's (1992) debris thickness results, measured in the late 1980s, appear very similar to mine indicating little or no change over the past 15-20 years. A quantitative comparison is not possible, though, as his data is on a local coordinate system that could not be converted to mine.

Comparing my summer ablation rates with Lundstrom's (1992) shows little to no difference (Figure 20). I hypothesize that the debris layer's insulating properties outweigh the effect of warmer temperatures, and a thickening of the debris layer is a likely cause of this. PRISM mean monthly temperatures for the period of Lundstrom's study and mine support this hypothesis. Mean summer (July-September) temperatures from PRISM (Daly et al., 1997) between 1987 and 1989 were $9.6{ }^{\circ} \mathrm{C}$ while mean summer temperatures for 2004 and 2005 were $11.5^{\circ} \mathrm{C}$.

Kayastha et al. (2000) examined ablation rates under varying debris thicknesses on Khumbu Glacier, Nepal. Their results are similar suggesting that different mountain ranges and possibly local ablation patterns are buffered by the 
effects of the debris cover (Figure 20). However, ablation rates on clean ice were higher at Eliot (this study and Lundstrom, 1992), but this may be a result of local temperature differences.

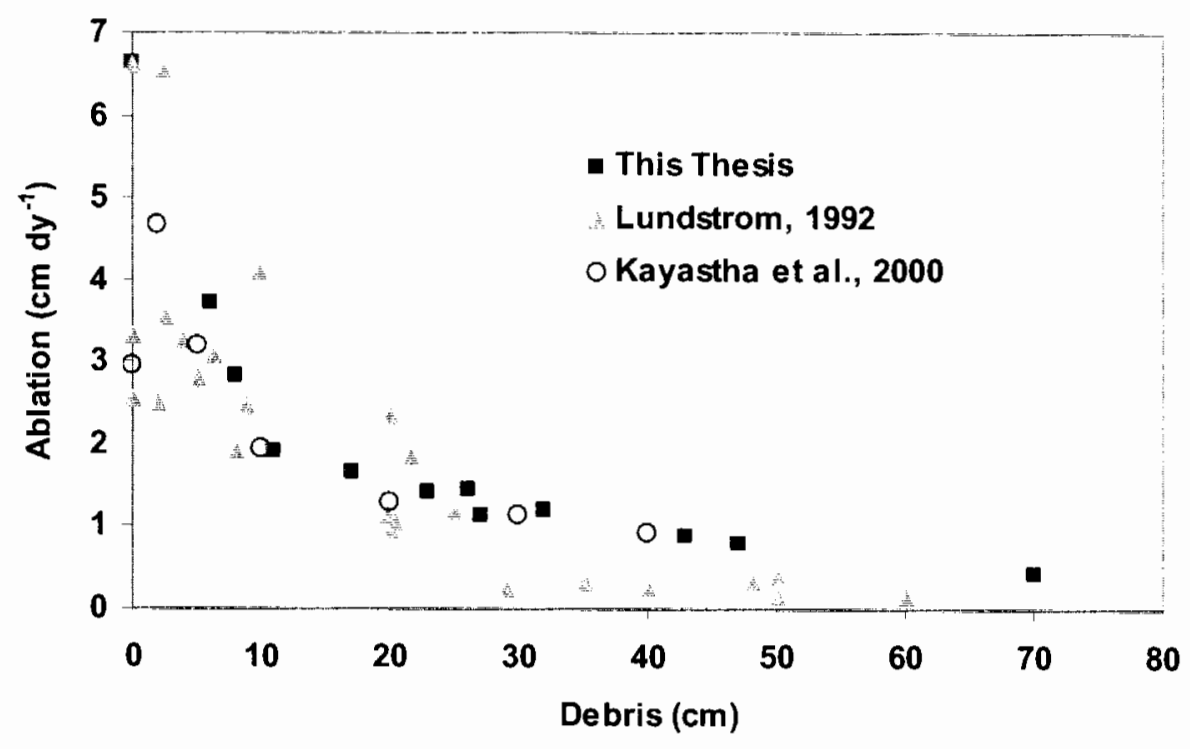

Figure 20. Ablation rates from this study, Lundstrom (1992) at Eliot Glacier, and Kayastha et al. (2000) at the Khumbu Glacier, Nepal, in relation to debris thickness. 


\section{ICE THICKNESS}

\section{Introduction}

This chapter combines the repeated elevation surveys of two transverse elevation profiles with ground-penetrating radar (GPR) to quantify changes in ice thickness over time. From these elevation profiles and my measurements, I quantify the thinning rate over time, and from the GPR data, I estimate the remaining ice volume in the lower glacier. GPR has been used on a number of glaciers, both clean and debris-covered, to determine ice depth (Narod and Clarke, 1994; Fountain and Jacobel, 1997; Gades et al., 2000). Thickness data is also important for the velocity analysis (Chapter 6).

\section{Methods}

In 1940, the Mazamas established two transverse profiles across the ablation zone of Eliot Glacier to make repeated measures of glacier elevation (Figure 21). By 1968 the glacier had retreated beyond the lower profile (A) and measurements at the upper profile (B) were discontinued in 1982. I re-measured the B-Profile to measure the rate of thinning since 1982. Unfortunately, the only marker left in the field was a boulder on the eastern moraine that has a pipe drilled into it and is painted with a yellow "A." I used Mazamas field notes (Matthes and Phillips, 1943; Mason, 1954; Handewith, 1959; Dodge, 1964, Dodge, unpublished) and a GPS to reconstruct the position of the remaining points (Table 8). 


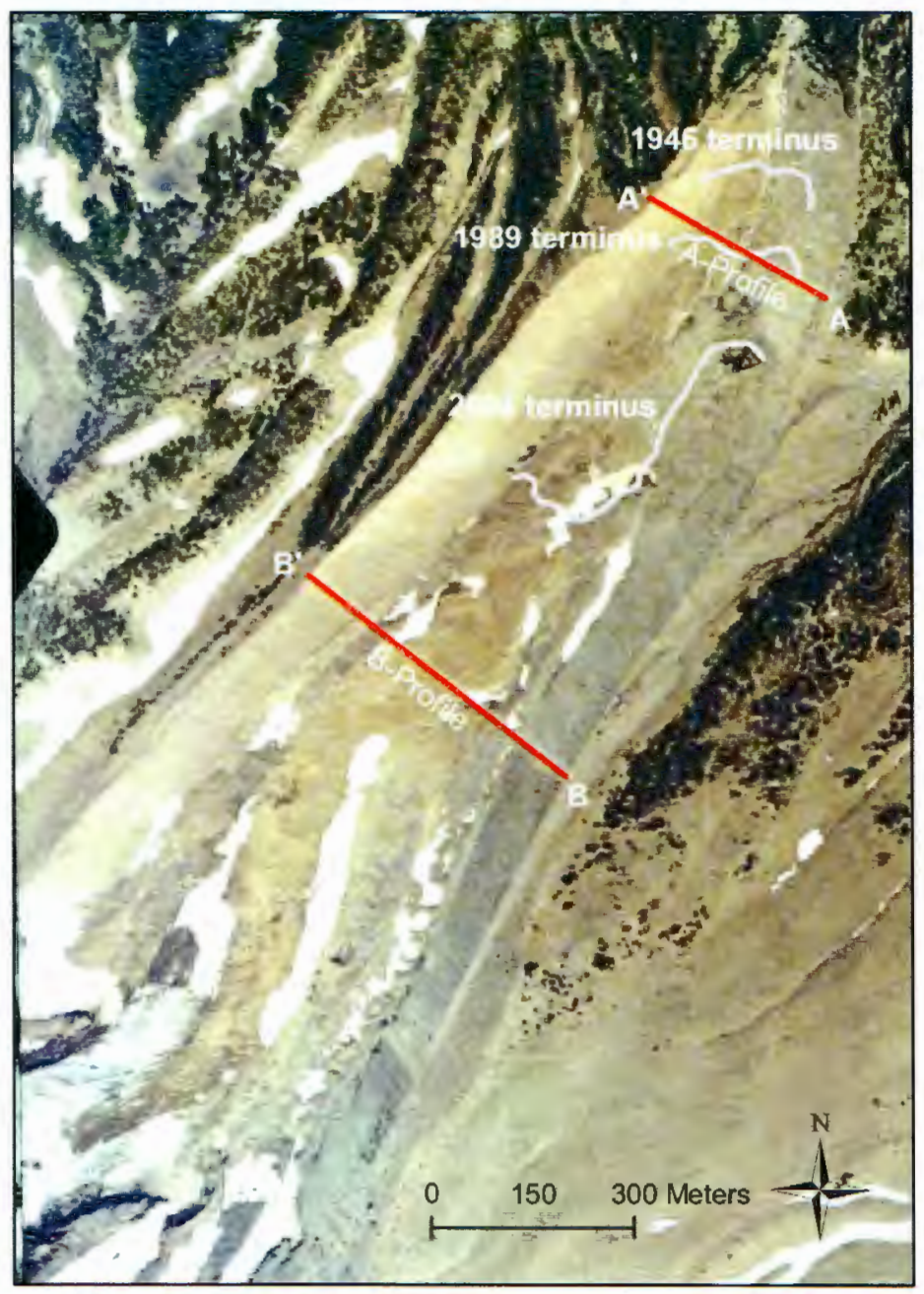

Figure 21. Locations of A and B-profiles

For the A-profile the Mazamas measured the elevation of the A boulder as $1953.77 \mathrm{~m}$ and the A' boulder $1947.37 \mathrm{~m}$ (Dodge, unpublished), with a separation distance of $314 \mathrm{~m}$ (Table 8 ). The GPS elevation I measured for the A boulder is $1942.30 \mathrm{~m}$. The $11.5 \mathrm{~m}$ between the Mazamas and my elevation is probably a result of different datums. I subtracted $11.5 \mathrm{~m}$ from the Mazamas A' elevation resulting in $1936 \mathrm{~m}$ and surveyed a line to the western moraine looking for a spot with that elevation. The boulder selected was $312.2 \mathrm{~m}$ from $\mathrm{A}$ and within $2 \mathrm{~m}$ of the Mazamas 
value. Given the erosion along the moraines observed in the field and from photo comparisons with historic images, a $2 \mathrm{~m}$ offset is well within reason.

Recreating the B-profile was more difficult because of the lack of benchmarks. I used a GPS to find the elevation of B' and B after applying the $11.5 \mathrm{~m}$ offset. The final B-profile elevation differences were less than $8 \mathrm{~m}$. Once the profiles were established, the valley floor/glacier surface was measured at $\sim 25 \mathrm{~m}$ intervals by the assistant carrying a rod and prism.

Table 8. Elevation profile reconstruction data

\begin{tabular}{|c|c|c|c|c|c|c|c|}
\hline \multirow[b]{2}{*}{ Point } & \multicolumn{2}{|c|}{ Mazama } & \multicolumn{2}{|c|}{ This Thesis } & \multirow{2}{*}{$\begin{array}{c}\text { Location } \\
\text { (UTM NAD } \\
27 \text { ) } \\
\end{array}$} & \multirow[b]{2}{*}{$\begin{array}{c}\text { Difference } \\
(\mathrm{m})\end{array}$} & \multirow[b]{2}{*}{ Offset $(\mathrm{m})$} \\
\hline & $\begin{array}{l}\text { Elev. } \\
(\mathrm{m})\end{array}$ & $\begin{array}{l}\text { Distance } \\
(\mathrm{m})\end{array}$ & $\begin{array}{c}\text { Elev. } \\
(\mathrm{m})\end{array}$ & $\begin{array}{c}\text { Distance } \\
\text { (m) }\end{array}$ & & & \\
\hline A & 1953.77 & - & 1942.30 & - & $\begin{array}{c}5027654.9 \mathrm{~N} \\
605087.6 \mathrm{E}\end{array}$ & 11.47 & 0.00 \\
\hline$A^{\prime}$ & 1947.37 & 313.9 & 1933.07 & 312.1 & $\begin{array}{c}5027809.8 \mathrm{~N} \\
604817.1 \mathrm{E}\end{array}$ & 14.30 & 2.83 \\
\hline B & 2089.10 & - & 2070.27 & - & $\begin{array}{c}5026949.8 \mathrm{~N} \\
604691.5 \mathrm{E}\end{array}$ & 18.83 & 7.36 \\
\hline $\mathrm{B}^{\prime}$ & 2087.88 & 478.5 & 2071.00 & 482.5 & $\begin{array}{c}5027244.9 \mathrm{~N} \\
604310.0 \mathrm{E}\end{array}$ & 16.88 & 5.41 \\
\hline
\end{tabular}

With the guidance and assistance of Dr. Rickard Pettersson from St. Olaf College, I conducted an ice depth survey of the debris-covered portion of the glacier. The GPR was a homemade backpack variety with a Tektronix THS-720 oscilloscope receiver, capable of delivering one trace per second to a computer. The transmitter was a monopulse avalanche-transistor transmitter (Narod and Clarke, 1994) with a nominal center frequency of $10 \mathrm{MHz}$. Our plan was to make transverse profiles at 100 $\mathrm{m}$ intervals starting at stake 12 . Unfortunately, because of problems with traveling over the debris, with the radar, and a relatively short time window, we only completed six profiles in a zig-zag pattern down the glacier. None of these profiles stretched 
entirely across the glacier. The data was later processed by Dr. Pettersson using a Butterworth filter with cutoff frequencies of 5 and $25 \mathrm{MHz}$, which eliminated low and high frequency "noise." The profiles were "migrated" to correct for the non-vertical travel path through the glacier, as a result of antenna separation.

\section{Results}

Errors on the elevation surveys were not recorded. Errors resulting from the total station are assumed to be less than $10 \mathrm{~cm}$, as indicated by numerous velocity surveys (Chapter 6). I estimate vertical error to be between 0.1 and $1.0 \mathrm{~m}$ because of the varying topography of the elevation profiles. Errors of $\leq 1.0 \mathrm{~m}$ are likely as accurate as past surveys and illustrate thinning. Since the profiles were first surveyed in 1940, the glacier has retreated and thinned. The A-profile, once spanning the glacier, now spans areas that possibly contain stagnant ice $350 \mathrm{~m}$ downvalley of the terminus (Figure 22). The 2005 elevation at the A-profile is approximately $1890 \mathrm{~m}$ in the center and $1904 \mathrm{~m}$ at the lateral margins. Debris thicknesses at the lower profile are $>2 \mathrm{~m}$ as I discovered when attempting to dig to the ice surface. During the 2005 field season a small ice face appeared in the vicinity of the A-profile indicating buried ice pockets. Visual estimates of the debris cover over the exposed ice faces confirm that debris thicknesses $>2 \mathrm{~m}$. However, direct measurements were not possible as the exposed ice faces were too steep to approach. The upper (B) profile's elevation is approximately $2005 \mathrm{~m}$ in the center of the glacier and $2015 \mathrm{~m}$ at the lateral margins (Figure 22). Debris thicknesses at the upper profile are about $30 \mathrm{~cm}$ in the center of the glacier and $40 \mathrm{~cm}$ on the lateral margins. 

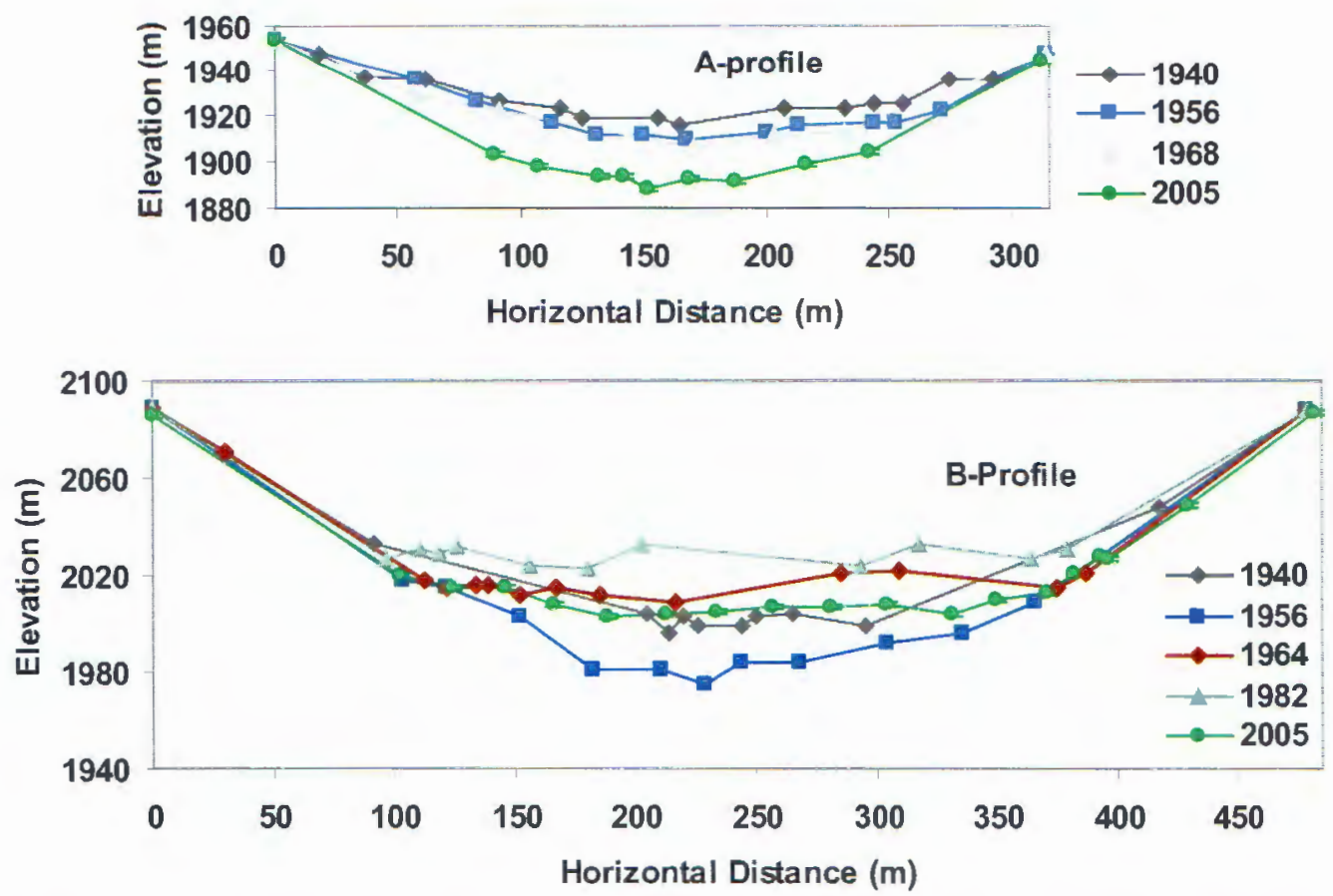

Figure 22. Elevation profiles originally surveyed by Mazamas. Error bars represent 1 $\mathrm{m}$ error in both directions (up and down) and are nearly encompassed by the size of the dots.

The GPR survey produced the first detailed ice thickness map of lower Eliot Glacier. Ice thicknesses decrease as one travels down-glacier from the ELA as well as laterally from the glacier centerline (Figure 23, Figure 24). The thickest ice was about $90 \mathrm{~m}$ thick located near stake 11 . The thinnest ice sounded was about $35 \mathrm{~m}$ thick, the farthest down-glacier point recorded. I estimated the volume of ice contained in the GPR-surveyed portion of this study at $9.504 \times 10^{6} \mathrm{~m}^{3}$ by subtracting glacier bed elevations from glacier surface elevations. 


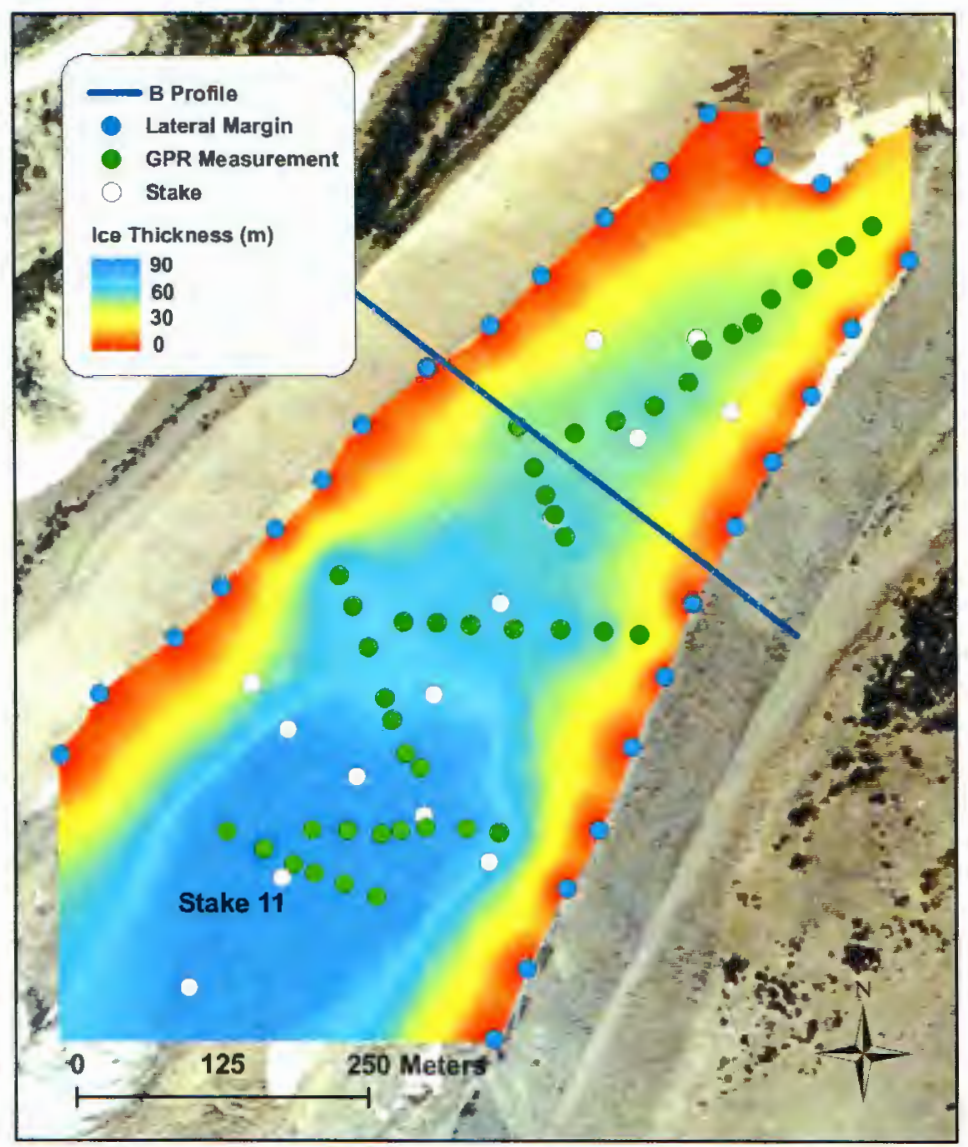

Figure 23. Inverse distance weighting extrapolation of ice depths. Lateral margins are assumed to be zero ice thickness. 


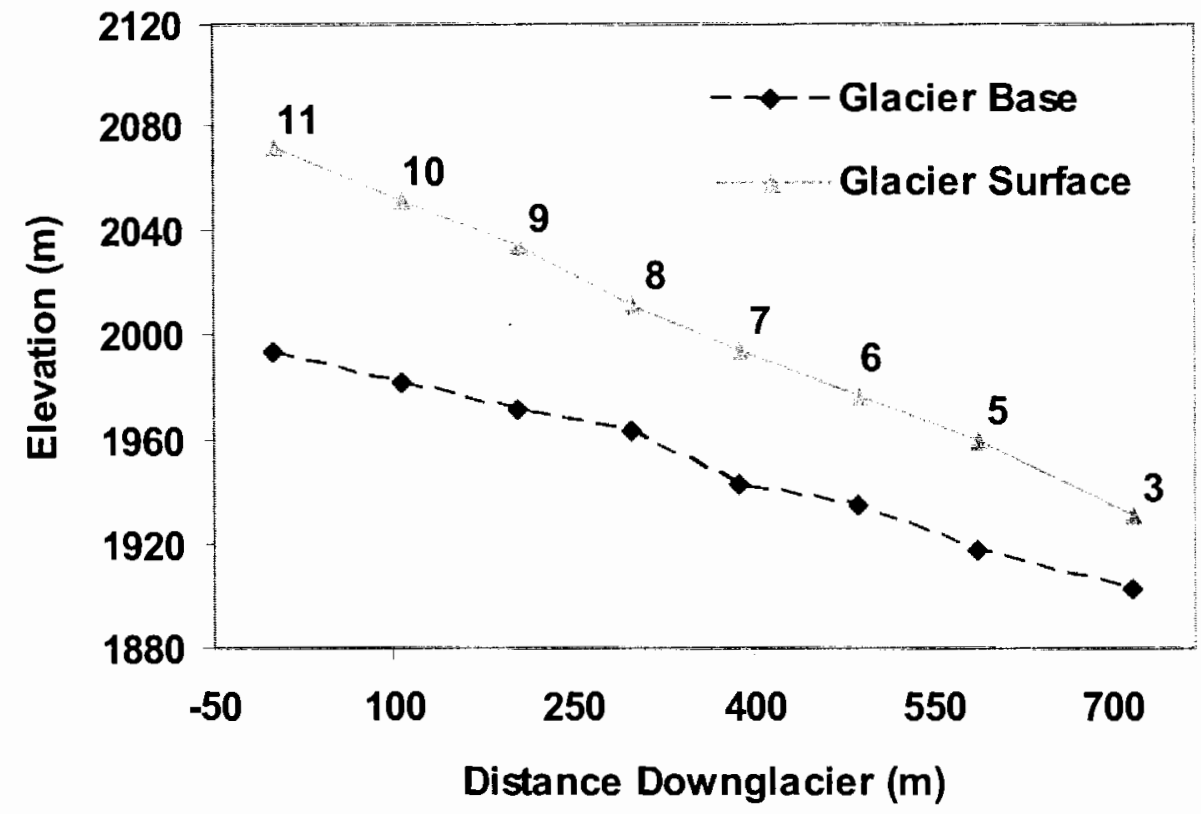

Figure 24. Longitudinal profile along the glacier's centerline of flow interpolated from the GPR with stakes labeled along the glacier surface. Vertical exaggeration is about 2:1.

\section{Analysis}

Since the last survey of the A-profile in 1968 the profile has thinned about 15 $\mathrm{m}$ at the edge of the glacier and about $20 \mathrm{~m}$ in the center. The current elevation of the B-profile is remarkably close to that in 1940 . The 1956 profile showed that the glacier had thinned about 15-20 m since 1940, similar to the 1982-2005 period (Figure 25). Between 1956 and 1982 the glacier thickened by $50 \mathrm{~m}$. Dodge (1964) described an "ice wave" that appeared to be moving down-glacier in 1958 (Figure 26). We now recognize this as a kinematic wave, common to steeply sloping glaciers (Meier, 1962).

The thinning since 1982 has averaged about $1.0 \pm 0.02 \mathrm{~m} \mathrm{a}^{-1}$, with $\sim 0.7 \mathrm{~m} \mathrm{a}^{-1}$ on the lateral margins and $\sim 1.3 \mathrm{~m} \mathrm{a}^{-1}$ in the center of the glacier. In addition to the Lundstrom et al. (1993) calculated an average thinning of $0.8 \mathrm{~m} \mathrm{a}^{-1}$ between 1984 and 
1989 across the debris-covered portion of the glacier. My thinning value of $\sim 1.0 \mathrm{~m}$ $\mathrm{a}^{-1}$ at the B-Profile from 1982 to 2005 may be indicative of an increased thinning rate since the late 1980s. My recorded ablation data from the B-profile vicinity shows approximately $1.2 \mathrm{~m}$ of annual ablation, consistent with the average ablation rate at the center of the glacier.

An estimate of the glacier's surface elevation in 1901 is possible by the examination of four H.F. Reid photographs (Appendix D), and it appears that the glacier was over $100 \mathrm{~m}$ thick at the B-Profile (Figure 27). The glacier thinned steadily until 1956 when it reached a low of about $27 \mathrm{~m}$ before thickening to about $66 \mathrm{~m}$ in 1968. It remained this thickness for six years, at which point it began to thicken again, reaching $73 \mathrm{~m}$ by 1982 . Since then, however, it has thinned to $51.5 \mathrm{~m}$.

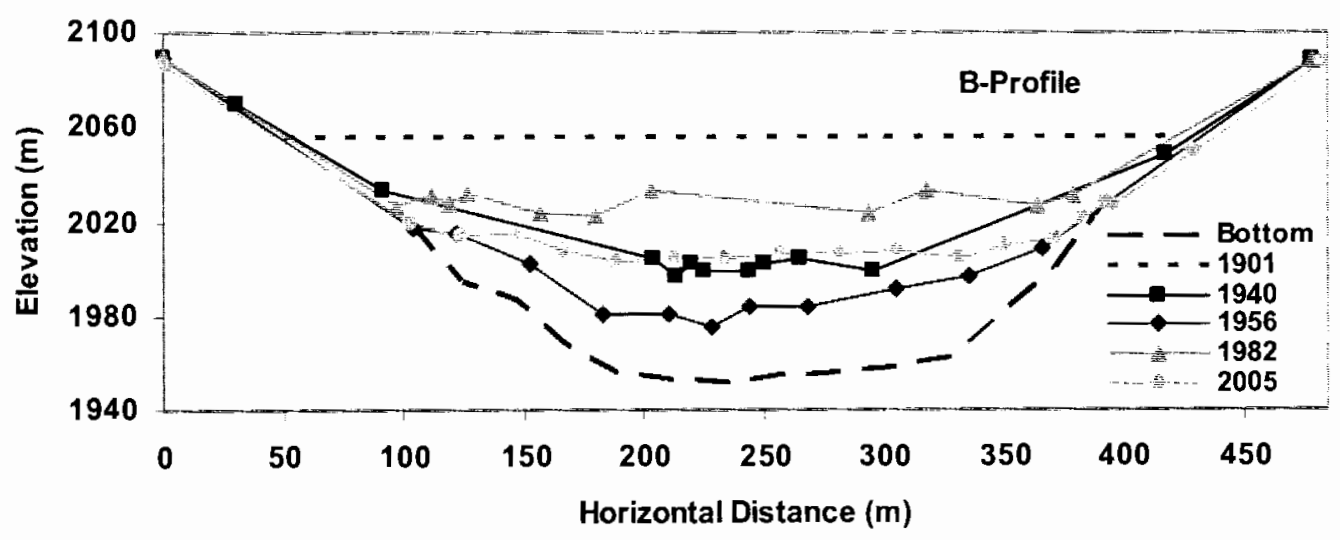

Figure 25. B-profile with glacier base from inverse-distance weighted (IDW) map (Figure 23). The elevation of the glacier bottom was estimated by collecting depths along IDW graphic at $20 \mathrm{~m}$ intervals along the profile. 


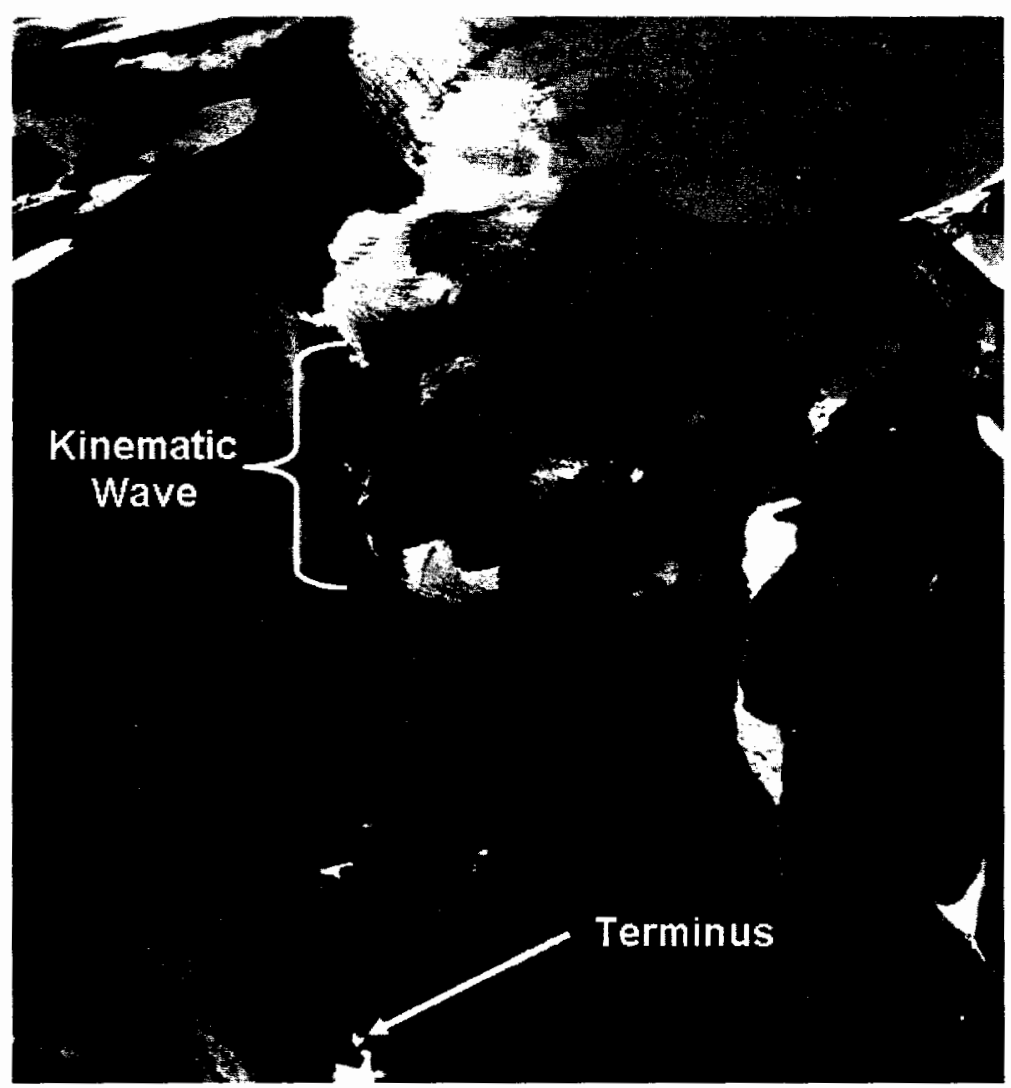

Figure 26. 1956 oblique aerial photograph of Eliot Glacier showing the kinematic wave that resulted from the decrease in temperatures and increase in accumulation season precipitation in the early 1940s (H. Ackroyd photo, courtesy Mazamas). 


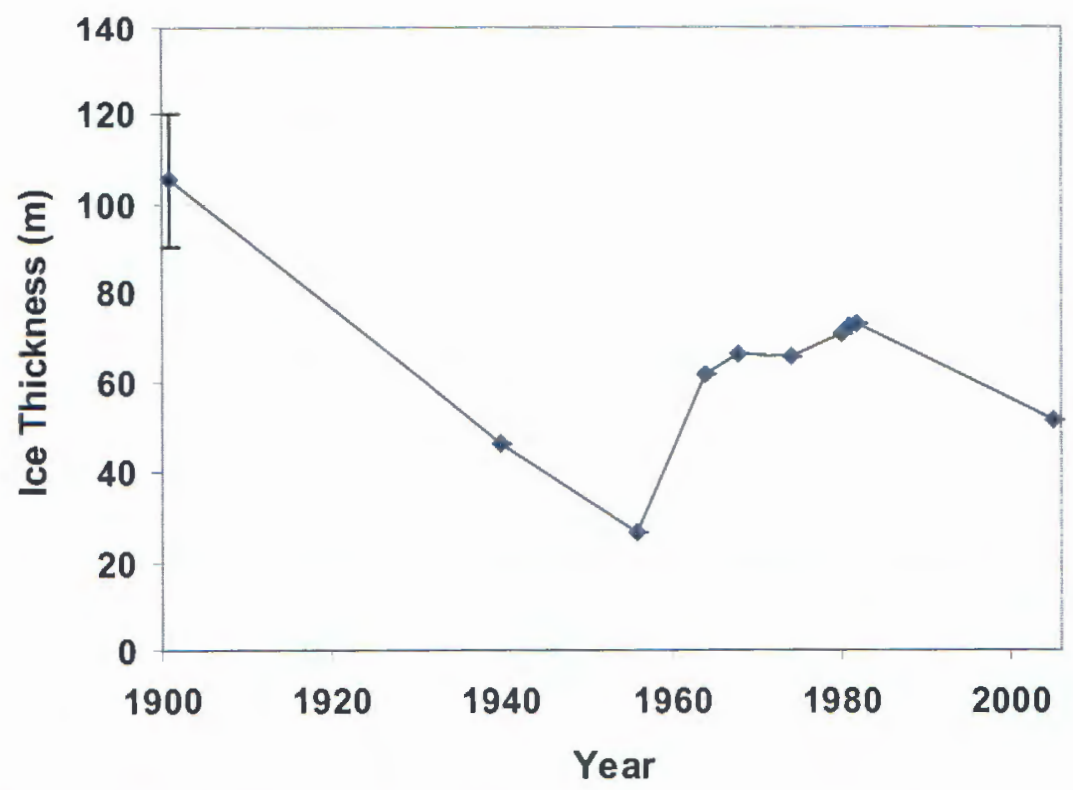

Figure 27. lce thickness with time. 1901 thickness is estimated from four H.F. Reid photographs. From: Mazamas surveys and this study (2005).

As previously mentioned, we were unable to complete an entire transverse profile with the GPR. However, the six profiles (Figure 28) are still valuable illustrations of the glacier bed. Profile 3 displays an internal reflector layer that is probably debris. Unfortunately, my survey was not close enough to the lateral margin of the glacier to determine if this layer reached the glacier bottom. 


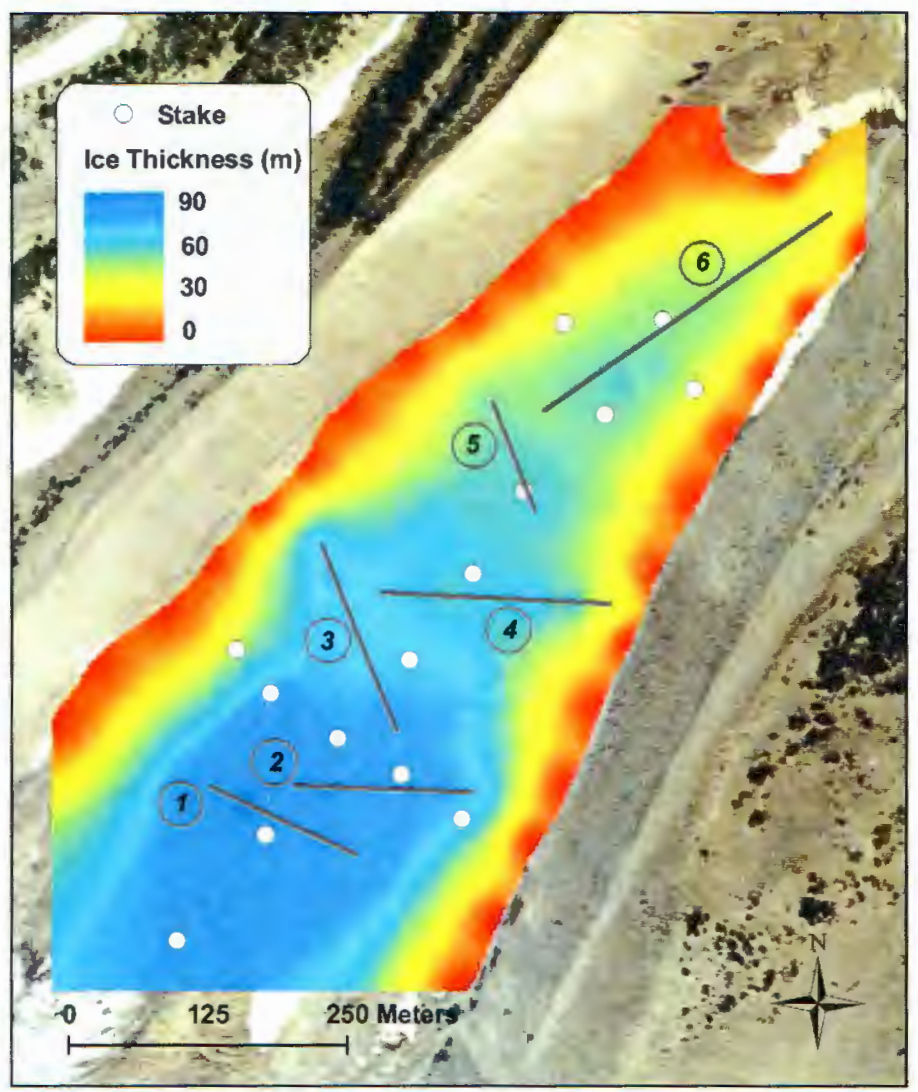

Figure 28. GPR image based on six profile lines. Numbers refer to profiles shown in (Figure 29). 

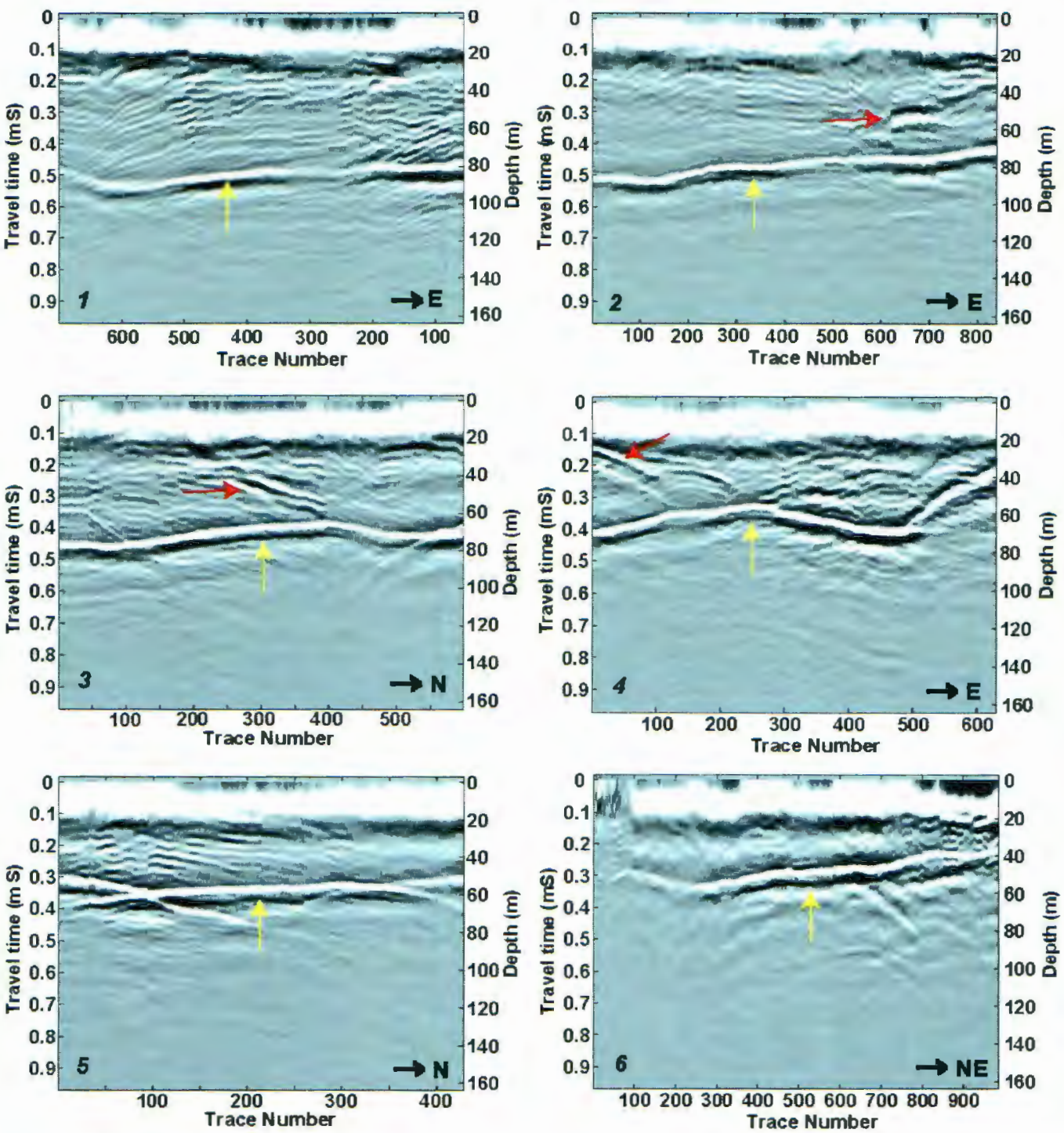

Figure 29. Six GPR profiles with nearest cardinal directions labeled. Yellow arrows indicate bottom of the glacier. Red arrows indicate possible internal reflection "layers" on profiles 2,3 , and 4 . 


\section{SURFACE VELOCITIES}

\section{Introduction}

The spatial and temporal variation in surface velocities is important for understanding the glacial history and effect on debris thickness. This chapter summarizes my methods of velocity measurements, results, and compares to past measurements.

\section{Methods}

Four control points, all boulders, were established for the velocity survey (Figure 30). Two were established $170 \mathrm{~m}$ apart on the western moraine, one for the theodolite location and the other defined the reference (zeroset) datum. Two were established across the glacier on the eastern moraine, one at the moraine crest ( $490 \mathrm{~m}$ away) and one near the base. Both of these were used to estimate atmospheric refraction. I used a Trimble GeoXT GPS unit on the moraine locations and recorded approximately 400 points at each moraine location which I then post-processed with the nearby Appleton, Washington Continuously Operating Reference Station (CORS) to accurately place my surveys into the UTM NAD 27 coordinate system. The theodolite was a Sokkia Set 4B laser theodolite total station, positioned on the western moraine, to survey the stakes on the glacier. I measured the angles from the backsight (zero set) to the two control boulders on the eastern moraine a few times during each survey. Angle offsets from the start of the survey at the control boulders were converted to linear errors, $E(\mathrm{~m})$, by, 


$$
E=\frac{A}{360} \pi H
$$

where $A$ is the angle offset (degrees) and $H$ is the horizontal distance to the control prism $(\mathrm{m})$. The magnitudes of the errors at the control boulders were scaled by distance from the total station to the targets on the glacier. For example, an error of $2.0 \mathrm{~cm}$ at the eastern moraine prism (whichever produced the larger error between the base and crest prisms) would equate to a $1.0 \mathrm{~cm}$ error at a stake $245 \mathrm{~m}$ from the total station.

Angle and distance measurements with the theodolite were converted to $x, y, z$ locations. Horizontal velocities reflect movement in the horizontal direction rather than the down slope direction. Vertical velocity components, or emergence, $w_{z}$, are calculated following Paterson (1994),

$$
w_{z}=v_{z}+u_{s} \frac{\partial z}{\partial s}
$$

where $z$ represents the vertical coordinate and $s$ represents the horizontal coordinate. The vertical difference measured between the stake from the first and last surveys is $v_{\mathrm{Z}}, u_{s}$ is the horizontal flow speed of the stake, and $\partial z / \partial x$ the slope of the glacier at the stake. Slope of the glacier was calculated based on my $v_{z}$ measurements. Because $v_{z}$ measurements are contained within the $w_{z}$ component, I iterated (2) three times for each stake to produce the fixed point value. Vertical velocity components were only calculated for the annual survey because of the small magnitude of vertical movement. The errors associated with vertical displacement measurements were propagated (Baird, 1962) through (2) to obtain vertical velocity errors. 
Table 9. Survey control points. Coordinates are UTM NAD 27.

\begin{tabular}{lccr} 
Control Point & Easting & Northing & Elevation (m asl) \\
\hline Total Station & 604306.95 & 5027242.44 & 2076.23 \\
Zero Set & 604186.03 & 5027123.05 & 2099.04 \\
Moraine Crest & 604678.48 & 5026926.43 & 2078.03 \\
Moraine Base & 604605.93 & 5026986.98 & 2016.03
\end{tabular}

I used two different sets of targets on the glacier. The first set was prisms momentarily mounted on the PVC stakes, yielding an easting, northing, and elevation. The second set of targets was boulders on the ice surface to fill in gaps in the stake array (Figure 30). Prisms were placed at spots painted on each boulder. These targets yield only the horizontal displacement of the ice (easting, northing) because elevation (z) displacement is a mixture of ablation and strain. During the summer of 2004 , I surveyed the targets on a near-weekly basis (August $13^{\text {th }}$ through September $24^{\text {th }}$ ) for a total of six times. The glacier was surveyed a year later on July $28^{\text {th }}, 2005$ to determine the annual movement. 


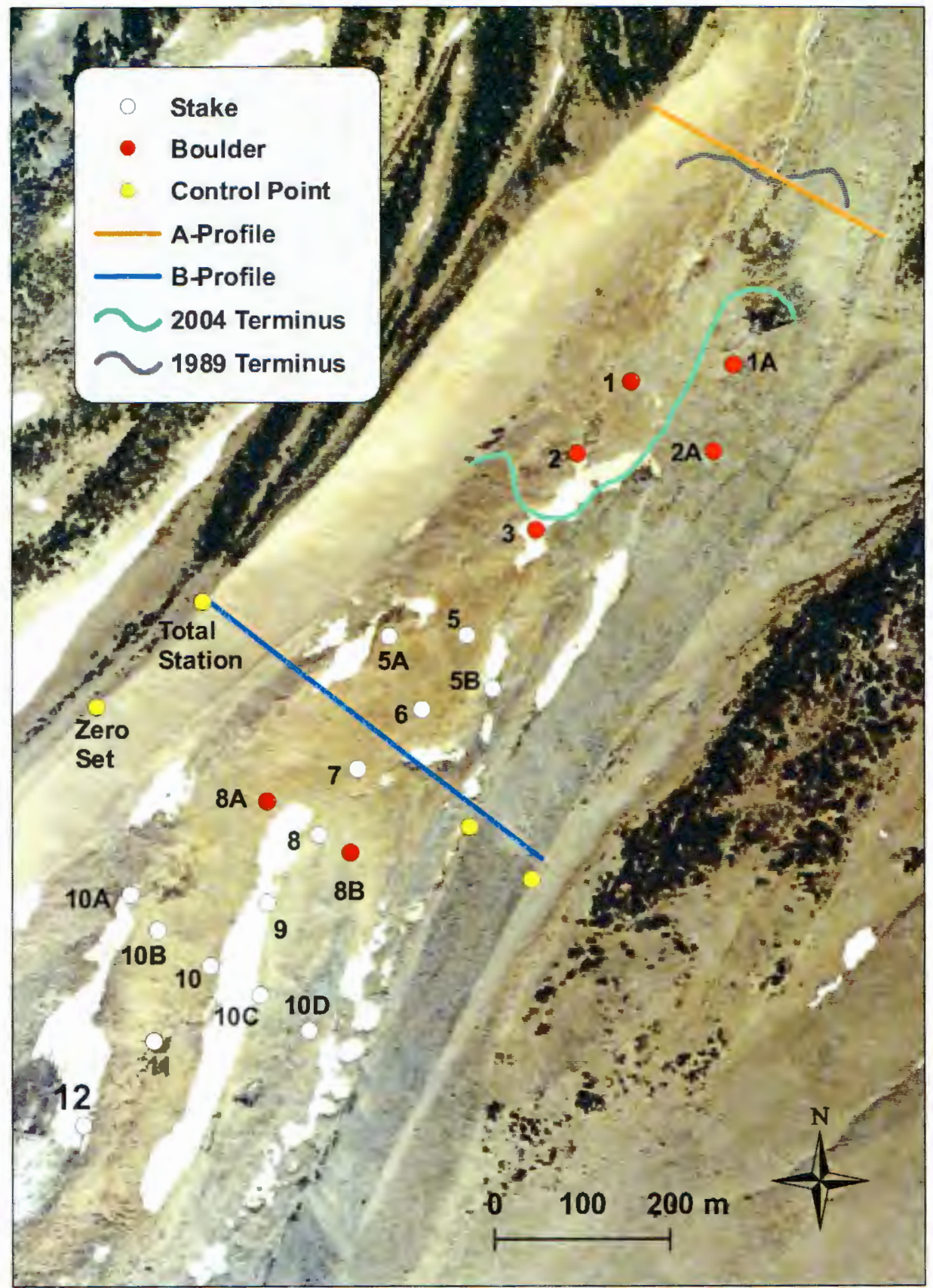

Figure 30. Map showing control points, survey points, and location of the total station theodolite.

I also made photogrammetric measurements from aerial photographs taken in 1989 and 2004 to examine long term movement. These aerial photographs were at a 1200 dots per inch (dpi) resolution that, once georeferenced to the Mount Hood North 
digital orthophoto quadrangle (DOQ), see Chapter 3, with ESRI ArcGIS software, allowed me to track boulder movements on the glacier surface.

\section{Results}

The accuracy in the positions of the stakes and boulders varied during survey sessions as well as between measurement periods (Appendix F). Errors are most likely a result of differences in atmospheric refraction related to air temperature differences along the line of sight and pressure differences (Mayo et al., 2004). All surveys other than the September $3^{\text {rd }}, 2004$ survey had errors that were lower than the weekly displacement of the upper stakes. Additionally, the annual survey's errors are within the displacement of all locations.

Table 10. Errors for individual locations during survey on 07.28.2005.

\begin{tabular}{cccccc} 
Location & $\begin{array}{c}\text { Horizontal Error } \\
(\mathrm{cm})\end{array}$ & $\begin{array}{c}\text { Vertical } \\
\text { Error }(\mathrm{cm})\end{array}$ & Location & $\begin{array}{c}\text { Horizontal Error } \\
(\mathrm{cm})\end{array}$ & $\begin{array}{c}\text { Vertical } \\
\text { Error }(\mathrm{cm})\end{array}$ \\
\hline 12 & 1.5 & 0.4 & 7 & 1.1 & 0.7 \\
11 & 0.7 & 0.0 & 6 & 0.7 & 0.8 \\
10 & 0.4 & 0.1 & 5 & 0.3 & 1.0 \\
$10 \mathrm{~A}$ & 0.7 & 0.3 & $5 \mathrm{~A}$ & 0.3 & 0.9 \\
$10 \mathrm{~B}$ & 0.7 & 0.2 & $5 \mathrm{~B}$ & 0.7 & 0.9 \\
$10 \mathrm{C}$ & 0.3 & 0.1 & 3 & 0.2 & 1.2 \\
$10 \mathrm{D}$ & 0.2 & 0.0 & 2 & 0.0 & 1.5 \\
9 & 1.0 & 0.4 & $2 \mathrm{~A}$ & 0.3 & 1.3 \\
8 & 1.2 & 0.6 & 1 & 0.5 & 1.6 \\
$8 \mathrm{~A}$ & 0.8 & 0.7 & $1 \mathrm{~A}$ & 0.9 & 1.5 \\
$8 \mathrm{~B}$ & 1.2 & 0.6 & & & \\
\hline
\end{tabular}

Surface velocities generally decrease down-glacier and laterally away from the centerline (Table 11). Velocities were highest at the uppermost stake (Stake 12) with $1.17 \pm 0.00 \mathrm{~m}$ of displacement over the six-week study period $\left(2.8 \pm 0.0 \mathrm{~cm} \mathrm{dy}^{-1}\right)$ and $7.52 \pm 0.02 \mathrm{~m}$ over the 350 -day study period $\left(7.85 \pm 0.02 \mathrm{~m} \mathrm{a}^{-1}\right.$ or $\left.2.15 \pm 0.00 \mathrm{~cm} \mathrm{dy}^{-1}\right)$ 
(Figure 32). Daily velocities were calculated by dividing displacement by total number of days and annual velocities were calculated by multiplying the daily velocities by 365 . Nearly all targets show faster velocities during the six-week study period than average annual values. Over the six weeks $(\sim 11.5 \%$ of the year) between 7 and $19 \%$ of total movement occurred. Velocities decreased to near zero at the lowest targets nearest the terminus of the glacier (i.e., boulders 1, 2, 1A, and 2A). Boulders 1 and 2 moved $6.3 \pm 0.5 \mathrm{~cm}$ and $9.8 \pm 0.0 \mathrm{~cm}$, respectively, over the 350 days. Boulders $1 \mathrm{~A}$ and $2 \mathrm{~A}$ lie on an arm at Eliot's terminus that slopes steeply northwest, influencing the movement of these boulders. These data are ignored because the boulders are most likely sliding down the ice. 
Table 11. Displacement and velocity data for individual locations. ANNUAL $=350$ day study period. SUMMER=6-week study period.

ANNUAL

SUMMER

\begin{tabular}{|c|c|c|c|c|c|}
\hline Site & Total horiz. $(\mathrm{m})$ & Avg. $\left(\mathrm{cm} \mathrm{dy}^{-1}\right)$ & Total vert. (m) & Total (m) & Avg. $\left(\mathrm{cm} \mathrm{dy}^{-1}\right)$ \\
\hline$\overline{12}$ & $7.52 \pm 0.02$ & 2.15 & $0.05 \pm 0.00$ & $1.17 \pm 0.00$ & 2.72 \\
\hline 11 & $6.93 \pm 0.01$ & 1.98 & $0.10 \pm 0.00$ & $1.11 \pm 0.00$ & 2.58 \\
\hline 10 & $5.63 \pm 0.00$ & 1.61 & $0.04 \pm 0.00$ & $0.62 \pm 0.01$ & 1.45 \\
\hline $10 \mathrm{~A}$ & $3.79 \pm 0.01$ & 1.08 & $-0.03 \pm 0.00$ & $0.63 \pm 0.01$ & 1.47 \\
\hline $10 \mathrm{~B}$ & $4.85 \pm 0.01$ & 1.38 & $0.00 \pm 0.00$ & $0.97 \pm 0.01$ & 2.27 \\
\hline $10 \mathrm{C}$ & $4.10 \pm 0.00$ & 1.17 & $0.02 \pm 0.00$ & $0.72 \pm 0.00$ & 1.68 \\
\hline 10D & $3.49 \pm 0.00$ & 1.00 & $0.03 \pm 0.00$ & $0.58 \pm 0.01$ & 1.36 \\
\hline 9 & $3.75 \pm 0.01$ & 1.07 & $0.00 \pm 0.00$ & $0.53 \pm 0.01$ & 1.23 \\
\hline 8 & $3.19 \pm 0.01$ & 0.91 & $0.00 \pm 0.00$ & $0.47 \pm 0.01$ & 1.09 \\
\hline $8 \mathrm{~A}$ & $2.75 \pm 0.01$ & 0.78 & - & $0.36 \pm 0.01$ & 0.85 \\
\hline $8 \mathrm{~B}$ & $3.40 \pm 0.01$ & 0.97 & - & $0.47 \pm 0.01$ & 1.10 \\
\hline 7 & $2.17 \pm 0.01$ & 0.62 & $-0.01 \pm 0.01$ & $0.36 \pm 0.01$ & 0.85 \\
\hline 6 & $1.41 \pm 0.01$ & 0.40 & $0.01 \pm 0.01$ & $0.47 \pm 0.03$ & 1.10 \\
\hline 5 & $1.34 \pm 0.00$ & 0.38 & $0.02 \pm 0.01$ & $0.22 \pm 0.03$ & 0.51 \\
\hline $5 \mathrm{~A}$ & $1.35 \pm 0.00$ & 0.39 & $0.00 \pm 0.01$ & $0.10 \pm 0.02$ & 0.24 \\
\hline $5 \mathrm{~B}$ & $0.81 \pm 0.01$ & 0.23 & $0.01 \pm 0.01$ & $0.20 \pm 0.04$ & 0.46 \\
\hline 3 & $0.70 \pm 0.00$ & 0.20 & - & $0.08 \pm 0.04$ & 0.19 \\
\hline 2 & $0.10 \pm 0.00$ & 0.03 & - & $0.15 \pm 0.05$ & 0.35 \\
\hline $2 \mathrm{~A}$ & $0.21 \pm 0.00$ & 0.06 & - & $0.09 \pm 0.06$ & 0.22 \\
\hline 1 & $0.06 \pm 0.01$ & 0.00 & - & $0.12 \pm 0.05$ & 0.29 \\
\hline IA & $0.66 \pm 0.01$ & 0.19 & - & $0.07 \pm 0.06$ & 0.17 \\
\hline
\end{tabular}




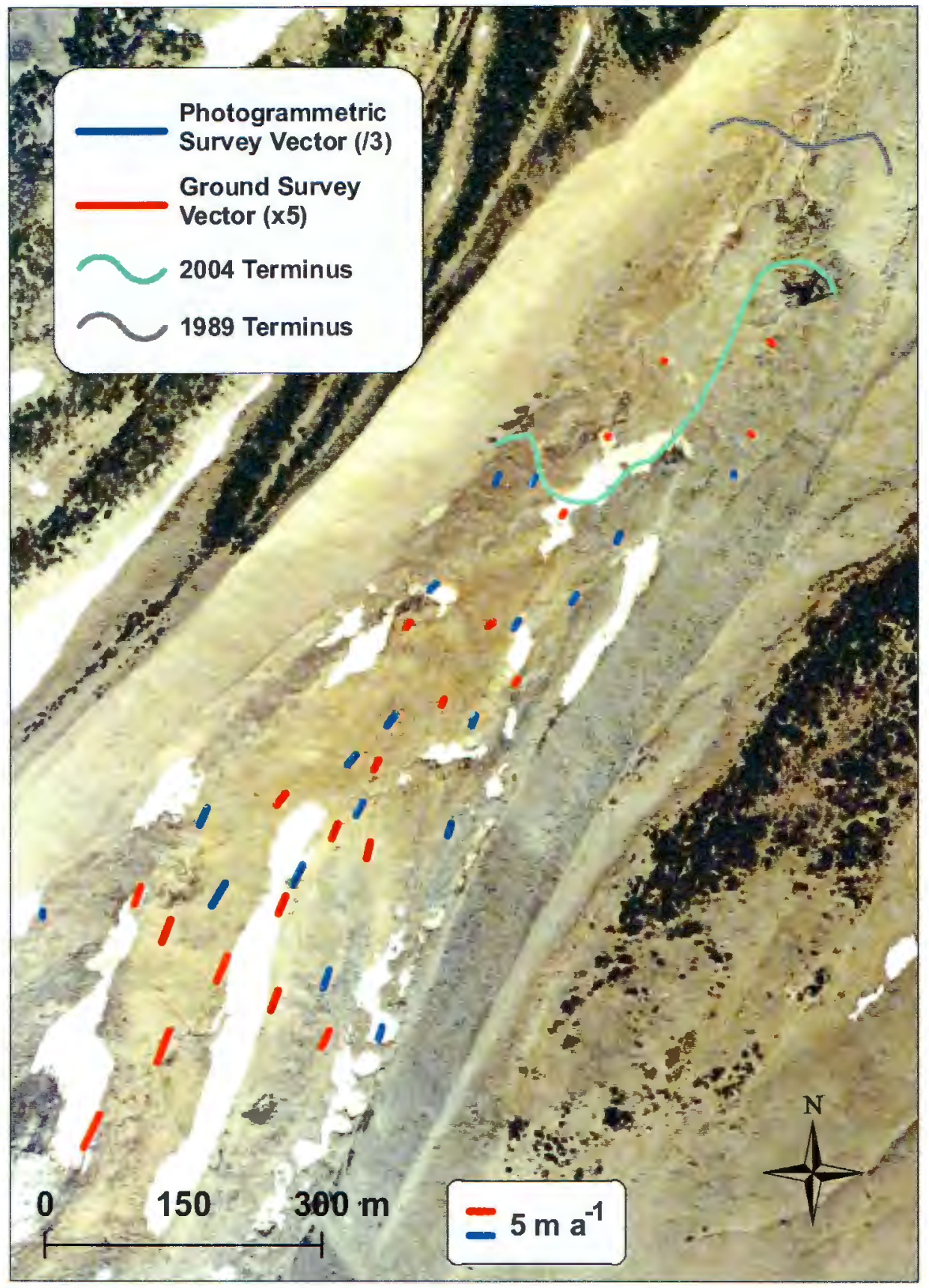

Figure 31. Ground survey vectors multiplied by 5 and photogrammetric vectors divided by 3 to give 5 -year displacements. 


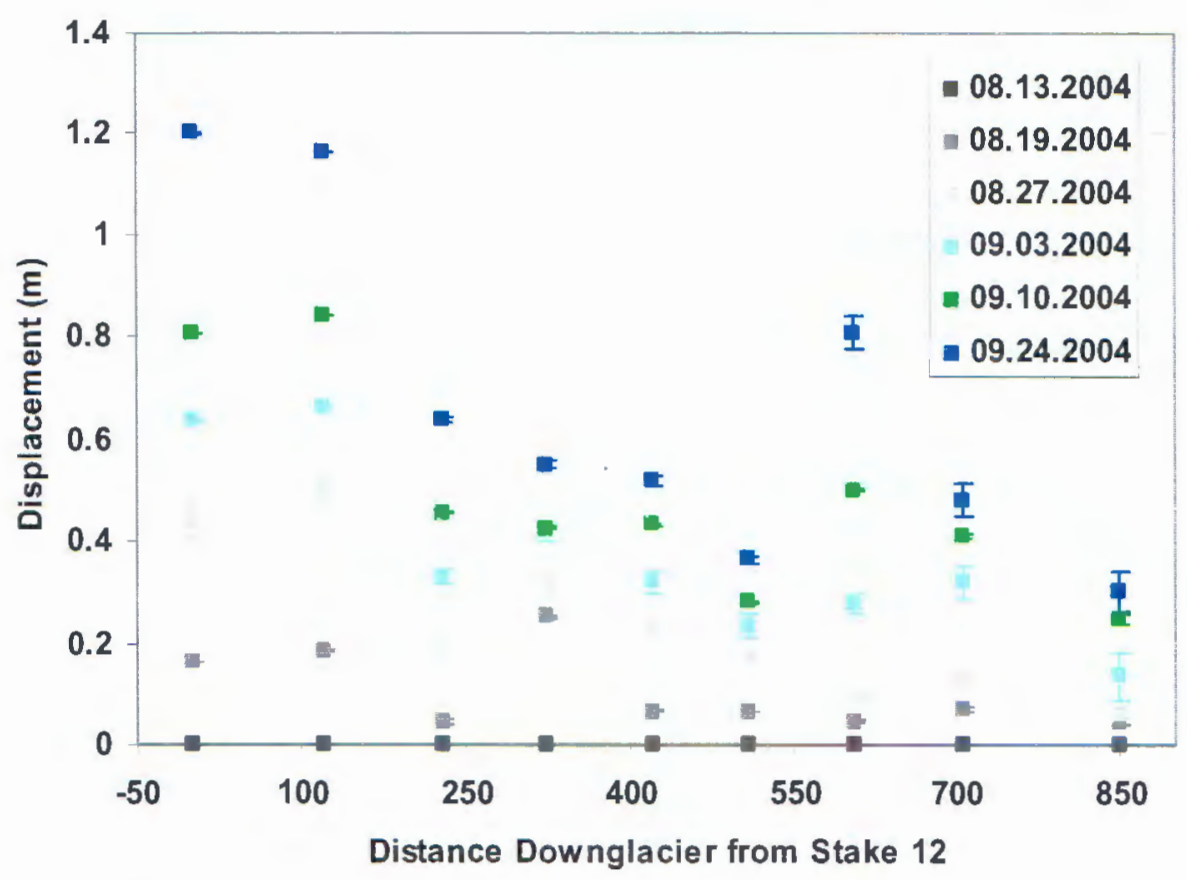

Figure 32. Displacements at locations above active terminus during summer study period. Error bars represent survey uncertainties for total each displacement value.

\section{Analysis}

Vertical velocity components do not follow an obvious trend in the downglacier direction, increasing from $4.7 \pm 0.4 \mathrm{~cm} \mathrm{a}^{-1}$ at stake 12 to $10.4 \pm 0.0 \mathrm{~cm} \mathrm{a}^{-1}$ at stake 11 , before decreasing until stake 9 , at which point vertical velocity increases in the down-glacier direction to $1.6 \pm 1.1 \mathrm{~cm} \mathrm{a}^{-1}$ at stake 5 (Figure 33). Stakes 7, 8, and 9 displayed almost no emergence. 


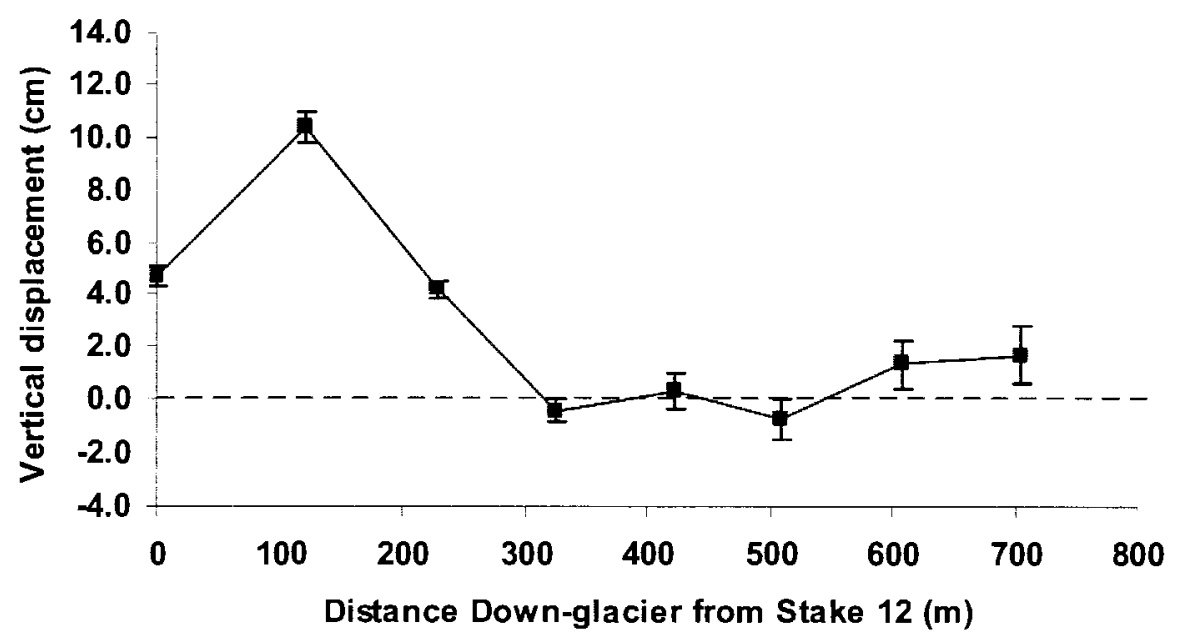

Figure 33. Vertical displacements along centerline of flow. Positive displacement indicates emergence and negative displacement indicates submergence.

Velocities decrease in the down-glacier direction (Figure 34b), with the exceptions of stakes 5 and 6 . Stake 6 appears to be an outlier because over the 6 -week summer only $7 \%$ of its total movement occurred. During the period of August $21^{\text {st }}$ $24^{\text {th }}, 2004$ there was over $14 \mathrm{~cm}$ of rainfall and an ephemeral supraglacial stream worked across the location of stake 6 . As a result, stake 6 was pressed and bent by a number of large boulders that I was unable to move. I believe this bend in the stake caused the subsequent surveys of stake 6 to contain higher errors than those associated with the rest of the surveys. The annual movement plot more accurately portrays the movement pattern of stake 6 (Figure 34a). 
Distance Downglacier from Stake $12(\mathrm{~m})$
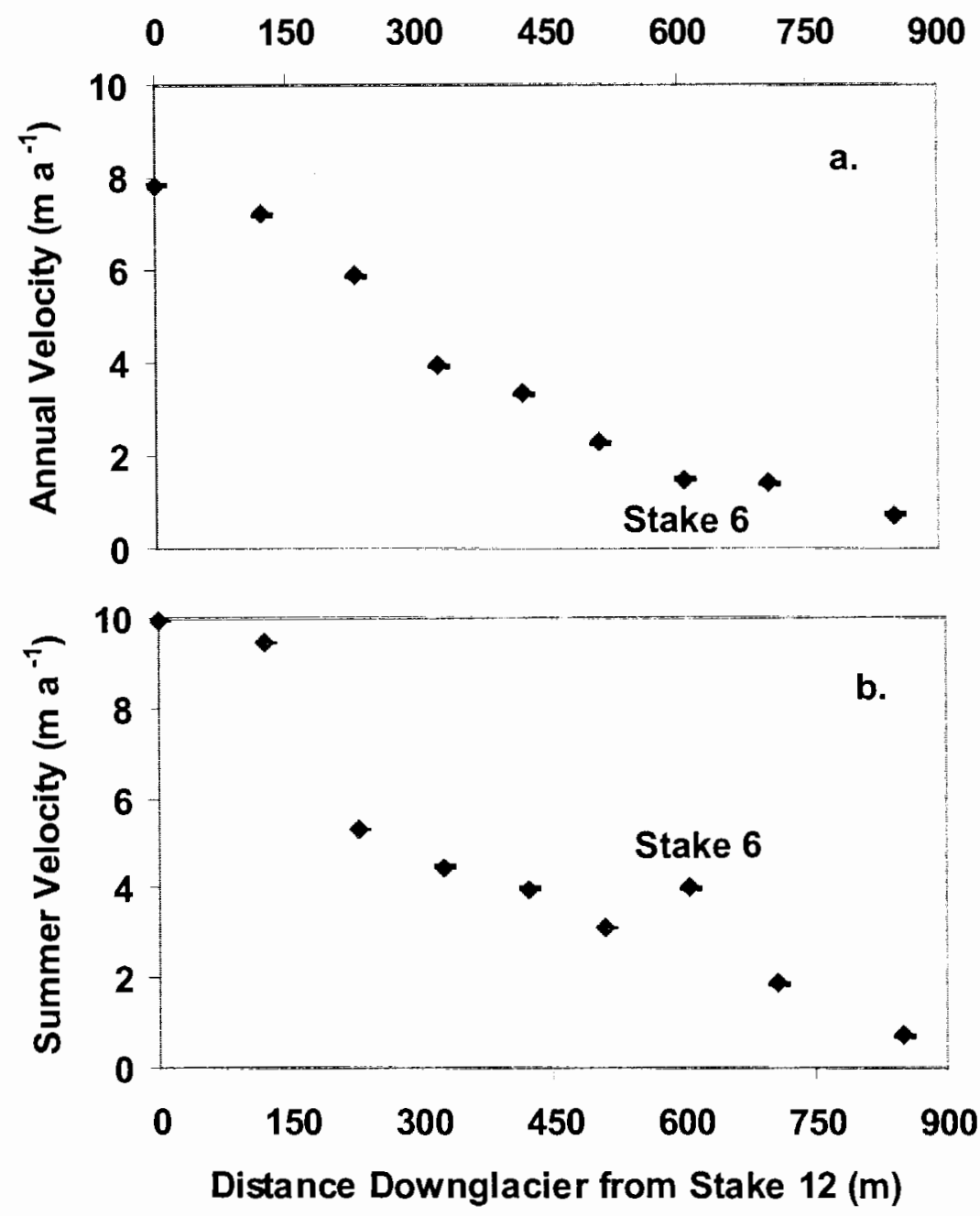

Figure 34. Annual (a) and summer (b) velocities, plotted against distance downglacier along the central flowline. Errors for both surveys are encompassed by the size of the dots.

I used the root mean square errors (RMSE) calculated by ArcMap to assess errors on the photogrammetric measurements. A first order polynomial algorithm with four control points produced an RMSE for the 2004 photo of $5.1 \mathrm{~m}$. I georeferenced the 1989 photo to the 2004 photo with an RMSE of $2.9 \mathrm{~m}$. 
Displacements of boulders over 15 years exhibit slightly higher annual velocities than the ground survey (Figure 35).

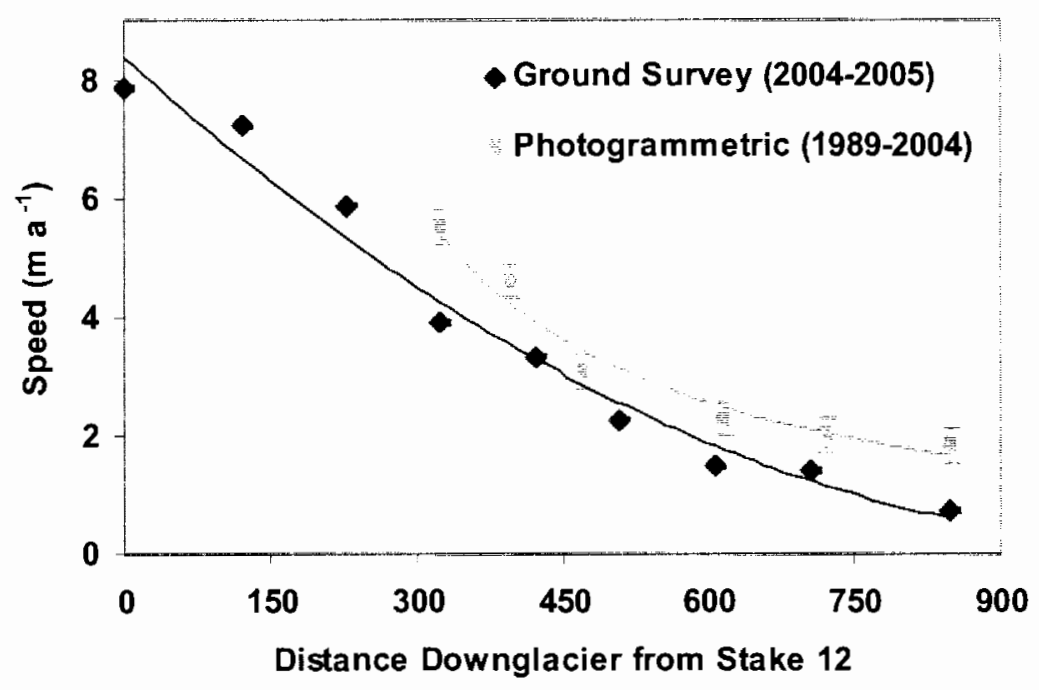

Figure 35. Annual speeds for ground and photogrammetric surveys. No photogrammetric measurements were made in the upper $300 \mathrm{~m}$ of the glacier. Error bars on the annual ground survey are encompassed by the size of the dots.

Surface velocities at the B-profile decreased from about $2.4 \mathrm{~m} \mathrm{a}^{-1}$ in 1941-1942 (Matthes and Phillips, 1943) to $1.4 \mathrm{~m} \mathrm{a}^{-1}$ between 1946-1952 (Mason, 1954), then increased to $6.9 \mathrm{~m} \mathrm{a}^{-1}$ between 1954-1964 (Dodge, 1964) (Figure 36). Errors are not known. The velocity did not change through the late 1980s, as measured by Lundstrom (1992), 6.9 $\pm 1.7 \mathrm{~m} \mathrm{a}^{-1}$ from 1984-1989. Velocities have since decreased at the B-profile to $2.3 \mathrm{~m} \mathrm{a}^{-1}$ by 2004 (this thesis). Langille's (Reid, 1905) velocity measurements $90 \mathrm{~m}$ up-glacier from the terminus between 1890 and 1896 were $15 \mathrm{~m}$ $\mathrm{a}^{-1}$, compared to $1.45 \pm 0.03 \mathrm{~m} \mathrm{a}^{-1}$ in 2004 (this thesis). 
Basal sliding resulting from melt- or rainwater reaching the glacier base appears to contribute to summer velocity increases. A large rain event occurred between August $21^{\text {st }}$ and $24^{\text {th }}, 2004$ after which the largest displacement of the stakes and boulders during the summer (Figure 32). Overall, summer velocities on the whole are approximately $25 \%$ faster than average annual velocities.

Vertical velocity vectors show a noisy decreasing down-glacier trend. The variable slope of the glacier is likely the cause of this, as attempting to calculate emergence values of only a few $\mathrm{cm}$ is likely flawed. This is evident by a number of the stakes showing submergent velocity vectors when ablation zone vectors should be emerging (though error uncertainties place most of these at or near zero).

Nevertheless, they do indicate a rough pattern of decreasing down-glacier emergence values. 


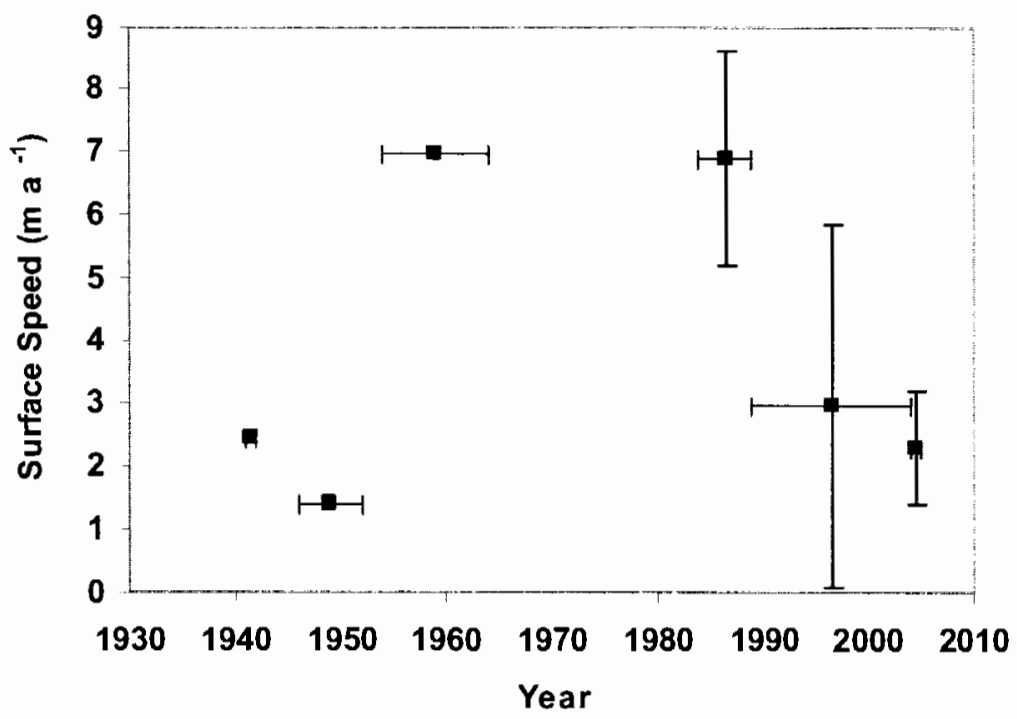

Figure 36. Surface speeds at the B-profile over time. Respective studies represent the following time spans: 1941-42 (Matthes and Phillips, 1943); 1946-52 (Mason, 1954); 1954-64 (Dodge, 1964); 1984-89 (Lundstrom, 1992); 1989-2004 (This thesis, photogrammetry); 2004-05 (This thesis, ground survey). Errors on studies prior to 1992 are unknown. 


\section{DEBRIS REPLENISHMENT MODEL}

\section{Introduction}

Debris thickness has been shown to be the major factor controlling the spatial pattern in ablation. Therefore defining the processes governing debris thickness is important. I examine debris thickness using a one-dimensional model (Lundstrom, 1993),

$$
\frac{\partial S}{\partial t}=-S \nabla v-\frac{\dot{b} C}{(1-\Phi)}+D
$$

where $S$ is the debris thickness (m), t is time (a), $v$ is velocity $\left(\mathrm{m} \mathrm{a}^{-1}\right), b^{\&}$ is the net ice mass balance $\left(\mathrm{m} \mathrm{a}^{-1}\right), C$ is the englacial volumetric concentration of debris (unitless), $\Phi$ is the porosity of supraglacial debris (unitless), and $D$ is subaerial deposition rate of debris $\left(\mathrm{m} \mathrm{a}^{-1}\right)$. The term on the left hand side is debris thickness change with time. The first term on the right side is the horizontal strain rate which affects debris thickness by ice strain, where $\nabla v$ is one-dimensional, $\partial v / \partial x$, and $\mathrm{x}$ is the downglacier coordinate. The second term is the debris flux from the glacier interior to the surface. The field measurements of debris thicknesses, surface velocities, and mass balance allow me to solve (3).

\section{Methods}

Three of the six variables $(S, v, \dot{b})$ of the equation were measured in the field. The other three variables ( $C, \Phi, D)$ are estimates from Lundstrom (1992). The englacial volumetric concentration $(C)$ was estimated by breaking a section of ice 
off of an exposed face, measuring the volume of meltwater, and then the mass of debris. From several measurements $C$ was about 0.0004 near the ELA and increased to about 0.002 near the terminus. Because my study begins $\approx 200 \mathrm{~m}$ down-glacier from the ELA, I estimated local debris concentration based on a linear interpolation of Lunstrom's two values, 0.001 at stake 12 and increasing down-glacier to 0.00195 at boulder 3, just up-glacier from the terminus. Lundstrom (1992) estimated porosity $\Phi$ to be 0.38 from 12 debris samples. Finally, Lundstrom (1992) estimated a subaerial deposition of only $6.69 \times 10^{-5} \mathrm{~m} \mathrm{a}^{-1}$ which is negligible compared to other sources and I do not include it in the analysis. Mass wasting of the moraines deposits material along the glacier margin but I focus on the debris flux along the center line profile where mass such deposition does not occur.

I first averaged each field measurement across the width of the stake array and down the glacier for a distance of about $70 \mathrm{~m}$ (the approximate thickness of the glacier) to better represent averages of debris thicknesses, ablation rates, and surface velocities for each stake segment (e.g. the area between stakes 12 and 11 is a stake segment). I then applied these averages in the model. The debris supply for the seven linear segments defined by the stake array including boulder \#3 along the glacier centerline of flow is shown in Table 12.

\section{Results}

The change in debris thickness over time $(\partial S / \partial t)$ is the sum of horizontal strain and the debris melt-out. Debris supply values range from 3.4 to $5.9 \mathrm{~mm} \mathrm{a}^{-1}$ with a mean value of $4.96 \mathrm{~mm} \mathrm{a}^{-1}$. Stake 12 provides a context for these estimates, as it 
was originally drilled on clean ice, but $\sim 1 \mathrm{~cm}$ of debris existed on the annual survey one year later. As such, a mean value of $4.96 \mathrm{~mm} \mathrm{a}^{-1}$ seems reasonable. Errors in debris thickness $(2 \mathrm{~cm})$, surface velocity (ranging $0.2-1.5 \mathrm{~cm})$, and mass balance ( 2 $\mathrm{cm})$ measurements were propagated (Baird, 1962) through (3) resulting in a nearly constant error of $2.0 \mathrm{~cm}$ for each segment of the model. Errors for englacial volumetric concentration of debris, porosity, and subaerial deposition are unknown and ignored. Horizontal strain generally increases in the down-glacier direction (Figure 37). Debris melt-out, on the other hand, linearly decreases. The sum of these two processes is a fairly linear and constant debris supply rate which averages $4.96 \pm$ $20.00 \mathrm{~mm} \mathrm{a}^{-1}$. At the uppermost stake segments, strain thickening accounts for roughly $7 \%$ of the thickening and melt-out accounts for the remaining $93 \%$. At the lowermost stake segments, strain accounts for $82 \%$ of the debris thickening and meltout contributes only $18 \%$.

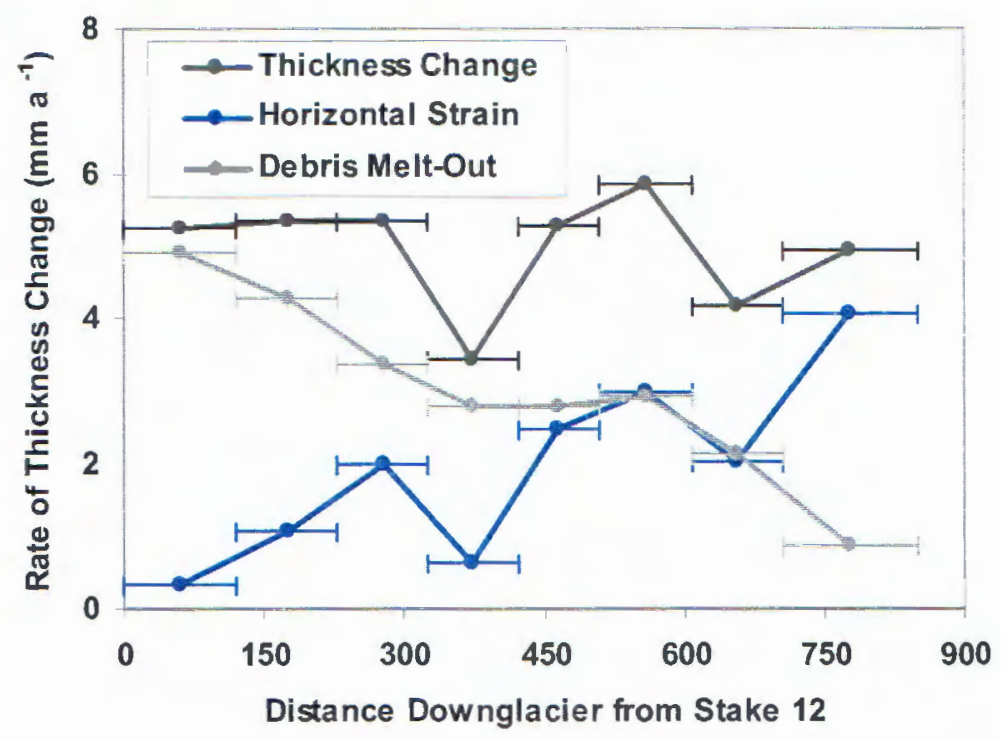

Figure 37. Debris replenishment values for each segment with the vertical strain and debris melt-out terms. Note: vertical errors are $20 \mathrm{~mm}$ for each segment. 
Table 12. Results of components in debris flux equation

\begin{tabular}{ccccc}
\hline $\begin{array}{c}\text { Stake } \\
\text { Section }\end{array}$ & $\begin{array}{c}\text { Debris Thickness } \\
(\mathbf{m})\end{array}$ & $\begin{array}{c}\text { Average Velocity } \\
\left(\mathbf{m ~ a}^{-1}\right)\end{array}$ & $\begin{array}{c}\text { Stake Segment } \\
\text { Length }(\mathbf{m})\end{array}$ & $\begin{array}{c}\text { Strain }(\mathbf{m m} \\
\left.\mathbf{a}^{-1}\right)\end{array}$ \\
\hline $12-11$ & $0.06 \pm 0.02$ & $6.81 \pm 0.02$ & 121.5 & $0.35 \pm 0.11$ \\
$11-10$ & $0.10 \pm 0.02$ & $5.89 \pm 0.01$ & 107.5 & $1.08 \pm 0.21$ \\
$10-9$ & $0.15 \pm 0.02$ & $4.70 \pm 0.01$ & 96.3 & $1.99 \pm 0.26$ \\
$9-8$ & $0.20 \pm 0.02$ & $3.93 \pm 0.02$ & 97.5 & $0.63 \pm 0.07$ \\
$8-7$ & $0.21 \pm 0.02$ & $3.26 \pm 0.02$ & 86.8 & $2.49 \pm 0.24$ \\
$7-6$ & $0.34 \pm 0.02$ & $2.31 \pm 0.01$ & 100.0 & $2.97 \pm 0.18$ \\
$6-5$ & $0.50 \pm 0.02$ & $1.67 \pm 0.01$ & 99.3 & $2.03 \pm 0.09$ \\
$5-3$ & $0.70 \pm 0.02$ & $1.05 \pm 0.00$ & 143.8 & $4.07 \pm 0.11$ \\
\hline & & & \\
& & & & \\
& Average Mass & Volumetric & Porosity & Debris Flux \\
& Balance (m a $\left.\mathbf{a}^{-1}\right)$ & (unitless) & (unitless) & \\
\hline $12-11$ & $-3.04 \pm 0.02$ & 0.001 & 0.38 & $5.25 \pm 20.00$ \\
$11-10$ & $-2.30 \pm 0.02$ & 0.00115 & 0.38 & $5.36 \pm 20.00$ \\
$10-9$ & $-1.60 \pm 0.02$ & 0.0013 & 0.38 & $5.35 \pm 20.00$ \\
$9-8$ & $-1.19 \pm 0.02$ & 0.00145 & 0.38 & $3.41 \pm 20.00$ \\
$8-7$ & $-1.08 \pm 0.02$ & 0.0016 & 0.38 & $5.27 \pm 20.00$ \\
$7-6$ & $-1.03 \pm 0.02$ & 0.00175 & 0.38 & $5.87 \pm 20.00$ \\
$6-5$ & $-0.69 \pm 0.02$ & 0.0019 & 0.38 & $4.16 \pm 20.00$ \\
$5-3$ & $-0.29 \pm 0.02$ & 0.00195 & 0.38 & $4.96 \pm 20.00$ \\
\hline
\end{tabular}

\section{Analysis}

To calculate debris thickness along the glacier centerline, I integrate equation

(3),

$$
S=\int_{0}^{L} \frac{S^{\prime}(x)}{v(x)} d x
$$

where $S$ is the debris thickness, $S^{\prime}$ is the debris flux as defined by (3), and $v$ is the glacier velocity. These terms are integrated down the glacier starting at the origin (stake 12) down length $L$ to boulder 3 , near the terminus. To solve (4), I divide the 
centerline into segments defined by the interval distance between the stakes. For example, $S^{\prime}(x)$ and $v(x)$ are defined as an average from stake 12 to stake 11 .

The resulting model reflects field measurements, though are inflated, with each following $2^{\text {nd }}$ order polynomial trends $\left(R^{2}=0.91\right.$ and 0.99 , respectively) (Figure 38 ). The model predicts $9 \mathrm{~cm}$ of debris at stake 11 , close to the $8 \mathrm{~cm}$ present. However, below stake 11, the model diverges from the field measurements. The model predicts $53 \mathrm{~cm}$ of debris at stake 7 compared to the actual $23 \mathrm{~cm}$. The lowest point, boulder 3 , has $\sim 120 \mathrm{~cm}$ of debris in reality, while the model predicts $180 \mathrm{~cm}$.

Although the model results are reasonable compared to field measurements, it is clear the model over-estimates debris thickness. Adjustments could be made by decreasing englacial concentration, increasing porosity values, or decreasing travel time (increasing velocity). We have no a priori reason to change englacial concentration or porosity. Glacier velocity, however, is known to have been higher in the recent past when the debris was accumulating. My measured velocity is only a snapshot of current conditions, not those governing the debris accumulation over the past years. An additional factor that could have increased debris thickness is the kinematic wave that traveled down-glacier between 1956 and 1982 (Chapter 5). By interpolating velocity at the B-profile between Lundstrom (1992) and my results, surface velocity was $\sim 4 \mathrm{~m} \mathrm{a}^{-1}$ at the B-profile (compared to the current $2.3 \mathrm{~m} \mathrm{a}^{-1}$ ) in 1993. Therefore, increasing stake segment velocities by just $2 \mathrm{~m} \mathrm{a}^{-1}$ from my ground survey data results in a model that much more closely predicts actual field measured debris thicknesses (Figure 38). The results of increasing glacier velocity greatly 
improve the match with measurements. The debris model explains the observed thickness fairly well although variations are apparent. Given the complexity of the morphology and debris on Eliot Glacier, I am pleased with the results from such a simple model.

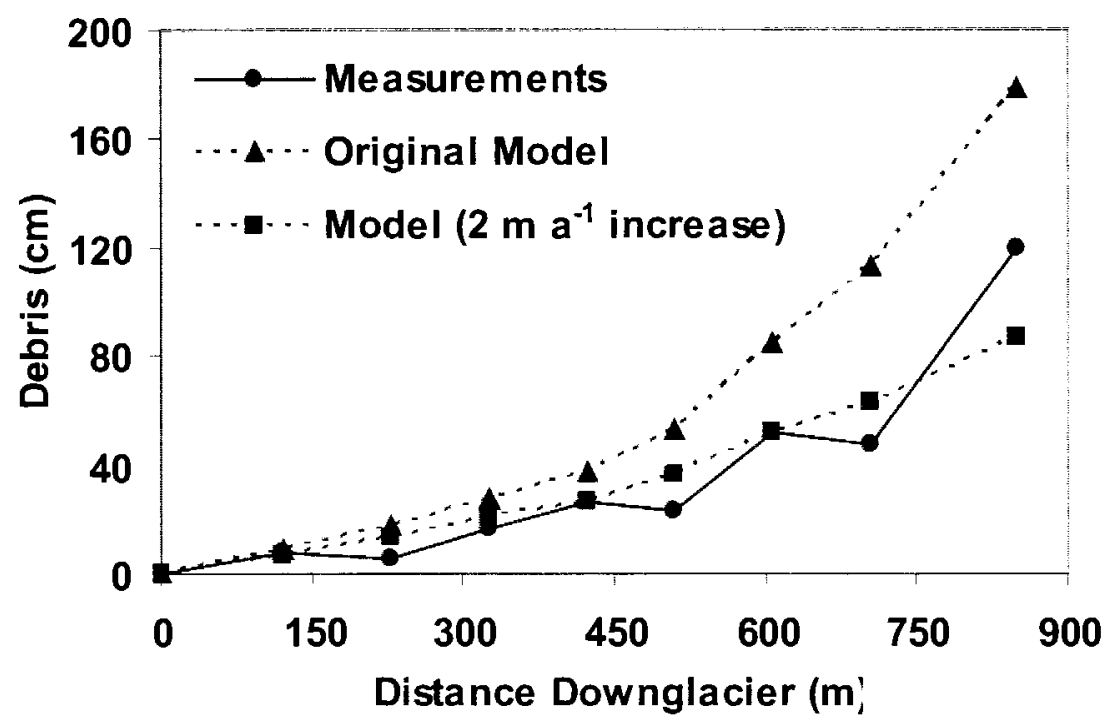

Figure 38. Field measurements of debris cover (solid line/circle) plotted with model results. Original model results are the triangle/dashed line whereas adjusted model results (increase of $2 \mathrm{~m} \mathrm{a}^{-1}$ ) are the square/dashed line. 


\section{CLIMATE AND GLACIER CHANGE}

\section{Introduction and Methods}

Ideally, I would examine the changes of Mount Hood's glaciers with a surface energy balance. However, historic data on wind and humidity are unavailable, and as such I use annual temperature and winter precipitation as indicators instead (Paterson, 1994). I do not statistically examine the relation between climate and glacier change, but rather perform a cursory graphic examination of the patterns between the two. PRISM data (4-km grid cell centered on Mount Hood's summit) obtained from Oregon Climate Service (Daly et al., 1997) is used in attempt to visually examine mean annual temperature and winter precipitation against Eliot Glacier's area and morphological changes.

\section{Results and Analysis}

Temperature and precipitation have experienced three broad trends since 1900 (Figure 39). From 1900 until about 1940, temperatures increased while precipitation was generally low. Between 1940 and the mid-1970s, temperatures were lower and precipitation (notably winter precipitation) were higher. Since the mid-1970s, temperature has ridden steadily and precipitation has decreased somewhat. Eliot Glacier's spatial and morphological changes over the past 104 years are a reflection of the shifting climate of Mount Hood. Temperatures on Mount Hood have experienced three trends during the past century. From 1900 through 1940, temperatures warmed, and then cooled until the early 1960s before warming through the present day. 
Accumulation season precipitation has mirrored these trends with a marked increase during the cool period of the middle century.
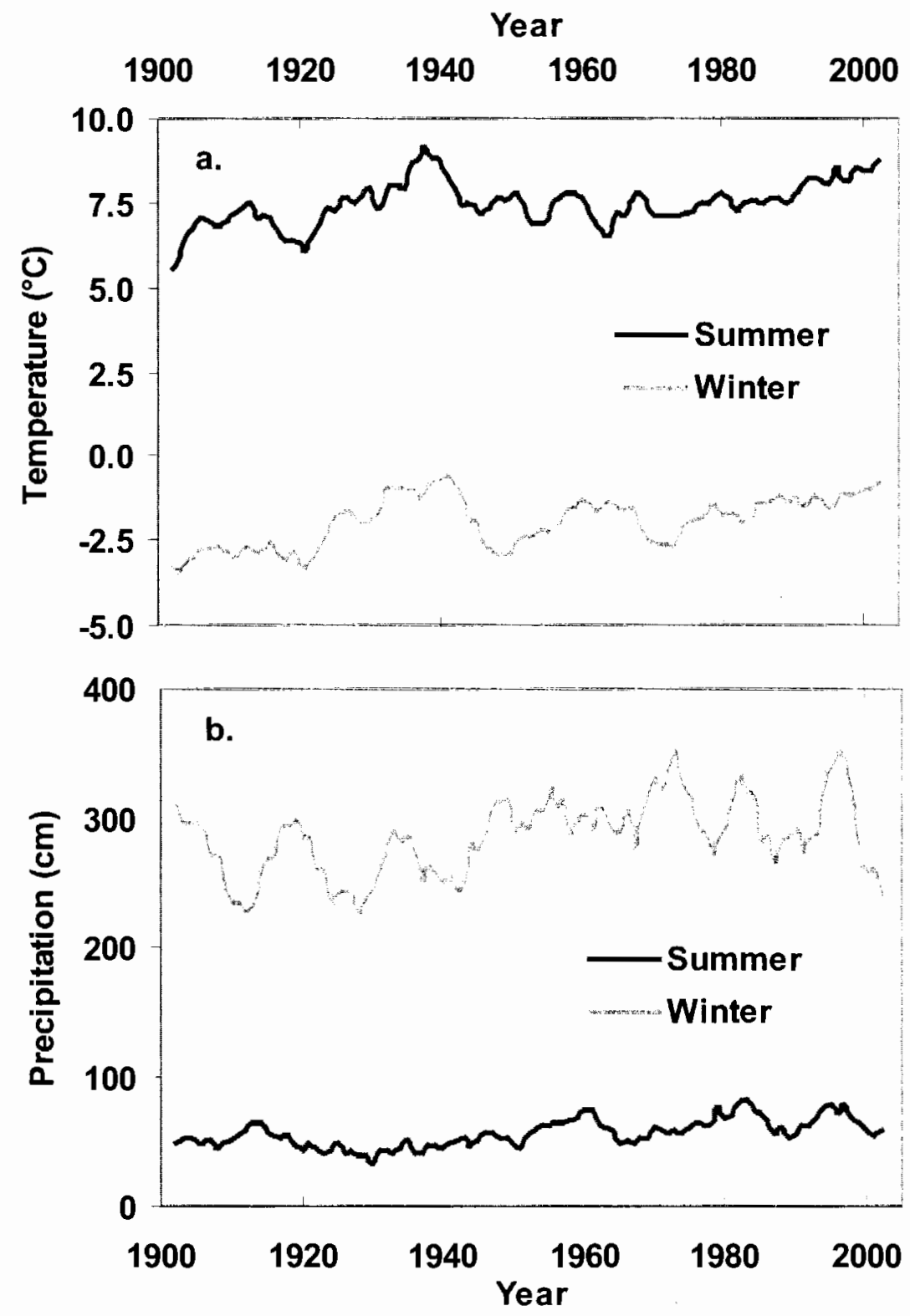

Figure 39. (a) Five-year running average temperatures and (b) five-year running average precipitation values from 1900-2004. Summer season is defined as May 1 September 30 and winter season is defined as October 1 - April 30. Source: Oregon Climate Service. 
Eliot Glacier's area has reflected changes in climate. Area decreased from 1901 until the mid 1950s in response to warming temperatures (Figure 40). It then increased until the early 1970 s in response to the mid-century decrease in temperatures and increase in accumulation season precipitation. Since the 1970s, temperatures increased and the glacier has retreated. Area changes of Eliot Glacier lag temperature/precipitation change by 10-15 years after (Figure 40), which is consistent with nearby Mount Rainier's 8-10-year lag with associated 6-36-year response time (Nylen, 2004). The response time is a dynamical response to changes in mass input (Jóhannesson et al., 1980). The statistical relationship between glacier area is significant, as a multiple linear regression of Eliot Glacier's area as a function of temperature and precipitation has an $R^{2}$ value of 0.35 ( $\mathrm{p}$-value $\left.<0.001\right)$. Additionally, applying a 10-year lag to area results in an $R^{2}$ value of 0.61 (p-value $<0.0001$ ). 

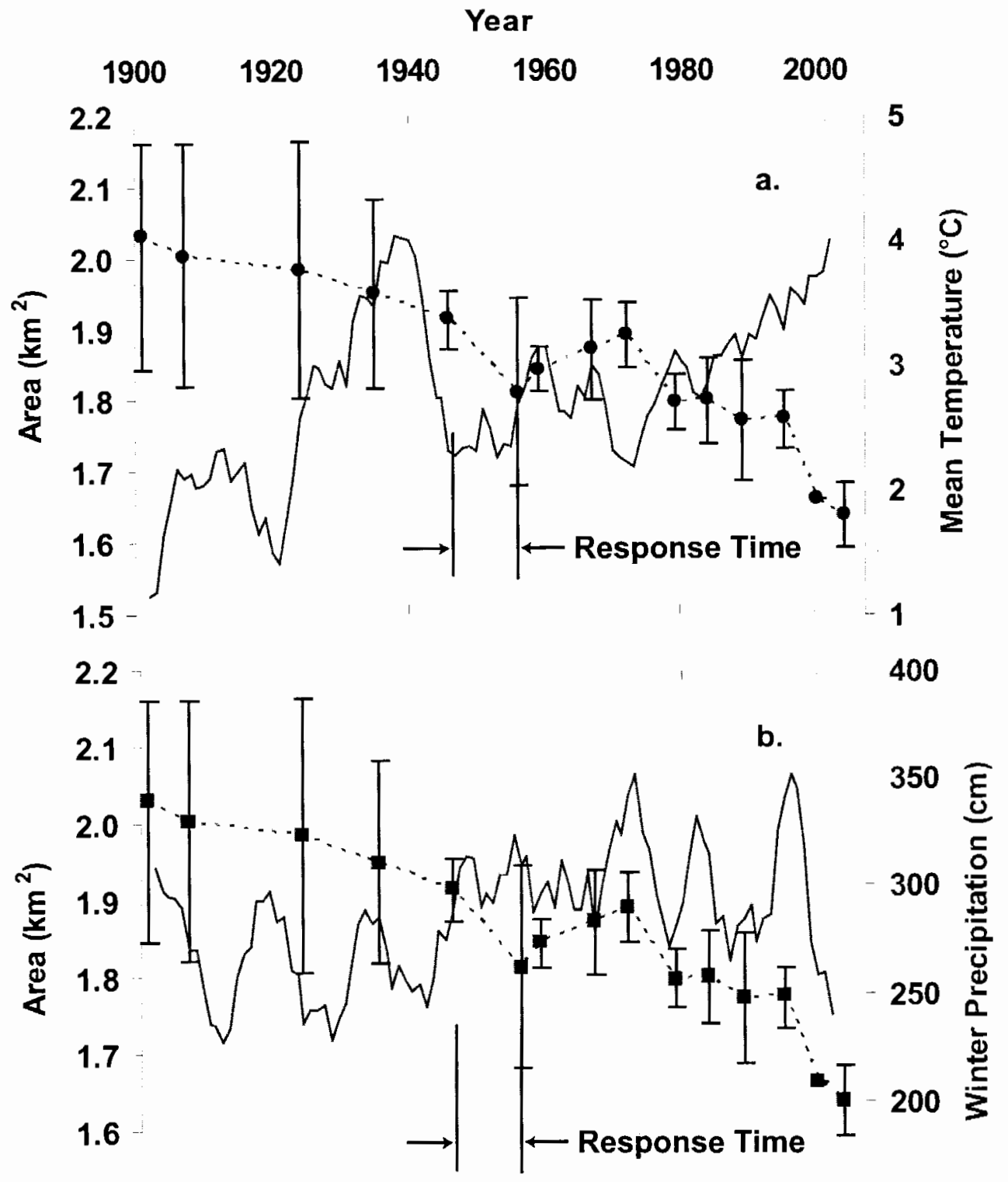

1.5 150 $\begin{array}{llllll}1900 & 1920 & 1940 & 1960 & 1980 & 2000\end{array}$ Year

Figure 40. (a) Eliot Glacier's area (dashed) over time compared to mean temperatures on Mount Hood; (b) Eliot Glacier's area (dashed) compared to winter precipitation.

Ice thickness at the B-profile also reflects trends in the climate of Mount Hood. During the first part of the century, while temperatures were warming, the glacier was 
thinning. Assuming a B-Profile glacier thickness of about $106 \mathrm{~m}$ in 1901 (based on H.F. Reid photographs) the glacier thinned in response to increasing summer and winter temperatures almost linearly until 1956 , when it thickened in response to a decrease in temperatures and an increase in snowfall $\sim 1940$ (Figure 41 ). Ice thickness at the B-profile leveled off around 1970 but then slightly thickened once again following a temporary decrease in summer and winter temperatures in the early-1970s. Temperatures have risen steadily since then and the glacier has thinned in response. Ice thickness variations at the B-Profile appear to have about a 7 to 10 -year lag time from changes in temperature or precipitation, as illustrated by Figure 41. 

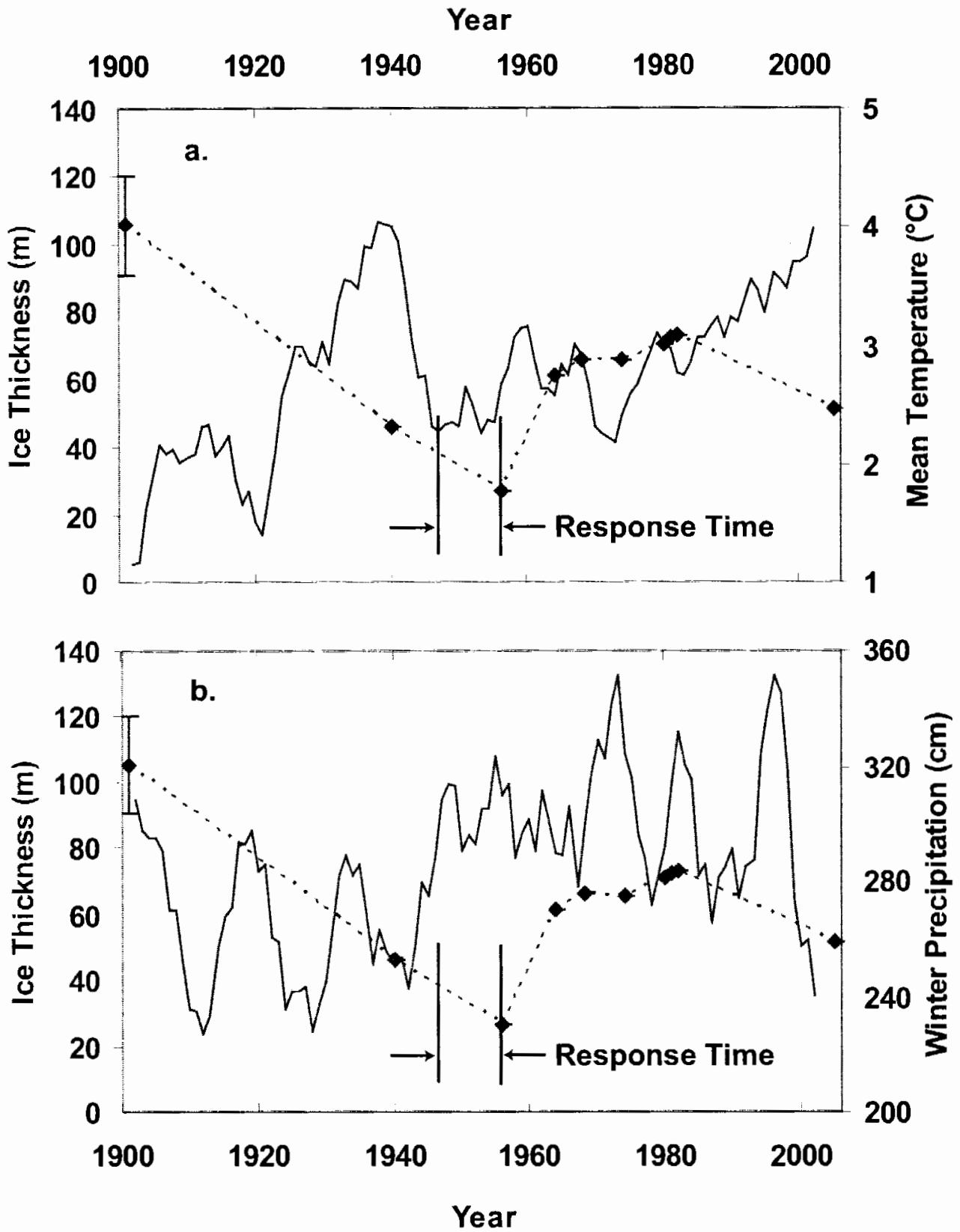

Figure 41. Ice thickness at the B-Profile (dashed line) compared to (a) temperature and (b) precipitation.

Surface velocities have coincided with ice thickness fluctuations and climate change (Figure 42). Velocities at the B-profile dropped to a low of $1.4 \mathrm{~m} \mathrm{a}^{-1}$ in 1949 in response to warming temperatures from 1900 to 1940. Velocities were high 
between 1959 and the 1980s in response to the ice thickness increases associated with cooler temperatures in the late 1960 s and early 1970 s. Since then, temperatures have risen steadily, the glacier has thinned, and velocities have decreased.

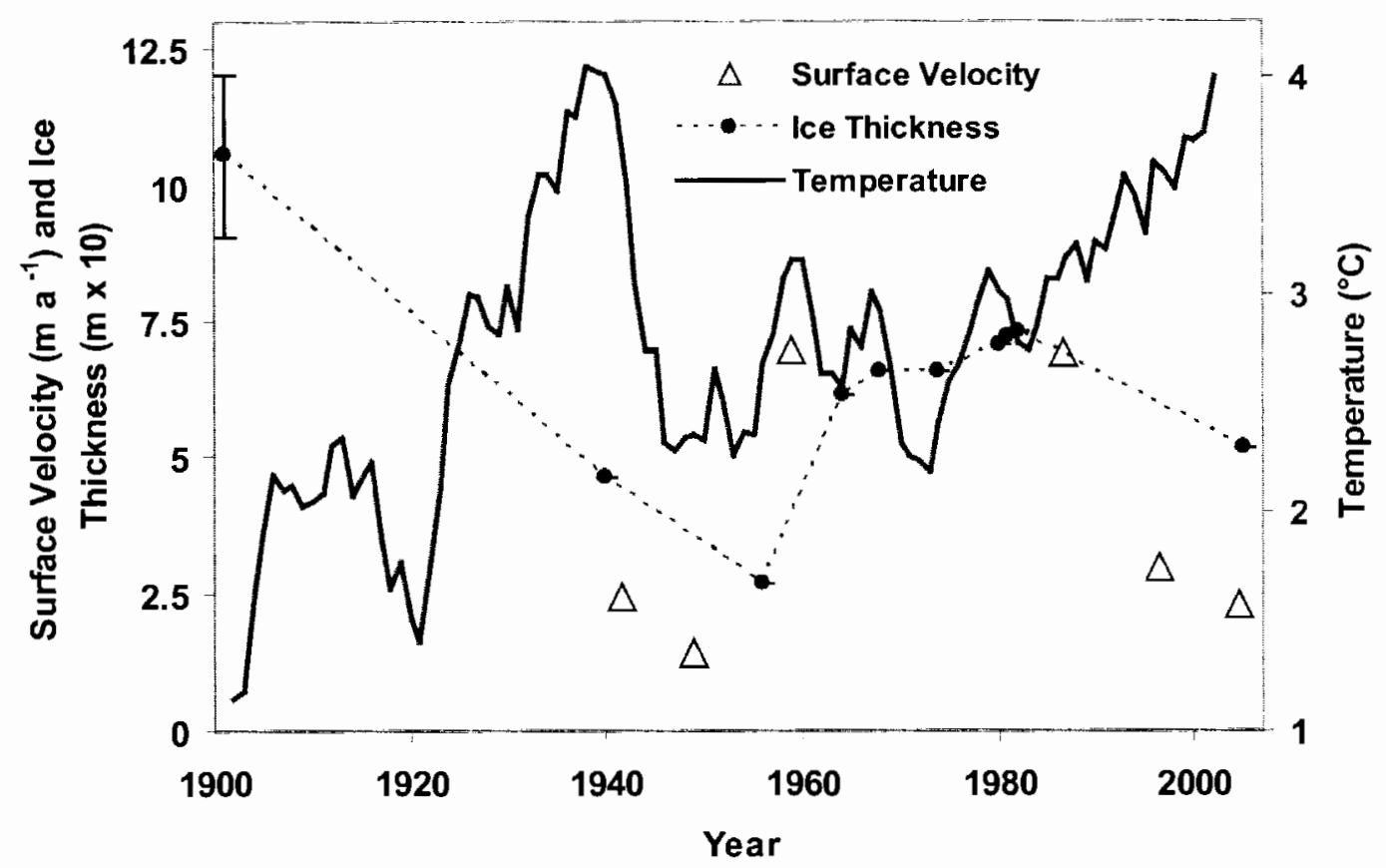

Figure 42. Ice thickness and surface velocity over time compared to 5-year running average temperature.

Coe, White River, Reid, and Sandy glaciers all experienced increases in area in the mid-1900s similar to Eliot associated with lower temperatures and increased winter precipitation, though their respective timings differ slightly (Figure 9). About $25 \%$ of White River's loss is from the upper reaches of the glacier. Consequently, the glacier head is about $400 \mathrm{~m}$ lower than it was in 1907. This upper glacier loss is probably a result of new fumaroles prior to 1937 (McNeil, 1937) and this contributed to the terminus retreat. Hague described the White River Glacier as starting in the 
crater in 1871 (King, 1871) but by 1882 a steaming fumarole was reported at this location (McNeil, 1937). Unlike Eliot, Ladd and Newton Clark glaciers are the only glaciers of the seven on Mount Hood in this study that did not increase in area as a result of the cooler temperatures and increased winter precipitation, but their rates of decline in area did slow during this period.

On Three Sisters in central Oregon, Collier Glacier's pattern of shrinkage differs from the debris-covered glaciers on Mount Hood's north side but is fairly similar to the "clean" White River Glacier. Collier increased in area between 1941 and 1949, much like White River Glacier, and then retreated again before increasing briefly around 1980. This increase is not seen with the glaciers of Mount Hood, though Eliot and Reid glaciers advanced slightly around 1990. The presence of Collier Cone (Figure 10) blocked the downvalley flow of Collier Glacier during the LIA. As a result, the glacier thickened and started to flow around the cone but did not advance appreciably. As a result, the glacier did not start retreating until after the other glaciers as a result of the thick ice. The low slope above Collier Cone and the thin ice of the glacier caused increased retreat rates, resulting in area loss (Mountain, 1984; McDonald, 1995). 


\section{DISCUSSION AND CONCLUSIONS}

The first goal of this thesis was to document the spatial change of Eliot Glacier since 1901 and place these results into the context of Mount Hood's six other glaciers as well as Collier Glacier on North Sister, Oregon. Eliot Glacier retreated until the mid-1950s, at which point it advanced until the early 1970 s before continuing to retreat through today, and has lost approximately $19 \%$ of its 1901 area. This retreat/advance/retreat pattern is essentially mirrored by the other six glaciers examined on Mount Hood. Results from this study are similar to Lillquist and Walker (2006), who found that five of Mount Hood's glaciers experienced terminus retreat ranging from $62 \mathrm{~m}$ at Newton Clark Glacier to $1102 \mathrm{~m}$ at Ladd Glacier. However, variations in our results do exist, as my study is a more detailed examination of area change of Mount Hood's glaciers.

All but two of Mount Hood's glaciers (Newton Clark and Ladd) followed a retreat/advance/retreat pattern. Collier Glacier's areal chronology varies from this pattern because of its unique topographic influences as a result of Collier Cone that altered its retreat pattern (Mountain, 1984; McDonald, 1995). Elsewhere in the Pacific Northwest, Mount Rainier's glaciers followed the retreat/advance/retreat pattern similar to Mount Hood's glaciers, retreating until the late 1950s, advancing through the early 1980s, and retreating again through the mid-1990s (Nylen, 2004). The advance of Mount Rainier's largest glaciers lasted about a decade longer than the advance of Mount Hood's. This is possibly a result of the larger size of Mount Rainier's glaciers and the longer response time for the larger glaciers to begin 
retreating. Between 1910 and 1994, the total glacier area loss on Mount Rainier was $18.5 \%$ (Nylen, 2004). Between the first decade of the twentieth century and 2004, the seven Mount Hood glaciers in this study lost $32.7 \%$, almost double the loss on Mount Rainier.

Generally speaking, losses of Eliot Glacier and on Mount Hood reflect magnitudes observed for glaciers elsewhere in the United States and the rest of the world. However, detailed differences in rates and magnitudes do exist. For example, the area loss in the North Cascades, Washington, was 7\% between 1958 and 1998 (Granshaw and Fountain, 2006), while glaciers in the Sierra Nevada have lost an average of $50 \%$ during the last century (Basagic and Fountain, 2005). In Glacier National Park, glaciers lost an astounding 65\% between 1850 and 1979 (Hall and Fagre, 2003), whereas glacier retreat in the Wind River Range, Wyoming, (Marston et al., 1991) and the Colorado Front Range (Hoffman and Fountain, 2006) are similar in magnitude to those on Mount Hood.

Most of the glaciers around the world have retreated over the past $100+$ years, many of them following the retreat/advance/retreat pattern observed on Mount Hood (Haeberli et al., 1998). The glaciers of the contiguous United States retreated until 1950 (Meier and Post, 1962) before advancing and then retreating again starting at varying times between the 1970s and early 1990s (Dyurgerov and Meier, 1997). The glaciers of the European Alps and Caucasus have lost about a third of their area (Meier et al., 2003), which is similar to Mount Hood. Other regions have not seen the mid- 
century advance, but rather steadily retreated, notably in the tropics of Africa (Kaser et al., 2004).

The second goal of this thesis was to examine the effect the debris cover has had on the retreat rate of Eliot Glacier as opposed to the rest of Mount Hood's glaciers. Two debris-covered glaciers in Washington that have been examined and are comparable in size to the glaciers of Mount Hood's north side are the Mazama Glacier, Mount Baker, (Pelto, 2000) and the Carbon Glacier, Mount Rainier (Nylen, 2004). The Mazama Glacier has retreated the least from its LIA extent of all the glaciers on Mount Baker, which is attributable to its debris-covered terminus. The debris-covered Carbon Glacier on Mount Rainier retreated $~ 50 \%$ less than the other glaciers on Mount Rainier (Nylen, 2004) and was the last glacier to begin receding following a mountain-wide glacial advance into the 1980s. Similarly, Eliot and Coe glaciers were the last glaciers on Hood to begin to recede in the 1970s on Mount Hood, indicative of the influence of debris cover on glacier response to climate change.

My debris thickness measurements show increasing thickness down-glacier and laterally toward the glacier margins, ranging from 0 to $\sim 1.5 \mathrm{~m}$. Eliot Glacier's debris cover is higher than some debris-covered glaciers in the Pacific Northwest, which may have thicknesses as low as $0.25 \mathrm{~m}$ (Pelto, 2000) to $0.5 \mathrm{~m}$ (Mattson, 2000), and less than Galena Creek Rock Glacier $(3+\mathrm{m})$ in Wyoming (Konrad et al., 1999). This debris cover is the main factor in determining ablation rates. Ablation rates on Eliot Glacier's debris-covered terminus appear to have increased slightly in response 
to warmer temperatures, with areas of higher debris thicknesses increasing less than thin debris covers. Iwata et al. (2000) demonstrated that ablation rates on areas of Khumbu Glacier with the thickest debris did not change between 1978 and 1995. Where ice cliffs, clean of debris, are present on Eliot, ablation was much greater, similar to that observed by Sakai et al. (2000) and Benn et al. (2000). Moreover, Eliot Glacier's thinning rate from 1982 to 2005 of $1.0 \mathrm{~m} \mathrm{a}^{-1}$ is higher than the thinning rate of Khumbu Glacier between 1978 and 1995 of about $0.6 \mathrm{~m} \mathrm{a}^{-1}$ (Kadota et al., 2000). It is unclear if the recent climate warming in the Himalayas has been less than that at Mount Hood or if local climatic variations are causing a higher thinning rate on Eliot Glacier. Additionally, differences in debris thickness between the glaciers may exist. Like Eliot Glacier's debris-covered terminus, Galena Creek Rock Glacier`s mass balance is also the opposite of "clean" glaciers, with its upper two-thirds having a negative mass balance (Konrad et al., 1999). The upper two-thirds of "clean" glaciers typically have positive mass balances with this section being the accumulation area of the glacier. Eliot Glacier has a typical accumulation-area ratio (AAR) of $<0.6$, comparable to "clean" glaciers, rather than rock glaciers such as Galena Creek, which have AARs of 0.1 (Konrad et al., 1999). The spatial pattern of Eliot Glacier's mass balance exhibits a "clean" glacier trend from its uppermost reach down until the start of the debris cover (Dodge, 1987), at which point it transitions to a rock glacier trend, with the mass balance increasing from about $-4 \mathrm{~m} \mathrm{a}^{-1}$ to almost $0 \mathrm{~m} \mathrm{a}^{-1}$ near the terminus. 
Ice thicknesses at the B-Profile in the debris-covered area of the glacier decreased from $\sim 100 \mathrm{~m}$ in 1901 to $\sim 25 \mathrm{~m}$ in 1956 , after which a kinematic wave traveled through in the late 1950s/early 1960s, that increased ice thickness to $\sim 73 \mathrm{~m}$ in 1982. Since the early-1980s, the profile thinned at $\sim 1.0 \mathrm{~m} \mathrm{a}^{-1}$ and currently (2005) is $\sim 52 \mathrm{~m}$ thick. A lag time of about seven to ten years exists between positive shifts in mass input to the glacier and thickness increases at the B-Profile. Surface velocities currently vary from about $7.8 \mathrm{~m} \mathrm{a}^{-1}$ at the upper extent of the study area to zero below the active terminus (located on an area of stagnant debris-covered ice). Velocities at the B-Profile have reflected the changes in ice thickness, decreasing from $2.4 \mathrm{~m} \mathrm{a}^{-1}$ in the early $1940 \mathrm{~s}$ (Matthes and Phillips, 1943) to $1.4 \mathrm{~m} \mathrm{a}^{-1}$ in the late $1940 \mathrm{~s}$, then increased to $6.9 \mathrm{~m} \mathrm{a}^{-1}$ in the late 1950s and early 1960s (Dodge, 1964). Lundstrom (1992) measured velocities at $6.9 \pm 1.7 \mathrm{~m} \mathrm{a}^{-1}$ in the late $1980 \mathrm{~s}$ and currently they are about $2.3 \mathrm{~m} \mathrm{a}^{-1}$.

The conceptual framework of my study incorporates my debris thickness, ablation, and surface velocity measurements to estimate debris replenishment to the glacier surface over time. I hypothesize that the thickening debris cover $\left(\sim 0.5 \mathrm{~mm} \mathrm{a}^{-1}\right)$ of Eliot (and Coe) Glacier is an important factor in buffering the glacier mass balance response to climate warming. Because of the insulating effects of the debris cover Eliot Glacier is more sensitive to changes in mass input to the glacier rather than to changes in mass loss through melting. That the current surface elevation of the Bprofile is only now at the elevation of the pre-wave elevation in 1940 points to the reduced effect of ablation caused by the presence of the thickening debris cover. 
However, because the glacier continues to thin, it is likely the rate of debris thickening is not keeping pace with the rate of climate warming.

Finally, because Eliot and Coe glaciers have lost less than $20 \%$ of their 1901 and 1907 areas, respectively, while Mount Hood as a whole has lost $34 \%$ of its glacier cover, it would be easy to deduce that they have not lost as much mass. However, on glaciers such as Eliot and Coe, which are confined to deep, long, and narrow valleys, area loss is not the key indicator of change, but rather volume loss (thinning) is, as the repeat photographs demonstrate. Additionally, while the relatively small shrinkage of Eliot and Coe glaciers compared to other glaciers on Mount Hood appears related to the thickening of the debris layer, other mitigating factors exist. Both Eliot and Coe have the highest accumulation zones which head near the peak of Mount Hood (3425 m). Therefore, rising freezing levels and snow lines have not affected these glaciers as much as the other glaciers, which have a smaller elevation range. Aspect is likely another factor, as Eliot and Coe are the most northerly-flowing glaciers on the mountain and as such are larger and would not respond to changes in climate as quickly as smaller glaciers elsewhere on the mountain. These factors have also been documented on Mount Rainier (Nylen, 2004).

\section{Future Implications}

Eliot Glacier's rate of recession between 1901 and 2004 has been about $6.25 \mathrm{~m}$ $\mathrm{a}^{-1}$. If this rate of retreat were to continue, it would take at least 600 years for the glacier to disappear. Using the retreat rate between 1989 and 2004, $20 \mathrm{~m} \mathrm{a}^{-1}$, Eliot Glacier would disappear in at least 180 years. These values are minima because 
glacier recession tends to slow as the glaciers retreat into higher, more glaciallyprotected environments where non-climatic effects become important (e.g. avalanching and wall-shading). This has implications for the alpine ecology of Mount Hood. The shrinking or loss of glaciers affects downstream ecosystems dependent upon glacial meltwater during dry summer months. I estimate the glaciers of Mount Hood produce approximately $15.4 \times 10^{6} \mathrm{~m}^{3}$ of meltwater each year, and if this declines, people in the Hood, White, and Sandy River valleys will need to look elsewhere during summer months to supply water to the agricultural enterprises dependent on the glacial meltwater.

\section{Suggestions for Future Research}

Rain and supraglacial streams are responsible for the removal of debris from the glacier surface and increases in glacial ablation. The debris replenishment model did not account for these losses. However, a number of rain events visibly altered the debris cover and play an important role in debris cover dynamics. A study of the supraglacial transport and removal of debris would be beneficial.

Mass balance measurements should be extended up-glacier to the clean ice which most likely experienced a reduction in mass balance and that reduction is being reflected in the down-glacier debris-covered zone with the current thinning seen at the B-Profile. Additionally, areas where supraglacial streams cross should be studied for ablation rates, notably small debris-free faces. It is likely that localized ablation in these areas is extremely high and should be included in ablation analyses in the future. As the glacier continues to thin, new areas of bedrock are being exposed, which is 
altering the flow pattern of the glacier. A more robust network of stakes covering these areas would be valuable. It appears that ice flow to the far western side of the glacier has been severely reduced and it is likely that ice velocities below the recentlyemerged bedrock ridge is much slower than the ice in the center of the glacier. 


\section{0, REFERENCES CITED}

Babson, S.G. 1997. Letters from Arnold Hague: early Mount Hood explorer, editor. Oregon Historical Quarterly, Summer, 1997, p. 206-221.

Baird, D.C. 1962. Experimentation: an introduction to measurement theory and experimental design. Englewood, New Jersey, Prentice-Hall, 195 p.

Basagic, H.J. and Fountain, A.G. 2005. Measuring twentieth century surface area changes at seven glaciers in the Sierra Nevada, California. Geological Society of America Abstracts with Programs, 37(7):332.

Benn, D.I., Wiseman, S., and Warren, C.R. 2000. Rapid growth of a supraglacial lake, Ngozumpa Glacier, Khumbu Himal, Nepal. In: Debris-Covered Glaciers, IAHS Publication no. 264:177-185.

Coleman, E.T. 1877. Mountains and Mountaineering in the Far West. The Alpine Journal, 8:233-242.

Crandell, D.R. 1980. Recent eruptive history of Mount Hood, Oregon, and potential hazards from future eruptions. U.S. Geological Survey Bulletin 1492, $81 \mathrm{p}$.

Daly, C., Taylor, G. and Gibson, W. 1997. The PRISM approach to mapping precipitation and temperature. I0th Conf. on Applied Climatology, Reno, NV, American Meteorological Society, p. 10-12.

Dart, J.O. and Johnson, D.M. 1981. Oregon: Wet, high, and dry. Portland, Oregon: The Hapi Press, 365 p.

Dethier, D.P. 1980. Reconnaissance study of Holocene glacier fluctuations in the Three Sisters area, Oregon. EOS Transactions, American Geophysical Union $61: 69$.

Dodge, N.A. 1964. Recent measurements on the Eliot Glacier. Mazama, 46(13):47-49.

Dodge, N.A. 1971. The Eliot Glacier: new methods and some interpretations. Mazama, 53(13):25-29

Dodge, N.A. 1987. Eliot Glacier: net mass balance. Mazama, 69(13):52-55.

Dodge, N.A. Unpublished field notes recovered from Mazamas archives, Portland, OR. http://www.mazamas.org 
Driedger, C. and Kennard, P. 1986. Ice volumes on Cascade Volcanoes-Mount Rainier, Mout Hood, Three Sisters, and Mount Shasta. U.S. Geological Survey Professional Paper 1386, 28 p.

Dyurgerov, M.B. and Meier, M.F. 1997. Mass balance of mountain and subpolar glaciers: a new global assessment for 1961-1990. Arctic and Alpine Research, 29:379-391.

Fleming, S.W. and Clarke, G.K.C. 2003. Glacial control of water resource and related environmental responses to climatic warming: empirical analysis using historical streamflow data from Northwestern Canada. Canadian Water Resources Journal, 28(1):69-86.

Fountain, A.G. and Tangborn, W.V. 1985. Effects of glaciers on streamflow variations. Water Resources Research, 21(4):579-586.

Fountain, A.G. and Jacobel, R.W. 1997. Advances in ice radar studies of a temperate alpine glacier, South Cascade Glacier, Washington, U.S.A. Journal of Glaciology, 24:303-308.

Fushimi, H., Ikegami, K., Higuchi, K., and Shankar, K. 1985. Nepal case study: Catastrophic floods. In: Techniques for prediction of runoff from glacierized areas, IAHS Publication no. 149:125-130.

Gades, A., Conway, H., Nereson, N., Naito, N., and Kadota, T. 2000. Radio-echo sounding through supraglacial debris on Lirung and Khumbu Glaciers, Nepal Himalayas. In: Debris-Covered Glaciers, IAHS Publication no. 264:13-22.

Gilardi, A.J. 1935. Unpublished photograph in Mazamas archives, Portland, Oregon. Reference \# p16.

Granshaw, F.D. and Fountain, A.G. 2006. Glacier change (1958-1998) in the North Cascades National Park Complex. Washington, USA. Journal of Glaciology, 52, 177, 251-256.

Haeberli, W., Hoelzle, M., and Suter, S. 1998. Into the second century of worldwide glacier monitoring - prospects and strategies. Studies and Reports in Hydrology. Paris: UNESCO, p. 227.

Hall, M.P. and Fagre, D.B. 2003. Modeled climate-induced glacier change in Glacier National Park, 1850-2100. Bioscience, 53(2):131-140.

Handewith, H. 1959. Recent glacier variations on Mt. Hood. Mazama, 40(14):23-28. 
Hoffman, M.J., Fountain, A.G., and Achuff, J.M. 2006, accepted. Twentiethcentury variations in area of cirque glaciers and glacierets, Rocky Mountain National Park, Rocky Mountains, Colorado, USA, Annals of Glaciology.

Humlum, O. 1999. The climatic significance of rock glaciers. Permafrost and Periglacial Processes, 9(4):375-395.

Iwata, S., Tatsuto, A., Tsutomu, K., Katsumoto, S., and Satoru, Y. 2000. Morphological evolution of the debris cover on Khumbu Glacier, Nepal, between 1978 and 1995. In: Debris-Covered Glaciers, IAHS Publication no. 264:3-11.

Jóhannesson, T., Raymond, C.F., and Waddingon, E.D. 1980. A simple method for determining the response time of glaciers. In: Oerlemans, J., ed., Glacier fluctuations and climate change: Dordecht, Netherlands, Kluwer Academy Publishing, p. 343-352.

Kadota, T., Seko, K., Aoki, T., Iwata, S., and Yamaguchi, S. 2000. Shrinkage of the Khumbu Glacier, east Nepal from 1978 to 1995. In: Debris-Covered Glaciers, IAHS Publication no. 264:235-243.

Kaser, G., Hardy, D.R., Mölg, T., Bradley, R.S., and Hyera, T.M. 2004. Modern glacier retreat on Kilimanjaro as evidence of climate change: observations and facts. International Journal of Climatology, 24:329-339.

Kayastha, R.B., Takeuchi, Y., Nakawo, M., and Ageta, Y. 2000. Practical prediction of ice melting beneath various thickness of debris cover on Khumbu Glacier, Nepal, using a positive degree-day factor. In: Debris-Covered Glaciers, IAHS Publication no. 264:71-81.

King, C. , 1871. Active Glaciers within the United States. Atlantic Monthly, 27:8 March 371-377.

Kiver, E.P. 1974. Holocene glaciation in the Wallowa Mountains, Oregon. In: Mahaney, W.C. (ed.) Quaternary Environments Proceedings of a Symposium: Geographical Monographs No. 5, York University, Toronto, Canada.

Konrad, S.K., Humphrey, N.F., Steig, E.J., Clark, D.H., Potter, N., and Pfeffer, W.T. 1999. Rock glacier dynamics and paleoclimatic implications. Geology, 27(12):1131-1134.

Konrad, S.K. and Humphrey, N.F. 2000. Steady-state flow model of debris-covered glaciers (rock glaciers). In: Debris-Covered Glaciers, IAHS Publication no. 264:255-263. 
Lafrenz, M.D. 2001. The neoglacial history of Mt. Thielsen, Southern Oregon Cascades. M.S. Thesis, Portland State University, Portland, Oregon, 80 p.

Lawrence, D.B. 1948. Mt. Hood's eruptions and glacier advances. Mazama, $30(13): 22-29$.

Licciardi, J.M., Clark, P.U., Brook, E.J., Elmore, D., and Sharma, P. 2004. Variable responses of western U.S. glaciers during the last deglaciation. Geological Society of America, 32:81-84.

Lillquist, K.D. 1989. Holocene Fluctuations of the Coe Glacier, Mt. Hood, Oregon. M.S. Thesis, Portland State University, Portland, Oregon.

Lillquist, K.D. and Walker, K.W. 2006. Historical glacier and climate fluctuations at Mount Hood, Oregon. Arctic, Antarctic, and Alpine Research. 38(3):399-412, 128 p.

Lundstrom, S.C. 1992. The budget and effect of superglacial debris on Eliot Glacier, Mt. Hood, Oregon. Ph.D. dissertation, University of Colorado, Boulder, Colorado, $183 \mathrm{p}$.

Lundstrom, S.C., McCafferty, A.E., and Coe, J.A. 1993. Photogrammetric analysis of 1984-1989 surface altitude change of the partially debris-covered Eliot Glacier, Mt. Hood, Oregon, U.S.A. Annals of Glaciology, 17:167-170.

Marcott, S. 2005. A tale of Three Sisters: Reconstructing the Holocene glacial history and paleoclimate record at Three Sisters Volcanoes, Oregon, United States. M.S. Thesis, Portland State University, Portland, Oregon, 93 p.

Marshall, E.A., Stadter, F.W., Lee, J.A., Williams, I.A., Glisan, R.L., Conway, R., and Philpoe, E. 1925. First annual report of the research committee. Mazama, 7(2):6772.

Marston, R.A.. Pochop L.O., Kerr, G,L., Varuska, M,L., and Veryzer, D.I. 1991. Recent glacier changes in the Wind River Range, Wyoming. Physical Geography, $12(2), 115-123$.

Mason, R.S. 1954. Recent survey of Coe and Eliot Glaciers. Mazama, 36(13):37-39.

Matthes, F.E. and Phillips, K.N. 1943. Surface ablation and movement of the ice on Eliot Glacier. Mazama, 25(12):17-23. 
Mattson, L.E. 2000. Debris cover and mid-summer discharge of Dome Glacier, Canadian Rocky Mountains. In: Debris-Covered Glaciers, IAHS Publication no. 264:25-33.

Mayo, L.R., Trabant, D.C., and March, R.S. 2004. A 30-year record of surface mass balance (1966-95) and motion and surface altitude (1975-95) at Wolverine Glacier, Alaska. U.S. Geological Survey Open-File Report 2004-1069, 114 p.

McDonald, G.D. 1995. Changes in mass of Collier Glacier, Oregon, 1910-1994. M.S. thesis, Oregon State University, Corvallis, OR, $215 \mathrm{p}$.

Meier, M.F. 1962. The kinematic wave on Nisqually Glacier, Washington. Journal of Geophysical Research, 67(2):886.

Meier, M.F. 1984. Contribution of small glaciers to global sea level. Science, 226:1418-1421.

Meier, M.F., Dyurgerov, M.B., and McCabe, G.J. 2003. The health of glaciers: Recent changes in glacier regime. Climate Change, 59:123-135.

Meier, M.F. and Post, A.S. 1962. Recent variations in mass net budgets of glaciers in western North America. Symposium of Obergurgl, 63-77.

Milstein, M. "Mount Hood meltdown." The Oregonian, 26 March, 2006, pp. Al \& Al2.

Mountain, K.R. 1984. Collier Glacier: A rethink of its history and comments on its climatic status since 1975. Mazama, 66(13):34-36.

Nakawo, M., Raymond, C.F., and Fountain, A.G., eds. 2000. Debris-Covered Glaciers, IAHS Publication no. 264, 288 p.

Nakawo, M. and Young, G.J. 1981. Field experiments to determine the effect of a debris layer on ablation of glacier ice. Annals of Glaciology, 2:85-91.

Narod, B.B. and Clarke, G.K.C. 1994. Miniature high-power impulse transmitter for radio-echo sounding. Journal of Glaciology, 40(134):190-194.

Nylen, T.N. 2004. Spatial and Temporal Variations of Glaciers on Mount Rainier between 1913 and 1994. M.S. Thesis, Portland State University, Portland, OR, 114 p. 
O'Connor, J.E., Hardison, J.H., and Costa, J.E. 2001. Debris Flows from Failures of Neoglacial-Age Moraine Dams in the Three Sisters and Mount Jefferson Wilderness Areas, Oregon. U.S. Geological Survey Professional Paper 1606, 93 p.

Oregon Climate Service. 2005. Spatial Climate Analysis Service. http://www.ocs.orst.edu/prism/. Last accessed 24-Oct-05.

Oregon Geospatial Data Clearinghouse, 2006. DLCD (Department of Land Conservation and Development), 1:100,000 Zoning shapefile. http://www.oregon.gov/DAS/IRMD/GEO/alphalist.shtml. Last accessed 16-Jun06.

Ostrem, G. 1959. Ice melting under a thin layer of moraine, and the existence of ice cores in moraine ridges. Gengrafiska Annular, 41(4):228-230.

Outcalt, S.I. and Benedict, J.B. 1965. Photo-interpretation of two types of rock glacier in the Colorado Front Range. Journal of Glaciology, 5:849-856.

Paterson, W.S.B. 1994. The Physics of Glaciers. Oxford, United Kingdom: Pergamon Press, $481 \mathrm{p}$.

Paul, F. 2002. Changes in glacier area of Tyrol, Austria, between 1969 and 1992 derived from Landsat 5 Thematic Mapper and Austrian Glacier Inventory data, International Journal of Remote Sensing, 23:787-799.

Pelto, M.S. 2000. Mass balance of adjacent debris-covered and clean glacier ice in the North Cascades, Washington. In: Debris-Covered Glaciers, IAHS Publication no. 264:35-42.

Phillips, K.N. 1935. Recent changes in Hood's glaciers. Mazama, 17(12):45-50.

Phillips, K.N. 1938. Our vanishing glaciers. Mazama, 20(12):24-41.

Phillips, K.N. 1942. Terminal speeds of some Cascade Mountain glaciers. Mazama, 24(12):35-38.

Potter, N., Jr.. 1972. Ice-cored rock glacier, Galena Creek, northern Absaroka Mountains, Wyoming. Geological Society of America Bulletin, 83:3025-3058.

Porter, S.C., Pierce, K.L., and Hamilton, T.D. 1983. Late Wisconsan mountain glaciation in the Western United States, in Porter, S.C., ed., Late-Quaternary Environments of the United States, Volume I: Minneapolis, University of Minnesota Press, p. 71-111. 
Reid, H.F. 1901. Unpublished photograph in Mazamas archives, Portland, Oregon. Reference \# p17.

Reid, H.F. 1905. The glaciers of Mt. Hood and Mt. Adams. Mazama, 2(4):195-200.

Reynolds, J.M. 1999. Glacial hazard assessment at Tsho Rolpa, Rolwaling, Central Nepal. $Q J E N G$ GEOL, 32(3):209-214.

Richardson, D. 1968. Glacier outburst floods in the Pacific Northwest. Geological Survey Res. 1968, Professional Paper 600-D, D79-D86.

Richardson, S.D. and Reynolds, J.M. 2000. Degradation of ice-cored moraine dams: implications for hazard development. In: Debris-Covered Glaciers. IAHS Publication no. 264:187-197.

Sakai, A., Takeuchi, N., Fujita, K., and Nakawo, M. 2000. Role of supraglacial ponds in the ablation process of a debris-covered glacier in the Nepal Himalayas. In: Debris-Covered Glaciers, IAHS Publication no. 264:119-130.

Schlichting, R. 2001. The effect of supra-glacial debris on the melting of ice on Eliot Glacier, Mt. Hood, Oregon. Report to Mazamas, 8 p.

Scott, W.E., 1977. Quaternary Glaciation and Volcanism, Metolius River area, Oregon. Geological Society of America Bulletin, 88:113-124.

Service, R. 2004. As the west goes dry. Science, 303(5661):1124-1127.

Sherrod, D.R., and Smith, J.G. 1990. Quaternary extrusion rates of the Cascade Range, Northwestern United States and Southern British Columbia. Journal of Geophysical Research, 95(b12):19,465-19,474.

Sloan, V.F. and Dyke, L.D. 1998. Decadal and millennial velocities of rock glaciers, Selwyn Mountains, Canada. Geografiska Annaler, 80A:277-286.

Small, R.J. 1987. Englacial and supraglacial sediment: transport and deposition. In: Gurnell, A.M. and Clark, M.J. eds. Glacio-fluvial sediment transfer; an alpine perspective. Chichester, John Wiley and Sons, p. 111-145.

Wise, W.S. 1968. Geology of the Mount Hood Volcano-Andesite Conference Guidebook. International Mantle Project, Science Report 16-S and Oregon Dept. of Geology and Mineral Industries Bulletin, 62:81-98. 


\section{APPENDICES}

Appendix A. Glacier areas with root mean square errors (RMSE) for georeferenced aerial photographs and associated areal errors. Source key: USFS-United States Forest Service; USGS-United States Geological Survey; OGS-Oregon Geospatial Data Clearinghouse.

\begin{tabular}{|c|c|c|c|c|c|c|}
\hline Glacier & Year & Source & $\begin{array}{c}\text { Area } \\
\left(\mathrm{km}^{2}\right)\end{array}$ & RMSE (m) & $\begin{array}{c}\text { Inward } \\
\text { Error } \\
\left(\mathrm{km}^{2}\right) \\
\end{array}$ & $\begin{array}{r}\text { Outward } \\
\text { Error } \\
\left(\mathrm{km}^{2}\right) \\
\end{array}$ \\
\hline Coe & 1907 & USGS & 1.41 & - & -0.16 & 0.10 \\
\hline $\mathrm{Coe}$ & 1924 & USGS & 1.38 & - & -0.16 & 0.12 \\
\hline Coe & 1946 & USFS & 1.25 & 3.47 & -0.03 & 0.03 \\
\hline Coe & 1959 & USFS & 1.20 & 5.13 & -0.04 & 0.04 \\
\hline $\mathrm{Coe}$ & 1972 & USFS & 1.25 & 4.78 & -0.03 & 0.03 \\
\hline Coe & 1984 & USFS & 1.25 & 5.97 & -0.04 & 0.04 \\
\hline Coe & 2000 & OGS & 1.21 & 0.00 & 0.00 & 0.00 \\
\hline $\mathrm{Coe}$ & 2004 & USFS & 1.20 & 2.64 & -0.02 & 0.02 \\
\hline Collier & 1910 & McDonald, 1995 & 1.81 & - & - & - \\
\hline Collier & 1933 & McDonald, 1995 & 1.21 & - & - & - \\
\hline Collier & 1935 & McDonald, 1995 & 1.06 & - & - & - \\
\hline Collier & 1938 & McDonald, 1995 & 1.00 & - & - & - \\
\hline Collier & 1941 & McDonald, 1995 & 0.87 & - & - & - \\
\hline Collier & 1949 & McDonald, 1995 & 0.91 & - & - & - \\
\hline Collier & 1957 & USGS & 0.84 & - & - & - \\
\hline Collier & 1967 & USFS & 0.69 & - & - & - \\
\hline Collier & 1973 & USFS & 0.68 & - & - & - \\
\hline Collier & 1982 & USFS & 0.70 & - & - & - \\
\hline Collier & 1985 & $\begin{array}{l}\text { Drediger and } \\
\text { Kennard, } 1985\end{array}$ & 0.77 & - & - & - \\
\hline Collier & 1994 & OGS & 0.65 & - & - & - \\
\hline Eliot & 1901 & Mazamas & 2.03 & - & -0.19 & 0.13 \\
\hline Eliot & 1907 & USGS & 2.00 & - & -0.18 & 0.16 \\
\hline Eliot & 1924 & USGS & 1.98 & - & -0.18 & 0.18 \\
\hline Eliot & 1935 & Mazamas & 1.95 & - & -0.13 & 0.13 \\
\hline Eliot & 1946 & USFS & 1.91 & 4.77 & -0.04 & 0.04 \\
\hline Eliot & 1956 & USGS & 1.81 & - & -0.13 & 0.13 \\
\hline Eliot & 1959 & USFS & 1.84 & 3.55 & -0.03 & 0.03 \\
\hline Eliot & 1967 & USFS & 1.87 & 7.85 & -0.07 & 0.07 \\
\hline Eliot & 1972 & USFS & 1.89 & 5.06 & -0.05 & 0.05 \\
\hline Eliot & 1979 & USFS & 1.80 & 4.29 & -0.04 & 0.04 \\
\hline Eliot & 1984 & USFS & 1.80 & 6.83 & -0.06 & 0.06 \\
\hline Eliot & 1989 & USFS & 1.77 & 9.59 & -0.08 & 0.08 \\
\hline Eliot & 1995 & USFS & 1.78 & 5.10 & -0.04 & 0.04 \\
\hline Eliot & 2000 & OGS & 1.66 & 0.00 & 0.00 & 0.00 \\
\hline Eliot & 2004 & USFS & 1.64 & 5.07 & -0.05 & 0.05 \\
\hline
\end{tabular}




\begin{tabular}{|c|c|c|c|c|c|c|}
\hline Glacier & Year & Source & $\begin{array}{c}\text { Area } \\
\left(\mathrm{km}^{2}\right)\end{array}$ & $\begin{array}{c}\text { RMSE } \\
\text { (m) }\end{array}$ & $\begin{array}{c}\text { Inward } \\
\text { Error } \\
\left(\mathrm{km}^{2}\right)\end{array}$ & $\begin{array}{r}\text { Outward } \\
\text { Error } \\
\left(\mathrm{km}^{2}\right)\end{array}$ \\
\hline Ladd & 1907 & USGS & 1.07 & - & -0.14 & 0.07 \\
\hline Ladd & 1924 & USGS & 1.06 & - & -0.13 & 0.07 \\
\hline Ladd & 1946 & USFS & 0.97 & 7.42 & -0.05 & 0.05 \\
\hline Ladd & 1956 & USGS & 0.94 & - & -0.11 & 0.05 \\
\hline Ladd & 1972 & USFS & 0.81 & 9.73 & -0.05 & 0.05 \\
\hline Ladd & 1989 & USFS & 0.77 & 6.67 & -0.04 & 0.04 \\
\hline Ladd & 2000 & OGS & 0.71 & 0.00 & 0.00 & 0.00 \\
\hline Ladd & 2004 & USFS & 0.67 & 7.92 & -0.05 & 0.05 \\
\hline Newton Clark & 1907 & USGS & 2.06 & - & -0.15 & 0.15 \\
\hline Newton Clark & 1935 & Mazamas & 1.70 & - & -0.08 & 0.08 \\
\hline Newton Clark & 1956 & USGS & 1.66 & - & -0.09 & 0.09 \\
\hline Newton Clark & 1972 & USFS & 1.61 & - & -0.09 & 0.09 \\
\hline Newton Clark & 1984 & USFS & 1.56 & - & -0.09 & 0.09 \\
\hline Newton Clark & 2000 & OGS & 1.54 & 0.00 & 0.00 & 0.00 \\
\hline Newton Clark & 2004 & USFS & 1.40 & - & -0.15 & 0.13 \\
\hline Reid & 1907 & USGS & 0.79 & - & -0.13 & 0.12 \\
\hline Reid & 1935 & Mazamas & 0.64 & - & -0.08 & 0.08 \\
\hline Reid & 1946 & USFS & 0.53 & 6.30 & -0.02 & 0.02 \\
\hline Reid & 1972 & USFS & 0.56 & 8.00 & -0.03 & 0.03 \\
\hline Reid & 1984 & USFS & 0.53 & 8.40 & -0.03 & 0.03 \\
\hline Reid & 2000 & OGS & 0.53 & 0.00 & 0.00 & 0.00 \\
\hline Reid & 2004 & USFS & 0.51 & 13.70 & -0.05 & 0.05 \\
\hline Sandy & 1907 & USGS & 1.61 & - & -0.17 & 0.17 \\
\hline Sandy & 1946 & USFS & 0.99 & 9.60 & -0.07 & 0.07 \\
\hline Sandy & 1972 & USFS & 1.12 & 14.10 & -0.11 & 0.11 \\
\hline Sandy & 2000 & OGS & 1.02 & 0.00 & 0.00 & 0.00 \\
\hline Sandy & 2004 & USFS & 0.96 & 13.85 & -0.15 & 0.13 \\
\hline White River & 1907 & USGS & 1.04 & - & -0.12 & 0.09 \\
\hline White River & 1935 & Mazamas & 0.56 & - & -0.07 & 0.07 \\
\hline White River & 1946 & USFS & 0.47 & 9.51 & -0.04 & 0.04 \\
\hline White River & 1956 & USGS & 0.65 & - & -0.07 & 0.07 \\
\hline White River & 1972 & USFS & 0.59 & 12.28 & -0.06 & 0.06 \\
\hline White River & 1984 & USFS & 0.51 & 11.54 & -0.05 & 0.05 \\
\hline White River & 2000 & OGS & 0.42 & 0.00 & 0.00 & 0.00 \\
\hline White River & 2004 & USFS & 0.41 & 6.86 & -0.03 & 0.03 \\
\hline
\end{tabular}


Appendix B. Four H.F. Reid photographs (courtesy Mazamas, Portland, Oregon) used to estimate glacier surface elevation in 1901. All photographs were taken on July 23, 1901.
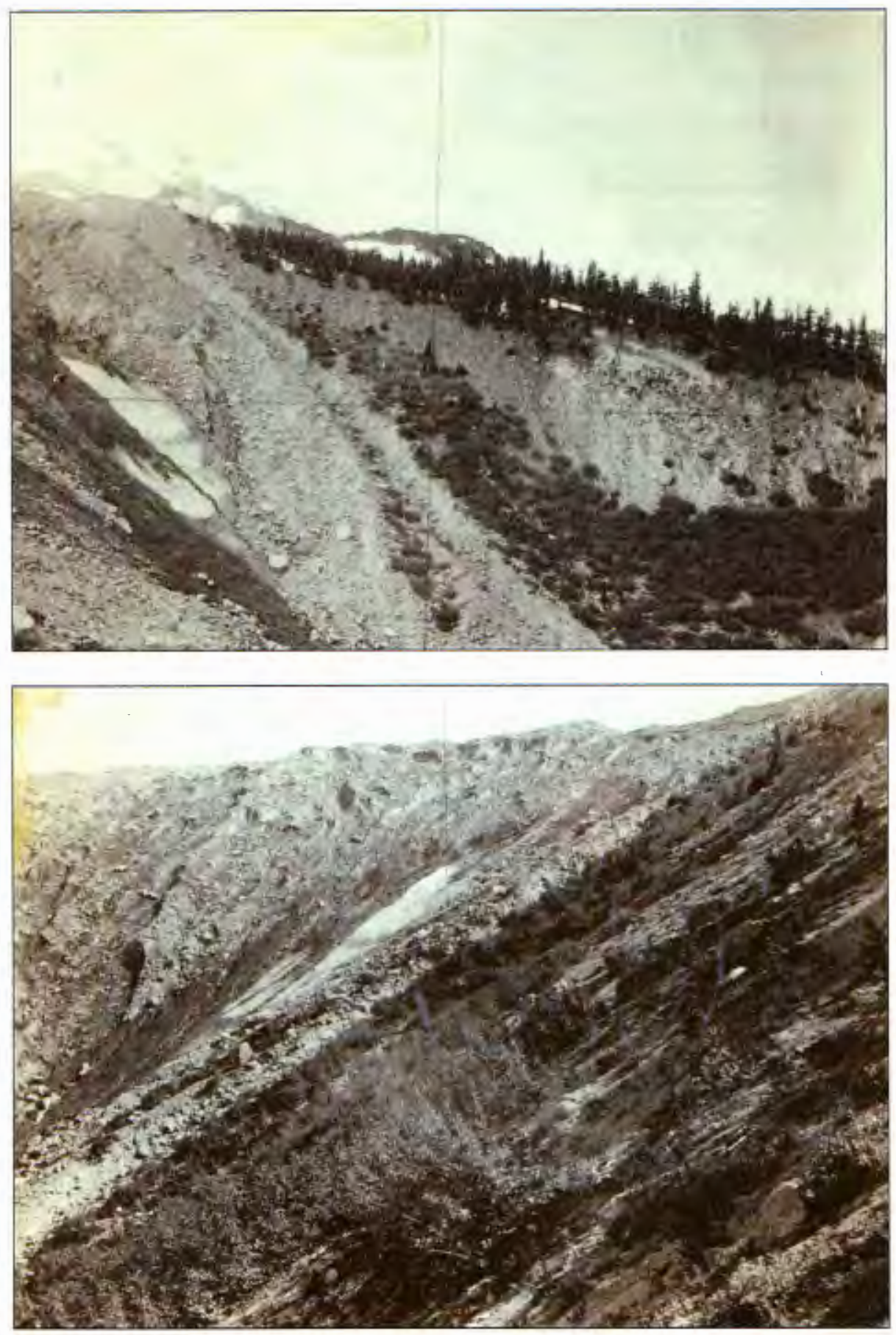

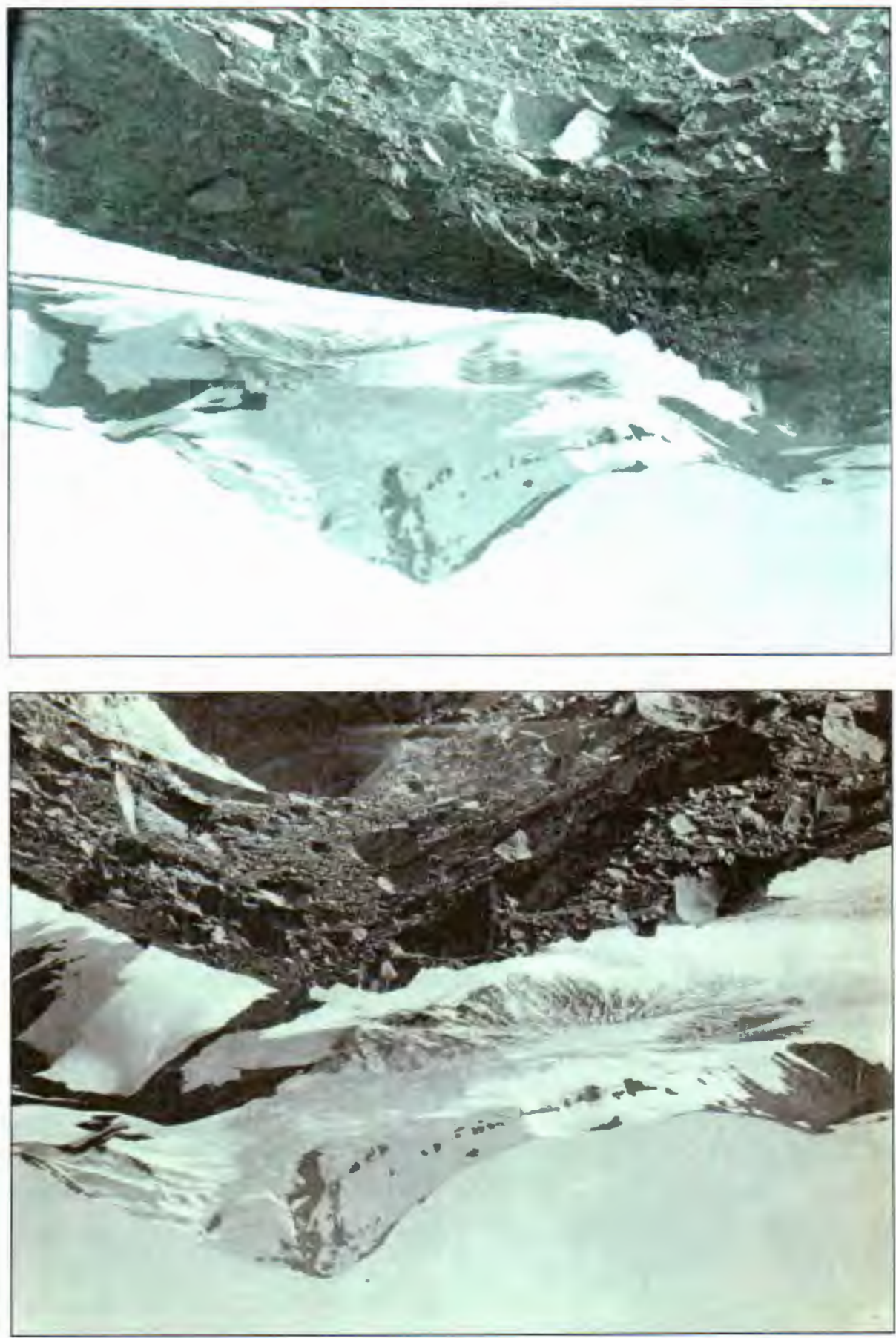
Appendix C. Compilation of debris cover thickness data. Coordinates are UTM NAD 27.

Debris Thickness (m)

0.00

0.00

0.00

0.00

0.00

0.00

0.00

0.01

0.01

0.01

0.01

0.01

0.01

0.02

0.02

0.02

0.03

0.03

0.04

0.04

0.05

0.06

0.06

0.06

0.06

0.06

0.07

0.07

0.08

0.08

0.08

0.09

0.10

0.10

0.10

0.10

0.10

0.11

0.12

0.12

0.13

0.14
Easting Northing

$604166 \quad 5026650$

$604040 \quad 5026570$

604021

5026580

$604069 \quad 5026550$

$604119 \quad 5026600$

$604155 \quad 5026790$

604075

604188

604134

604052

604302

604138

604140

604269

604176

604159

604325

604343

604189

604176

604222

604382

604329

604213

604246

604311

604486

604244

604319

604265

604246

604342

604213

604291

604210

604462

604551

604251

604414

604184

604265

604222

5026700

Debris

Thickness (m) Easting Northing

\begin{tabular}{lll}
\hline 0.26 & 604043 & 5026720
\end{tabular}

$\begin{array}{lll}0.26 & 604350 & 5027020\end{array}$

$\begin{array}{lll}0.26 & 604435 & 5026980\end{array}$

$\begin{array}{lll}0.27 & 604383 & 5027110\end{array}$

$\begin{array}{lll}0.27 & 604369 & 5026790\end{array}$

$\begin{array}{lll}0.28 & 604324 & 5026980\end{array}$

$\begin{array}{lll}0.29 & 604417 & 5027080\end{array}$

$\begin{array}{lll}0.29 & 604433 & 5027060\end{array}$

$\begin{array}{lll}0.29 & 604339 & 5026690\end{array}$

$\begin{array}{lll}0.32 & 604516 & 5027200\end{array}$

$\begin{array}{lll}0.33 & 604106 \quad 5026770\end{array}$

$\begin{array}{lll}0.34 & 604521 & 5026980\end{array}$

$\begin{array}{lll}0.34 & 604410 & 5026910\end{array}$

$\begin{array}{lll}0.35 & 604448 & 5026780\end{array}$

$\begin{array}{lll}0.36 & 604365 & 5027130\end{array}$

$\begin{array}{lll}0.36 & 604597 & 5027160\end{array}$

$\begin{array}{lll}0.38 & 604549 & 5026870\end{array}$

$\begin{array}{lll}0.38 & 604497 & 5026850\end{array}$

$\begin{array}{lll}0.38 & 604380 & 5026760\end{array}$

$\begin{array}{lll}0.39 & 604436 & 5026880\end{array}$

$\begin{array}{lll}0.40 & 604336 & 5027140\end{array}$

$\begin{array}{lll}0.40 & 604307 & 5027120\end{array}$

$\begin{array}{lll}0.41 & 604337 & 5026620\end{array}$

$\begin{array}{lll}0.42 & 604517 & 5026900\end{array}$

$\begin{array}{lll}0.43 & 604221 & 5026910\end{array}$

$\begin{array}{lll}0.44 & 604510 \quad 5027100\end{array}$

$\begin{array}{lll}0.44 & 604653 & 5027200\end{array}$

$\begin{array}{lll}0.46 & 604555 & 5027170\end{array}$

$\begin{array}{lll}0.47 & 604605 & 5027210\end{array}$

$\begin{array}{lll}0.49 & 604464 & 5026870\end{array}$

$\begin{array}{lll}0.49 & 604398 & 5026630\end{array}$

$\begin{array}{lll}0.50 & 604579 & 5026940\end{array}$

$\begin{array}{lll}0.50 & 604234 & 5027010\end{array}$

$\begin{array}{lll}0.50 & 604444 & 5026770\end{array}$

$\begin{array}{lll}0.52 & 604554 & 5027120\end{array}$

$\begin{array}{lll}0.53 & 604367 & 5026600\end{array}$

$\begin{array}{lll}0.54 & 604057 & 5026790\end{array}$

$0.55 \quad 604186 \quad 5026970$

$\begin{array}{lll}0.55 & 604373 \quad 5026660\end{array}$

$\begin{array}{lll}0.56 & 604552 & 5026870\end{array}$

$\begin{array}{lll}0.57 & 604539 & 5026840\end{array}$

$\begin{array}{lll}0.58 & 604246 \quad 5027000\end{array}$ 
Debris \begin{tabular}{ccc} 
Thickness (m) & Easting & Northing \\
\hline 0.15 & 604471 & 5027140
\end{tabular}

0.16

0.17

0.18

0.18

0.21

0.21

0.22

0.22

0.22

0.22

0.22

0.23

0.23

0.23

0.24

0.24

0.24

0.25

0.25

0.26

0.26

0.26

0.26

0.26

0.26
Debris

\begin{tabular}{ccc} 
Thickness (m) & Easting & Northing \\
\hline 0.59 & 604100 & 5026800
\end{tabular}

$\begin{array}{lll}0.59 & 604010 \quad 5026740\end{array}$

$\begin{array}{lll}0.60 & 604459 & 5026870\end{array}$

$\begin{array}{lll}0.60 & 604060 \quad 5026830\end{array}$

$\begin{array}{lll}0.60 & 604435 & 5026630\end{array}$

$\begin{array}{lll}0.60 & 604405 & 5026580\end{array}$

$0.60 \quad 604344 \quad 5026550$

$\begin{array}{lll}0.60 & 604561 & 5027260\end{array}$

$\begin{array}{lll}0.62 & 604118 & 5026870\end{array}$

$0.64 \quad 604494 \quad 5026750$

$\begin{array}{lll}0.65 & 604534 & 5026970\end{array}$

$\begin{array}{lll}0.66 & 604455 & 5026720\end{array}$

$\begin{array}{lll}0.66 & 604422 & 5026740\end{array}$

$0.67 \quad 604558 \quad 5026960$

$\begin{array}{lll}0.67 & 604581 & 5027200\end{array}$

$\begin{array}{lll}0.67 & 604707 & 5027290\end{array}$

$\begin{array}{lll}0.70 & 604424 & 5026750\end{array}$

$\begin{array}{lll}0.77 & 604639 & 5027270\end{array}$

$\begin{array}{lll}0.78 & 604636 & 5027270\end{array}$

$\begin{array}{lll}0.80 & 604601 & 5027290\end{array}$

$0.85 \quad 604253 \quad 5026490$

$\begin{array}{lll}0.90 & 604634 & 5027140\end{array}$

$\begin{array}{lll}1.20 & 604688 & 5027320\end{array}$

$\begin{array}{lll}1.25 & 604423 & 5026800\end{array}$

$1.50 \quad 604954 \quad 5027580$ 
Appendix D. Compilation of survey data for elevation profiles.

\begin{tabular}{|c|c|c|c|c|c|}
\hline \multicolumn{3}{|c|}{ A-Profile } & & \multicolumn{2}{|c|}{ B-Profile } \\
\hline & $\begin{array}{c}\text { Horizontal } \\
\text { Distance (m) }\end{array}$ & $\begin{array}{l}\text { Elevation } \\
\text { (m) }\end{array}$ & & $\begin{array}{c}\text { Horizontal } \\
\text { Distance (m) }\end{array}$ & $\begin{array}{l}\text { Elevation } \\
\text { (m) }\end{array}$ \\
\hline \multirow[t]{16}{*}{1940} & 0.0 & 1953.8 & 1940 & 0.0 & 2089.1 \\
\hline & 18.3 & 1947.7 & & 30.5 & 2069.6 \\
\hline & 36.6 & 1937.0 & & 91.4 & 2033.0 \\
\hline & 61.0 & 1935.5 & & 204.2 & 2004.1 \\
\hline & 91.4 & 1926.3 & & 213.4 & 1996.4 \\
\hline & 115.8 & 1923.3 & & 219.5 & 2002.5 \\
\hline & 125.0 & 1918.7 & & 225.6 & 1999.5 \\
\hline & 155.4 & 1918.7 & & 243.8 & 1999.5 \\
\hline & 164.6 & 1915.7 & & 249.9 & 2002.5 \\
\hline & 207.3 & 1923.3 & & 265.2 & 2004.1 \\
\hline & 231.6 & 1923.3 & & 295.7 & 1999.5 \\
\hline & 243.8 & 1924.8 & & 417.6 & 2048.3 \\
\hline & 256.0 & 1924.8 & & 478.5 & 2087.9 \\
\hline & 274.3 & 1935.5 & 1956 & 0.0 & 2089.1 \\
\hline & 292.6 & 1935.5 & & 103.6 & 2017.8 \\
\hline & 313.9 & 1947.4 & & 121.9 & 2014.7 \\
\hline \multirow[t]{13}{*}{1956} & 0.0 & 1953.8 & & 152.4 & 2002.5 \\
\hline & 57.9 & 1935.5 & & 182.9 & 1981.2 \\
\hline & 82.3 & 1926.3 & & 210.3 & 1981.2 \\
\hline & 112.8 & 1917.2 & & 228.6 & 1975.1 \\
\hline & 131.1 & 1911.1 & & 243.8 & 1984.2 \\
\hline & 149.4 & 1911.1 & & 268.2 & 1984.2 \\
\hline & 167.6 & 1909.6 & & 304.8 & 1991.9 \\
\hline & 199.6 & 1912.6 & & 335.3 & 1996.4 \\
\hline & 213.4 & 1915.7 & & 365.8 & 2008.6 \\
\hline & 243.8 & 1917.2 & & 478.5 & 2087.9 \\
\hline & 253.0 & 1917.2 & 1982 & 0.0 & 2089.1 \\
\hline & 271.3 & 1921.8 & & 96.3 & 2027.3 \\
\hline & 313.9 & 1947.4 & & 111.1 & 2031.1 \\
\hline \multirow[t]{10}{*}{1968} & 0.0 & 1953.8 & & 118.8 & 2028.6 \\
\hline & 56.4 & 1929.4 & & 126.1 & 2032.1 \\
\hline & 91.4 & 1921.8 & & 156.8 & 2024.0 \\
\hline & 170.7 & 1906.5 & & 180.1 & 2023.0 \\
\hline & 202.7 & 1911.1 & & 203.0 & 2033.4 \\
\hline & 231.6 & 1912.6 & & 293.7 & 2023.9 \\
\hline & 313.9 & 1947.4 & & 317.5 & 2033.0 \\
\hline & & & & 363.6 & 2026.9 \\
\hline & & & & 379.1 & 2030.8 \\
\hline & & & & 478.5 & 2087.9 \\
\hline
\end{tabular}


A-Profile

\begin{tabular}{rrr} 
& $\begin{array}{c}\text { Horizontal } \\
\text { Distance (m) }\end{array}$ & $\begin{array}{c}\text { Elevation } \\
(\mathbf{m})\end{array}$ \\
\hline 2005 & 0.0 & 1953.8 \\
88.8 & 1903.6 \\
107.0 & 1897.6 \\
131.9 & 1893.5 \\
141.5 & 1893.4 \\
151.8 & 1888.7 \\
168.6 & 1892.2 \\
186.9 & 1891.4 \\
215.7 & 1899.1 \\
242.0 & 1904.2 \\
312.1 & 1944.6 \\
\hline
\end{tabular}

\begin{tabular}{|c|c|c|}
\hline & \multicolumn{2}{|c|}{ B-Profile } \\
\hline & $\begin{array}{c}\text { Horizontal } \\
\text { Distance (m) }\end{array}$ & $\begin{array}{c}\text { Elevation } \\
\text { (m) }\end{array}$ \\
\hline \multirow[t]{19}{*}{2005} & 0.0 & 2086.3 \\
\hline & 102.7 & 2019.6 \\
\hline & 124.2 & 2014.5 \\
\hline & 146.3 & 2014.9 \\
\hline & 166.2 & 2007.6 \\
\hline & 188.8 & 2003.4 \\
\hline & 212.5 & 2004.3 \\
\hline & 233.6 & 2004.9 \\
\hline & 257.0 & 2007.0 \\
\hline & 280.9 & 2007.0 \\
\hline & 304.6 & 2008.0 \\
\hline & 331.6 & 2004.5 \\
\hline & 350.2 & 2009.5 \\
\hline & 371.3 & 2013.3 \\
\hline & 382.6 & 2021.4 \\
\hline & 392.8 & 2028.2 \\
\hline & 396.0 & 2027.3 \\
\hline & 429.4 & 2049.4 \\
\hline & 482.5 & 2087.0 \\
\hline \multirow[t]{15}{*}{ Bottom } & 102.7 & 2019.6 \\
\hline & 124.2 & 1994.6 \\
\hline & 146.3 & 1986.7 \\
\hline & 166.2 & 1969.1 \\
\hline & 188.8 & 1956.1 \\
\hline & 212.5 & 1953.2 \\
\hline & 233.6 & 1951.9 \\
\hline & 257.0 & 1955.4 \\
\hline & 280.9 & 1956.0 \\
\hline & 304.6 & 1958.3 \\
\hline & 331.6 & 1963.5 \\
\hline & 350.2 & 1982.3 \\
\hline & 371.3 & 1999.9 \\
\hline & 382.6 & 2016.0 \\
\hline & 392.8 & 2028.2 \\
\hline
\end{tabular}


Appendix E. Compilation of GPR data presented in Figure 23.

Easting Northing Ice Thickness (m) Easting Northing Ice Thickness (m)

\begin{tabular}{|c|c|c|c|c|c|}
\hline 604332 & 5026725 & 77.2 & 604413 & 5026958 & 56.1 \\
\hline 604304 & 5026736 & 77.2 & 604450 & 5026955 & 58.6 \\
\hline 604278 & 5026745 & 81.6 & 604490 & 5026954 & 65.8 \\
\hline 604261 & 5026753 & 83.3 & 604527 & 5026953 & 56.3 \\
\hline 604235 & 5026766 & 90.0 & 604558 & 5026950 & 34.6 \\
\hline 604203 & 5026782 & 77.9 & 604494 & 5027034 & 58.3 \\
\hline 604276 & 5026783 & 83.5 & 604485 & 5027053 & 56.1 \\
\hline 604306 & 5026782 & 86.5 & 604477 & 5027070 & 55.0 \\
\hline 604336 & 5026779 & 79.1 & 604469 & 5027094 & 54.6 \\
\hline 604352 & 5026783 & 77.1 & 604454 & 5027129 & 50.2 \\
\hline 604374 & 5026784 & 74.2 & 604503 & 5027123 & 48.3 \\
\hline 604409 & 5026784 & 75.2 & 604538 & 5027134 & 52.7 \\
\hline 604437 & 5026779 & 69.1 & 604571 & 5027147 & 56.2 \\
\hline 604370 & 5026836 & 75.4 & 604600 & 5027167 & 53.7 \\
\hline 604357 & 5026849 & 75.2 & 604612 & 5027195 & 49.5 \\
\hline 604346 & 5026876 & 69.6 & 604639 & 5027208 & 48.5 \\
\hline 604339 & 5026895 & 65.9 & 604656 & 5027217 & 47.1 \\
\hline 604325 & 5026939 & 64.4 & 604672 & 5027238 & 45.8 \\
\hline 604312 & 5026974 & 70.6 & 604699 & 5027255 & 43.2 \\
\hline 604300 & 5027000 & 67.4 & 604720 & 5027273 & 38.0 \\
\hline 604355 & 5026960 & 68.4 & 604735 & 5027284 & 39.0 \\
\hline 604384 & 5026960 & 60.4 & 604758 & 5027301 & 34.6 \\
\hline
\end{tabular}


Appendix F. Compilation of data for velocity surveys. Easting and northing values are UTM NAD 27.

Stake 12

\begin{tabular}{lccccr}
\cline { 1 - 1 } Date & Easting & Northing & Elev. (m asl) & $\begin{array}{c}\text { Horiz. Error } \\
(\mathbf{m})\end{array}$ & $\begin{array}{r}\text { Vert. Error } \\
(\mathbf{m})\end{array}$ \\
\hline 8.13 .2004 & 604168.533 & 5026642.056 & 2100.791 & - & - \\
8.19 .2004 & 604168.582 & 5026642.212 & 2100.937 & 0.001 & - \\
8.27 .2004 & 604168.737 & 5026642.442 & 2100.860 & 0.029 & - \\
9.03 .2004 & 604168.707 & 5026642.636 & 2100.874 & 0.004 & - \\
9.10 .2004 & 604168.786 & 5026642.785 & 2100.799 & 0.001 & - \\
9.24 .2004 & 604168.902 & 5026643.164 & 2100.683 & 0.002 & - \\
7.28 .2005 & 604171.801 & 5026648.832 & 2099.746 & 0.015 & 0.004
\end{tabular}

Stake 11

\begin{tabular}{lccccr}
\cline { 1 - 1 } Date & Easting & Northing & Elev. (m asl) & $\begin{array}{c}\text { Horiz. Error } \\
(\mathbf{m})\end{array}$ & $\begin{array}{r}\text { Vert. Error } \\
(\mathbf{m})\end{array}$ \\
\hline 8.13 .2004 & 604248.230 & 5026734.809 & 2083.994 & - & - \\
8.19 .2004 & 604248.389 & 5026734.903 & 2084.006 & 0.002 & - \\
8.27 .2004 & 604248.611 & 5026735.138 & 2084.016 & 0.022 & - \\
9.03 .2004 & 604248.630 & 5026735.291 & 2083.972 & 0.007 & - \\
9.10 .2004 & 604248.721 & 5026735.444 & 2083.901 & 0.001 & - \\
9.24 .2004 & 604248.806 & 5026735.755 & 2083.865 & 0.000 & - \\
7.28 .2005 & 604250.688 & 5026741.290 & 2081.681 & 0.007 & 0.000
\end{tabular}

Stake 10

\begin{tabular}{lccccr}
\cline { 1 - 1 } Date & Easting & Northing & Elev. (m asl) & $\begin{array}{c}\text { Horiz. Error } \\
(\mathbf{m})\end{array}$ & $\begin{array}{r}\text { Vert. Error } \\
(\mathbf{m})\end{array}$ \\
\hline 8.13 .2004 & 604312.782 & 5026822.335 & 2062.106 & - & - \\
8.19 .2004 & 604312.791 & 5026822.377 & 2062.116 & 0.004 & - \\
8.27 .2004 & 604312.898 & 5026822.491 & 2062.072 & 0.014 & - \\
9.03 .2004 & 604312.938 & 5026822.615 & 2062.102 & 0.015 & - \\
9.10 .2004 & 604312.987 & 5026822.732 & 2062.046 & 0.002 & - \\
9.24 .2004 & 604313.013 & 5026822.913 & 2062.032 & 0.005 & - \\
7.28 .2005 & 604314.945 & 5026827.533 & 2061.166 & 0.004 & 0.001
\end{tabular}

Stake 10A

\begin{tabular}{lccccr}
\hline Date & Easting & Northing & Elev. (m asl) & $\begin{array}{c}\text { Horiz. Error } \\
(\mathbf{m})\end{array}$ & $\begin{array}{r}\text { Vert. Error } \\
(\mathbf{m})\end{array}$ \\
\hline 8.13 .2004 & 604222.899 & 5026904.527 & 2054.095 & - & - \\
8.19 .2004 & 604222.888 & 5026904.629 & 2054.118 & 0.004 & - \\
8.27 .2004 & 604222.986 & 5026904.755 & 2054.150 & 0.020 & - \\
9.03 .2004 & 604223.017 & 5026904.844 & 2054.205 & 0.019 & - \\
9.10 .2004 & 604223.031 & 5026904.939 & 2054.166 & 0.003 & - \\
9.24 .2004 & 604223.038 & 5026905.144 & 2054.197 & 0.008 & - \\
7.28 .2005 & 604224.328 & 5026908.034 & 2054.665 & 0.007 & 0.003
\end{tabular}




\begin{tabular}{lccccr} 
Date & Easting & Northing & Elev. (m asl) & $\begin{array}{c}\text { Horiz. Error } \\
(\mathbf{m})\end{array}$ & $\begin{array}{r}\text { Vert. Error } \\
(\mathbf{m})\end{array}$ \\
\hline 8.13 .2004 & 604253.468 & 5026863.556 & 2063.630 & - & - \\
8.19 .2004 & 604253.498 & 5026863.849 & 2063.673 & 0.004 & - \\
8.27 .2004 & 604253.608 & 5026864.051 & 2063.683 & 0.020 & - \\
9.03 .2004 & 604253.618 & 5026864.117 & 2063.705 & 0.016 & - \\
9.10 .2004 & 604253.685 & 5026864.198 & 2063.659 & 0.002 & - \\
9.24 .2004 & 604253.726 & 5026864.495 & 2063.697 & 0.006 & - \\
7.28 .2005 & 604255.294 & 5026868.046 & 2063.729 & 0.007 & 0.002
\end{tabular}

\section{Stake 10C}

\begin{tabular}{lccccr}
\cline { 1 - 1 } Date & Easting & Northing & Elev. (m asl) & $\begin{array}{c}\text { Horiz. Error } \\
(\mathbf{m})\end{array}$ & $\begin{array}{r}\text { Vert. Error } \\
(\mathbf{m})\end{array}$ \\
\hline 8.13 .2004 & 604370.944 & 5026791.100 & 2066.337 & - & - \\
8.19 .2004 & 604370.937 & 5026791.214 & 2066.335 & 0.003 & - \\
8.27 .2004 & 604371.012 & 5026791.452 & 2066.315 & 0.011 & - \\
9.03 .2004 & 604371.011 & 5026791.708 & 2066.304 & 0.010 & - \\
9.10 .2004 & 604371.012 & 5026791.686 & 2066.252 & 0.001 & - \\
9.24 .2004 & 604371.072 & 5026791.811 & 2066.199 & 0.003 & - \\
7.28 .2005 & 604372.511 & 5026794.885 & 2065.925 & 0.003 & 0.001
\end{tabular}

Stake 10D

\begin{tabular}{lccccr}
\cline { 1 - 1 } Date & Easting & Northing & Elev. (m asl) & $\begin{array}{c}\text { Horiz. Error } \\
(\mathbf{m})\end{array}$ & $\begin{array}{r}\text { Vert. Error } \\
(\mathbf{m})\end{array}$ \\
\hline 8.13 .2004 & 604426.600 & 5026751.185 & 2071.155 & - & - \\
8.19 .2004 & 604426.597 & 5026751.240 & 2071.194 & 0.003 & - \\
8.27 .2004 & 604426.677 & 5026751.365 & 2071.164 & 0.007 & - \\
9.03 .2004 & 604426.681 & 5026751.512 & 2071.178 & 0.014 & - \\
9.10 .2004 & 604426.690 & 5026751.569 & 2071.112 & 0.002 & - \\
9.24 .2004 & 604426.732 & 5026751.754 & 2071.076 & 0.005 & - \\
7.28 .2005 & 604427.932 & 5026754.408 & 2070.491 & 0.002 & 0.000
\end{tabular}

Stake 9

\begin{tabular}{lccccr}
\cline { 1 - 1 } Date & Easting & Northing & Elev. (m asl) & $\begin{array}{c}\text { Horiz. Error } \\
(\mathbf{m})\end{array}$ & $\begin{array}{r}\text { Vert. Error } \\
(\mathbf{m})\end{array}$ \\
\hline 8.13 .2004 & 604379.041 & 5026894.672 & 2042.363 & - & - \\
8.19 .2004 & 604379.041 & 5026894.922 & 2042.368 & 0.003 & - \\
8.27 .2004 & 604379.089 & 5026894.980 & 2042.366 & 0.021 & - \\
9.03 .2004 & 604379.125 & 5026895.066 & 2042.400 & 0.017 & - \\
9.10 .2004 & 604379.131 & 5026895.071 & 2042.376 & 0.002 & - \\
9.24 .2004 & 604379.122 & 5026895.193 & 2042.379 & 0.007 & - \\
7.28 .2005 & 604380.507 & 5026898.126 & 2042.460 & 0.010 & 0.004
\end{tabular}

Stake 8

\begin{tabular}{lccccr}
\hline Date & Easting & Northing & Elev. (m asl) & $\begin{array}{c}\text { Horiz. Error } \\
(\mathbf{m})\end{array}$ & $\begin{array}{r}\text { Vert. Error } \\
(\mathbf{m})\end{array}$ \\
\hline 8.13 .2004 & 604436.925 & 5026973.779 & 2019.682 & - & - \\
8.19 .2004 & 604436.895 & 5026973.838 & 2019.707 & 0.001 & -
\end{tabular}




$\begin{array}{llllll}8.27 .2004 & 604436.952 & 5026973.986 & 2019.695 & 0.015 & - \\ 9.03 .2004 & 604437.016 & 5026974.057 & 2019.729 & 0.021 & - \\ 9.10 .2004 & 604436.972 & 5026974.162 & 2019.690 & 0.003 & - \\ 9.24 .2004 & 604436.995 & 5026974.243 & 2019.697 & 0.009 & - \\ 7.28 .2005 & 604438.122 & 5026976.740 & 2019.612 & 0.012 & 0.006\end{array}$

\section{Boulder 8A}

\begin{tabular}{lccccr}
\hline Date & Easting & Northing & Elev.(m asl) & $\begin{array}{r}\text { Horiz. Error } \\
(\mathbf{m})\end{array}$ & $\begin{array}{r}\text { Vert. Error } \\
(\mathbf{m})\end{array}$ \\
\hline 8.13 .2004 & - & - & - & - & - \\
8.19 .2004 & 604377.900 & 5027011.248 & 2022.073 & 0.002 & - \\
8.27 .2004 & 604378.003 & 5027011.312 & 2022.009 & 0.011 & - \\
9.03 .2004 & 604378.099 & 5027011.322 & 2022.001 & 0.015 & - \\
9.10 .2004 & 604378.141 & 5027011.404 & 2021.904 & 0.002 & - \\
9.24 .2004 & 604378.166 & 5027011.498 & 2021.792 & 0.006 & - \\
7.28 .2005 & 604379.737 & 5027013.290 & 2021.271 & 0.008 & 0.007
\end{tabular}

\section{Boulder 8B}

\begin{tabular}{lccccr}
\cline { 1 - 1 } Date & Easting & Northing & Elev. (m asl) & $\begin{array}{c}\text { Horiz. Error } \\
(\mathbf{m})\end{array}$ & $\begin{array}{r}\text { Vert. Error } \\
(\mathbf{m})\end{array}$ \\
\hline 8.13 .2004 & - & - & - & - & - \\
8.19 .2004 & 604474.278 & 5026952.861 & 2028.697 & 0.001 & - \\
8.27 .2004 & 604474.369 & 5026952.994 & 2028.596 & 0.018 & - \\
9.03 .2004 & 604474.461 & 5026953.115 & 2028.557 & 0.026 & - \\
9.10 .2004 & 604474.403 & 5026953.179 & 2028.434 & 0.003 & - \\
9.24 .2004 & 604474.419 & 5026953.312 & 2028.340 & 0.011 & - \\
7.28 .2005 & 604475.302 & 5026956.104 & 2027.382 & 0.012 & 0.006
\end{tabular}

\section{Stake 7}

\begin{tabular}{lccccr}
\cline { 1 - 1 } Date & Easting & Northing & Elev. (m asl) & $\begin{array}{c}\text { Horiz. Error } \\
(\mathbf{m})\end{array}$ & $\begin{array}{r}\text { Vert. Error } \\
(\mathbf{m})\end{array}$ \\
\hline 8.13 .2004 & 604482.666 & 5027048.658 & 2002.506 & - & - \\
8.19 .2004 & 604482.626 & 5027048.708 & 2002.516 & 0.001 & - \\
8.27 .2004 & 604482.648 & 5027048.808 & 2002.522 & 0.011 & - \\
9.03 .2004 & 604482.708 & 5027048.838 & 2002.555 & 0.022 & - \\
9.10 .2004 & 604482.667 & 5027048.861 & 2002.517 & 0.003 & - \\
9.24 .2004 & 604482.751 & 5027048.862 & 2002.532 & 0.009 & - \\
7.28 .2005 & 604483.632 & 5027050.604 & 2002.677 & 0.011 & 0.007
\end{tabular}

Stake 6

\begin{tabular}{lccccr}
\cline { 1 - 4 } Date & Easting & Northing & Elev. (m asl) & $\begin{array}{c}\text { Horiz. Error } \\
(\mathbf{m})\end{array}$ & $\begin{array}{r}\text { Vert. Error } \\
(\mathbf{m})\end{array}$ \\
\hline 8.13 .2004 & 604556.154 & 5027117.607 & 1984.675 & - & - \\
8.19 .2004 & 604556.183 & 5027117.643 & 1984.671 & 0.004 & - \\
8.27 .2004 & 604556.169 & 5027117.690 & 1984.650 & 0.011 & - \\
9.03 .2004 & 604556.211 & 5027117.866 & 1984.651 & 0.021 & - \\
9.10 .2004 & 604556.027 & 5027117.995 & 1984.588 & 0.002 & - \\
9.24 .2004 & 604556.113 & 5027117.701 & 1984.640 & 0.031 & -
\end{tabular}


$\begin{array}{llllll}7.28 .2005 & 604556.728 & 5027118.896 & 1984.375 & 0.007 & 0.008\end{array}$

Stake 5

\begin{tabular}{lccccr}
\cline { 1 - 1 } Date & Easting & Northing & Elev. (m asl) & $\begin{array}{c}\text { Horiz. Error } \\
\text { (m) }\end{array}$ & $\begin{array}{r}\text { Vert. Error } \\
\text { (m) }\end{array}$ \\
\hline 8.13 .2004 & 604606.853 & 5027203.181 & 1967.422 & - & - \\
8.19 .2004 & 604606.824 & 5027203.242 & 1967.411 & 0.005 & - \\
8.27 .2004 & 604606.887 & 5027203.235 & 1967.393 & 0.009 & - \\
9.03 .2004 & 604607.053 & 5027203.326 & 1967.418 & 0.033 & - \\
9.10 .2004 & 604606.981 & 5027203.267 & 1967.372 & 0.005 & - \\
9.24 .2004 & 604607.043 & 5027203.235 & 1967.354 & 0.032 & - \\
7.28 .2005 & 604607.854 & 5027204.069 & 1967.054 & 0.003 & 0.010
\end{tabular}

Stake 5A

\begin{tabular}{lccccr}
\cline { 1 - 1 } Date & Easting & Northing & Elev. (m asI) & $\begin{array}{c}\text { Horiz. Error } \\
(\mathbf{m})\end{array}$ & $\begin{array}{r}\text { Vert. Error } \\
(\mathbf{m})\end{array}$ \\
\hline 8.13 .2004 & 604518.454 & 5027201.465 & 1975.357 & - & - \\
8.19 .2004 & 604518.483 & 5027201.533 & 1975.368 & 0.003 & - \\
8.27 .2004 & 604518.542 & 5027201.560 & 1975.354 & 0.008 & - \\
9.03 .2004 & 604518.565 & 5027201.653 & 1975.376 & 0.021 & - \\
9.10 .2004 & 604518.625 & 5027201.661 & 1975.333 & 0.003 & - \\
9.24 .2004 & 604518.682 & 5027201.595 & 1975.338 & 0.023 & - \\
7.28 .2005 & 604519.255 & 5027202.554 & 1975.377 & 0.003 & 0.009
\end{tabular}

Stake 5B

\begin{tabular}{lccccr}
\cline { 1 - 3 } Date & Easting & Northing & Elev. $(\mathbf{m}$ asl) & $\begin{array}{c}\text { Horiz. Error } \\
(\mathbf{m})\end{array}$ & $\begin{array}{r}\text { Vert. Error } \\
(\mathbf{m})\end{array}$ \\
\hline 8.13 .2004 & 604636.441 & 5027141.723 & 1975.123 & - & - \\
8.19 .2004 & 604636.428 & 5027141.751 & 1975.106 & 0.006 & - \\
8.27 .2004 & 604636.493 & 5027141.785 & 1975.120 & 0.011 & - \\
9.03 .2004 & 604636.485 & 5027141.806 & 1975.151 & 0.030 & - \\
9.10 .2004 & 604636.478 & 5027141.772 & 1975.116 & 0.004 & - \\
9.24 .2004 & 604636.472 & 5027141.720 & 1975.110 & 0.038 & - \\
7.28 .2005 & 604636.805 & 5027142.447 & 1975.007 & 0.007 & 0.009
\end{tabular}

Boulder 3

\begin{tabular}{lccccr}
\hline Date & Easting & Northing & Elev. (m asl) & $\begin{array}{c}\text { Horiz. Error } \\
(\mathbf{m})\end{array}$ & $\begin{array}{r}\text { Vert. Error } \\
(\mathbf{m})\end{array}$ \\
\hline 8.13 .2004 & 604687.423 & 5027322.954 & 1937.755 & - & - \\
8.19 .2004 & 604687.423 & 5027323.000 & 1937.874 & 0.007 & - \\
8.27 .2004 & 604687.430 & 5027323.012 & 1937.842 & 0.007 & - \\
9.03 .2004 & 604687.416 & 5027323.088 & 1937.884 & 0.047 & - \\
9.10 .2004 & 604687.471 & 5027322.992 & 1937.836 & 0.008 & - \\
9.24 .2004 & 604687.505 & 5027322.949 & 1937.840 & 0.040 & - \\
7.28 .2005 & 604687.779 & 5027323.556 & 1937.610 & 0.002 & 0.012
\end{tabular}

Boulder 2 
(m)

(m)

\begin{tabular}{llllll}
\hline 8.13 .2004 & 604737.218 & 5027408.052 & 1904.258 & - & - \\
8.19 .2004 & 604737.193 & 5027408.028 & 1904.381 & 0.010 & - \\
8.27 .2004 & 604737.217 & 5027408.038 & 1904.384 & 0.004 & - \\
9.03 .2004 & 604737.192 & 5027408.162 & 1904.414 & 0.062 & - \\
9.10 .2004 & 604737.233 & 5027407.984 & 1904.367 & 0.011 & - \\
9.24 .2004 & 604737.270 & 5027407.900 & 1904.388 & 0.046 & 0.015 \\
7.28 .2005 & 604737.198 & 5027407.956 & 1904.426 & 0.000 &
\end{tabular}

Boulder 2A

\begin{tabular}{lcccccr}
\hline Date & Easting & Northing & Elev. (m asl) & $\begin{array}{c}\text { Horiz. Error } \\
(\mathbf{m})\end{array}$ & $\begin{array}{r}\text { Vert. Error } \\
(\mathbf{m})\end{array}$ \\
\hline 8.13 .2004 & - & - & - & - & - \\
8.19 .2004 & 604892.588 & 5027410.340 & 1929.582 & 0.012 & - \\
8.27 .2004 & 604892.567 & 5027410.394 & 1929.543 & 0.017 & - \\
9.03 .2004 & 604892.526 & 5027410.523 & 1929.553 & 0.089 & - \\
9.10 .2004 & 604892.616 & 5027410.316 & 1929.546 & 0.016 & - \\
9.24 .2004 & 604892.629 & 5027410.256 & 1929.497 & 0.059 & - \\
7.28 .2005 & 604892.476 & 5027410.519 & 1929.274 & 0.003 & 0.013
\end{tabular}

Boulder 1

\begin{tabular}{lccccr}
\hline Date & Easting & Northing & Elev. (m as) & $\begin{array}{c}\text { Horiz. Error } \\
(\mathbf{m})\end{array}$ & $\begin{array}{r}\text { Vert. Error } \\
(\mathbf{m})\end{array}$ \\
\hline 8.13 .2004 & 604797.811 & 5027490.155 & 1897.619 & - & - \\
8.19 .2004 & 604797.810 & 5027490.136 & 1897.725 & 0.013 & - \\
8.27 .2004 & 604797.778 & 5027490.149 & 1897.704 & 0.003 & - \\
9.03 .2004 & 604797.723 & 5027490.288 & 1897.756 & 0.087 & - \\
9.10 .2004 & 604797.821 & 5027490.096 & 1897.705 & 0.016 & - \\
9.24 .2004 & 604797.858 & 5027489.978 & 1897.721 & 0.052 & - \\
7.28 .2005 & 604797.793 & 5027490.094 & 1897.779 & 0.005 & 0.016
\end{tabular}

\section{Boulder 1A}

\begin{tabular}{lccccr}
\cline { 1 - 1 } Date & Easting & Northing & Elev. (m asl) & $\begin{array}{c}\text { Horiz. Error } \\
(\mathbf{m})\end{array}$ & $\begin{array}{r}\text { Vert. Error } \\
(\mathbf{m})\end{array}$ \\
\hline 8.13 .2004 & - & - & - & - & - \\
8.19 .2004 & 604914.480 & 5027508.936 & 1905.928 & 0.015 & - \\
8.27 .2004 & 604914.474 & 5027509.002 & 1905.843 & 0.025 & - \\
9.03 .2004 & 604914.386 & 5027509.159 & 1905.821 & 0.113 & - \\
9.10 .2004 & 604914.480 & 5027508.916 & 1905.752 & 0.022 & - \\
9.24 .2004 & 604914.487 & 5027508.864 & 1905.712 & 0.061 & - \\
7.28 .2005 & 604913.978 & 5027509.360 & 1905.167 & 0.009 & 0.015
\end{tabular}

